\title{
Chapter 17 \\ Rangeland Systems in Developing Nations: \\ Conceptual Advances and Societal Implications
}

\author{
D. Layne Coppock, María Fernández-Giménez, Pierre Hiernaux, \\ Elisabeth Huber-Sannwald, Catherine Schloeder, Corinne Valdivia, \\ José Tulio Arredondo, Michael Jacobs, Cecilia Turin, and Matthew Turner
}

\begin{abstract}
Developing-country rangelands are vast and diverse. They are home to millions who are often poor, politically marginalized, and dependent on livestock for survival. Here we summarize our experiences from six case-study sites in subSaharan Africa, central Asia, and Latin America generally covering the past 25 years. We examine issues pertaining to population, natural resource management, climate, land use, livestock marketing, social conflict, and pastoral livelihoods. The six study sites differ with respect to human and livestock population dynamics and
\end{abstract}

This chapter is dedicated to the memory of an exemplary international rangeland scientist, Thomas L. Thurow (1955-2016).

D.L. Coppock $(\square)$

Department of Environment \& Society, Utah State University, Logan, UT, USA

e-mail: Layne.Coppock@usu.edu

M. Fernández-Giménez

Department of Forest and Rangeland Stewardship, Colorado State University,

Fort Collins, CO, USA

P. Hiernaux

Centre National de la Recherche Scientifique, Géosciences Environnement Toulouse,

Toulouse, France

E. Huber-Sannwald $\bullet$ J.T. Arredondo

Instituto Potosino de Investigación Científica y Tecnológica, San Luis Potosi, Mexico

C. Schloeder • M. Jacobs

Oikos Services LLC, Fortine, MT, USA

C. Valdivia

Department of Agricultural and Applied Economics, University of Missouri,

Columbia, MO, USA

C. Turin

Division of Crop System Intensification and Climate Change, International Potato Center,

Lima, Peru

M. Turner

Department of Geography, University of Wisconsin, Madison, WI, USA 
the resulting pressures on natural resources. Environmental degradation, however, has been commonly observed. Climate change is also having diverse systemic effects often related to increasing aridity. As rangelands become more economically developed pastoral livelihoods may diversify, food security can improve, and commercial livestock production expands, but wealth stratification widens. Some significant upgrades in rural infrastructure and public service delivery have occurred; telecommunications are markedly improved overall due to widespread adoption of mobile phones. Pressures from grazing, farming, mining, and other land usescombined with drought - can ignite local conflicts over resources, although the intensity and scope of conflicts markedly varies across our case-study sites. Pastoralists and their herds have become more sedentary overall due to many factors, and this can undermine traditional risk-management tactics based on mobility. Remote rangelands still offer safe havens for insurgents, warlords, and criminals especially in countries where policing remains weak; the resulting civil strife can undermine commerce and public safety. There has been tremendous growth in knowledge concerning developing-country rangelands since 1990, but this has not often translated into improved environmental stewardship or an enhanced wellbeing for rangeland dwellers. Some examples of demonstrable impact are described, and these typically have involved longer-term investments in capacity building for pastoralists, local professionals, and other stakeholders. Research is shifting from ecologically centered to more human-centered issues; traditional academic approaches are often being augmented with participatory, community-based engagement. Building human or social capital in ways that are integrated with improved natural resource stewardship offers the greatest returns on research investment. Our future research and outreach priorities include work that fortifies pastoral governance, enhances livelihoods for a diverse array of rangeland residents, and improves land and livestock management in a comprehensive social-ecological systems approach.

Keywords Bolivian Altiplano • Ethiopian Boran • Afghan Kuchi • Mexican rangelands $\bullet$ Mongolia $\bullet$ Peruvian Altiplano $\bullet$ Sahel

\subsection{Introduction}

In this chapter we focus on rangelands of the developing world. By rangelands we refer to landscapes - largely unsuitable for sustained cultivation-providing forage, water, and cover for grazing and browsing animals. These landscapes occur in deserts, grasslands, shrublands, savannas, woodlands, and alpine systems [definition modified from Holechek et al. (2011, p. 1)].

"Developing nations" refer to countries having a relatively low standard of living, an underdeveloped industrial base, a low gross domestic product per capita, and a low Human Development Index (Sullivan and Sheffrin 2003). The rangelands of developing nations have endured a wide array of challenges including poverty, environmental 
degradation, social conflicts, displaced people, and climate change (Seré et al. 2008; Thornton et al. 2009). Rangelands collectively represent about $70 \%$ of the world's land surface (Holechek et al. 2011) and are home to 2.1 billion people-35\% of the world's population. ${ }^{1}$ In sum, the rangelands of the developing world greatly matter to anyone who ponders how to improve the human condition or the stewardship of natural resources.

Rangelands of the developing world are also places where major conceptual advances for research and development have occurred over the past 30 years. These advances have affected range science and range management globally and include rangeland production modeling (Penning de Vries and Djiteye 1982), nonequilibrium ecology (Ellis and Swift 1988), resilience theory (Walker 2002), climate change (Olsson et al. 2005), pastoral management of livestock gene pools (Krätli 2007), coupled social-ecological systems (Stafford-Smith et al. 2009), action research and gender (Coppock et al. 2011), and decentralized or community-based natural resource governance (Reid et al. 2015).

The dominant economic use of rangelands in the developing world is livestock production as practiced by pastoralists using communal resources on state-owned or community-owned lands and, to a lesser extent, by producers using resources on privately held lands (Holechek et al. 2011). Other economic uses are on the rise and include dryland farming, hard-rock mining, oil and gas extraction, renewable energy production, recreation, and tourism. Important national parks and protected areas occur in rangelands worldwide (Chape et al. 2008). Developing-country rangelands provide vital global ecosystem goods and services, including carbon sequestration that mitigates effects from greenhouse gas emissions (Safriel et al. 2005). Climate change will affect the use of these landscapes (Feng et al. 2010; Long et al. 2006), as many developing-nation rangelands are projected to become warmer, drier, and subjected to more frequent extreme weather (IPCC 2013; Nicholson 2013; Stahle et al. 2009).

The coauthors of this chapter average over 20 years of experience in the developing world. They have contributed insights related to six case-study sites to capture broad patterns across social-ecological systems in a rangeland-development context. Grouped into two tiers according to a Human Development Index (HDI) calculated for 187 nations and territories (UNDP 2013), the case study sites include a less developed, lower tier with Afghanistan, southern Ethiopia, and the Sahelian belt (subsites in Niger, Mali, and Senegal-henceforth called the Sahel), and a more economically developed upper tier with Mongolia, the high Andes (Bolivia and Peru-henceforth called the Altiplano), and northern Mexico. The first tier has HDI country rankings that vary from 187 (Niger) to 154 (Senegal) while the second-tier HDI rankings range from 108 (Bolivia and Mongolia) to 61 (Mexico). The case study sites are mapped in Fig. 17.1. The sites illustrate wide variation in geographic, biophysical, and socioeconomic attributes. They have been monitored by the same scholars over extended periods of time and thus provide an unusual opportunity for credible long-term assessments, cross-site comparisons, and learning.

\footnotetext{
${ }^{1}$ http://www.un.org/en/events/desertification_decade/whynow.shtml
} 


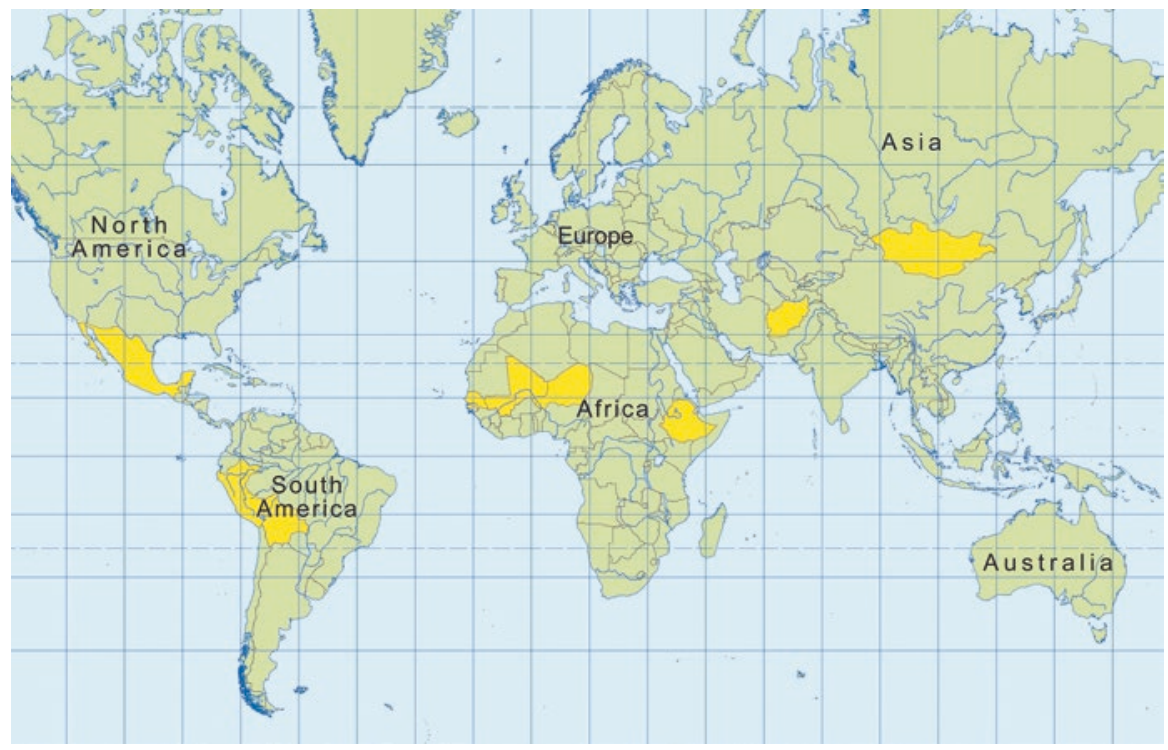

Fig. 17.1 Condensed world map showing nine nations that host the rangeland study sites reviewed in this chapter (illustration courtesy of Publication Design and Production, Utah State University)

\subsection{Global Trends: Rangelands of the Developing World}

Some socioeconomic and agroecological features for the six case study sites are shown in Table 17.1. The ecosystems vary from warm, subtropical savannas to cold, shrub steppe. Economic uses are dominated by extensive livestock production, but variation in the predominant livestock species, livestock products, and livestock population trends is notable. With some exceptions (i.e., Mongolia, Mexico) the rangeland inhabitants largely represent indigenous societies that are economically or socially marginalized within their home countries.

The material that follows in this section combines empirical information from the case study sites with other literature to integrate and describe some commonly observed patterns concerning populations, socioeconomics, and natural resources. Each subsection begins with a concise summary paragraph. Becoming aware of this background is especially important for readers who are less familiar with pastoralism or rangelands. Those who want to skip the background and focus on current conceptual or operational issues can go directly to Sect. 17.3. 


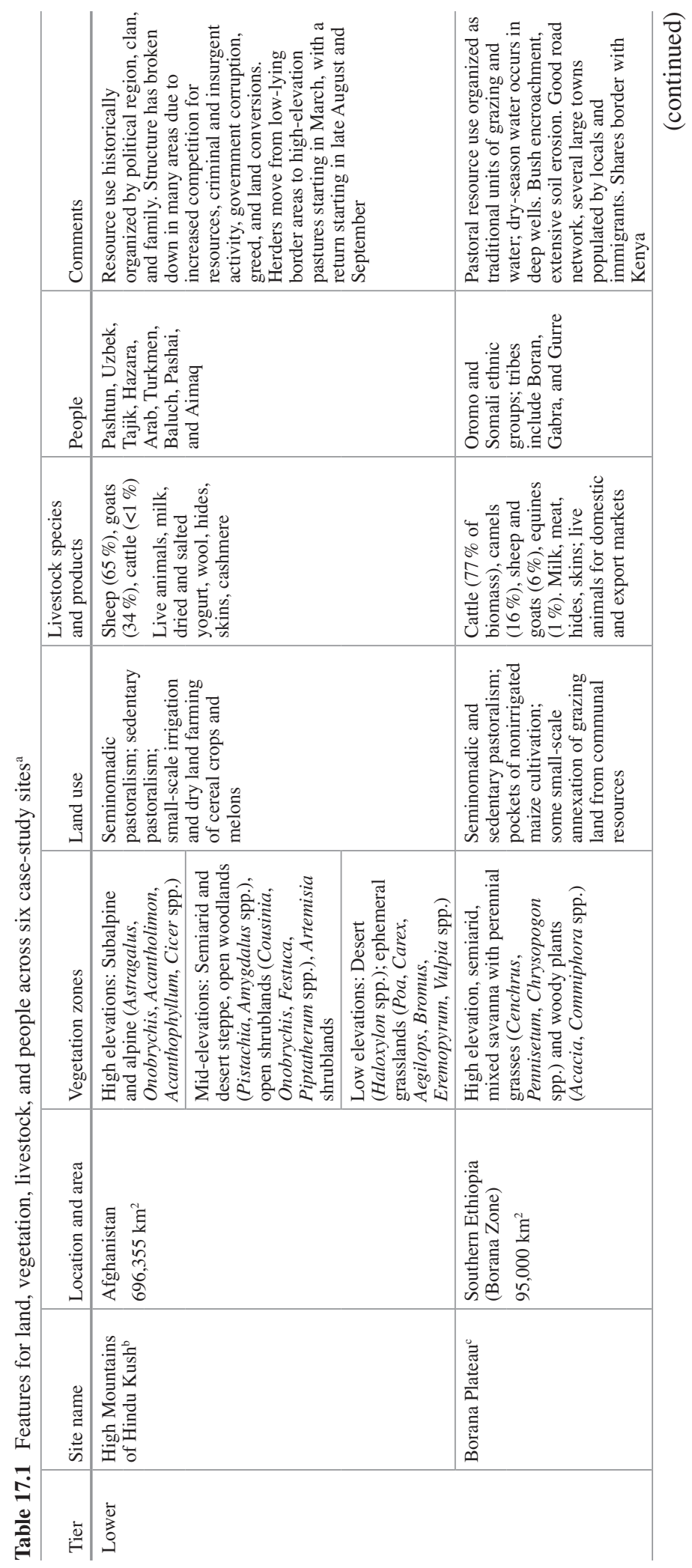




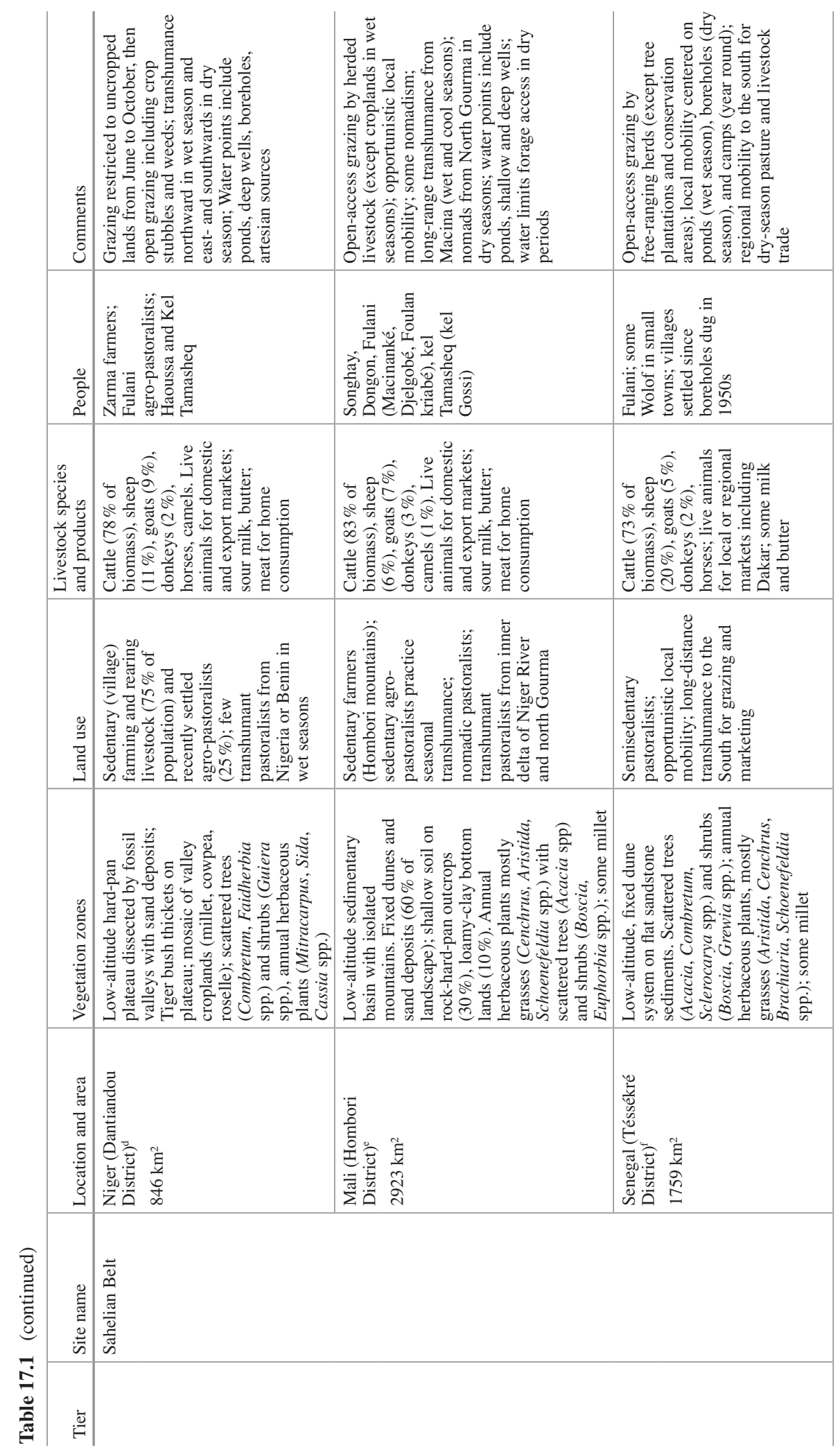




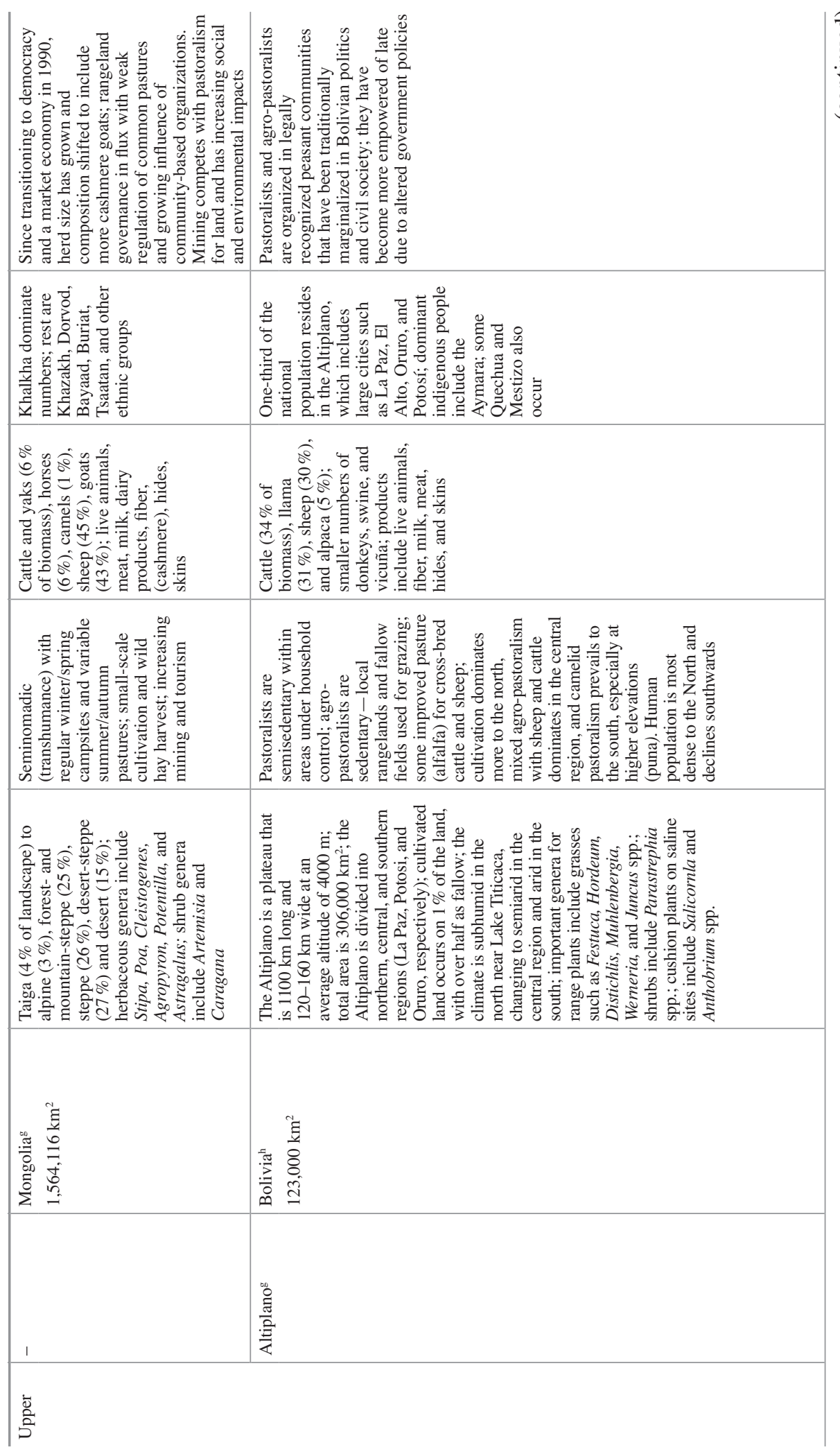




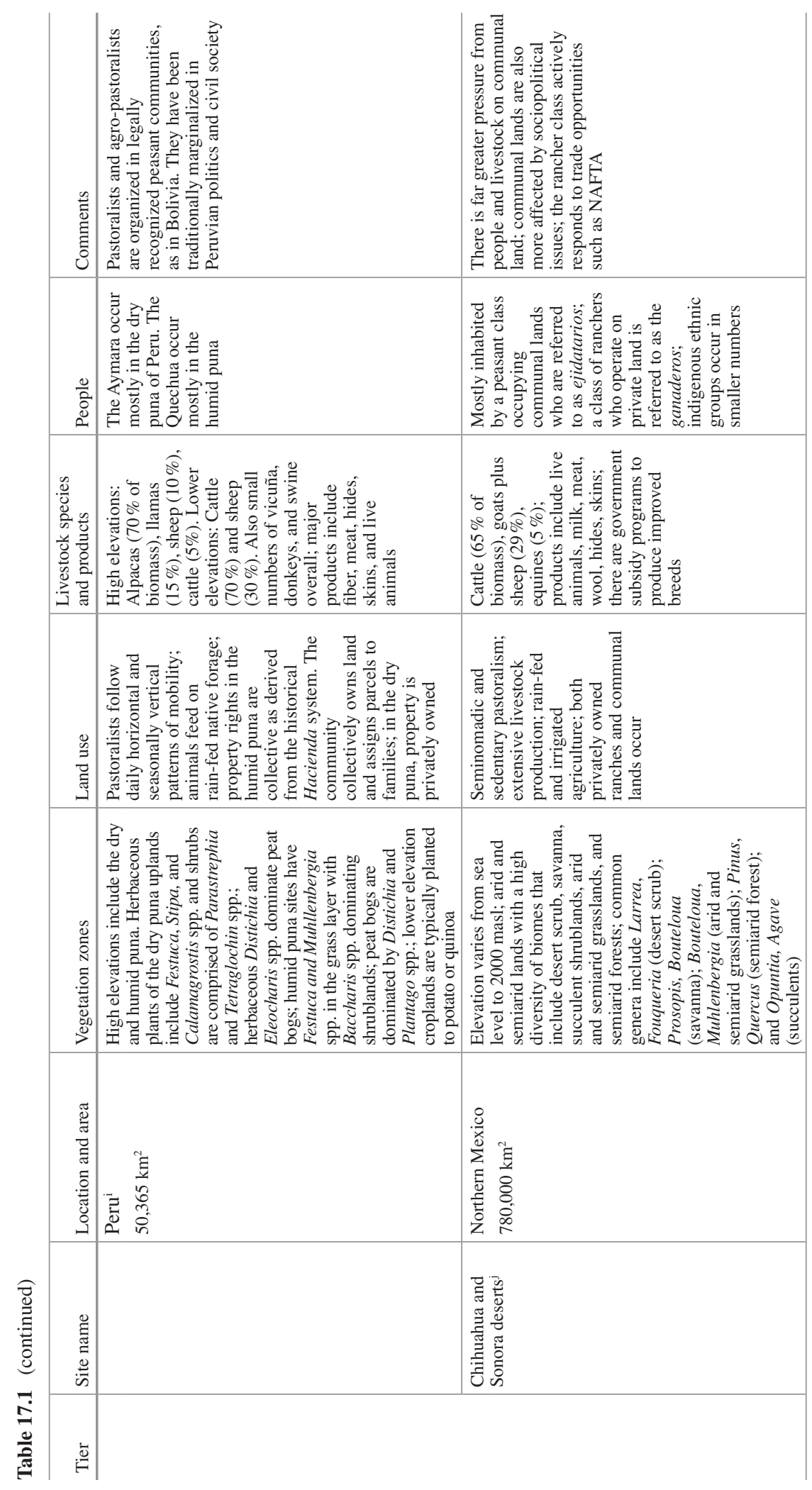




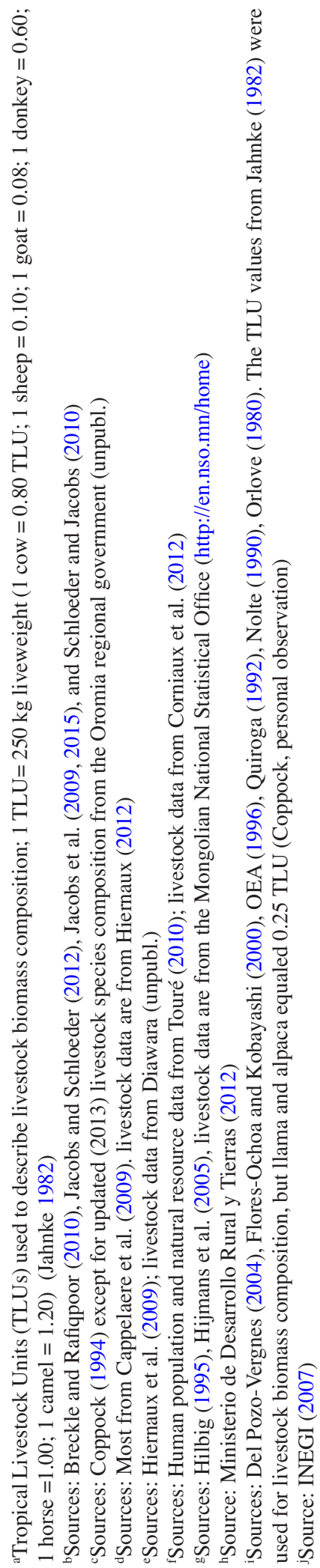




\subsubsection{Human Populations}

Summary. Human population growth is a driver that profoundly affects all ecosystems. Human populations in developing-country rangelands are affected by demographic, ecological, economic, and political forces. Human population densities tend to rise in response to increasing annual precipitation and agricultural productivity as one goes from the arid to semiarid and subhumid zones. As nations or regions become wealthier, however, net human population growth in the rangelands tends to decrease and there are more chances for rangeland dwellers to emigrate in search of employment (typically males). In some of these situations, women can then become the primary stewards of local rangeland resources. Change in economic opportunities can dramatically affect the magnitude and direction of rural-tourban migrations, especially as nations develop. Persistent warfare, poverty, and drought-and even organized crime-can be profoundly disruptive, however, resulting in a depopulation of some rangeland systems.

Human population growth is a driver that strongly influences the use of natural resources and the adoption of new technology in agro-ecosystems (Boserup 1965, 1989). Thus, human population issues merit our review. Images of important rangeland people in our case-study sites are shown in Fig. 17.2a-f. The evidence is mixed concerning human population trends across our six case-study areas. Population densities tend to be higher in agro-pastoral settings compared to pastoral settings because the former produce more food for people per unit area. ${ }^{2}$

Marked net increases in rangeland human populations have been noted for southern Ethiopia and the Sahel. Here increased fertility and decreased child mortality among pastoralists - as well as immigration by outsiders - have contributed to high rates of sustained growth, i.e., from 2 to $3 \%$ per annum. ${ }^{3}$ Emigration from pastoral zones in southern Ethiopia remains low, probably due to low exposure to formal education and lack of wage labor opportunities across the nation (Coppock et al. 2011). In the Sahel, emigration of agro-pastoral men to urban areas seeking wage labor has mitigated some population growth in the rangelands (Guengant et al. 2002; Wane et al. 2010). In contrast to the African examples, the number of Kuchi still using Afghanistan's rangelands is lower today than in the past despite the Kuchi having one of the world's highest fertility rates (e.g., 7.28; NRVA 2008). Reasons for this include high infant mortality rates caused by lack of health care and basic services, sedentarization ${ }^{4}$ resulting from land conversions and resource degradation, recurring drought, social conflict, and chronic food insecurity.

\footnotetext{
${ }^{2}$ Agro-pastoral systems routinely combine crop and livestock production, while pastoral systems focus on livestock production (Jahnke 1982).

${ }^{3}$ Increased fertility and decreased mortality among pastoralists have occurred as a result of many factors. In some cases, development of clean water sources, provision of disease control for both people and livestock, improvements in infrastructure, and provision of food relief can be included. ${ }^{4}$ Defined here as the transition from a nomadic or seminomadic lifestyle to a society that permanently resides in one place.
} 

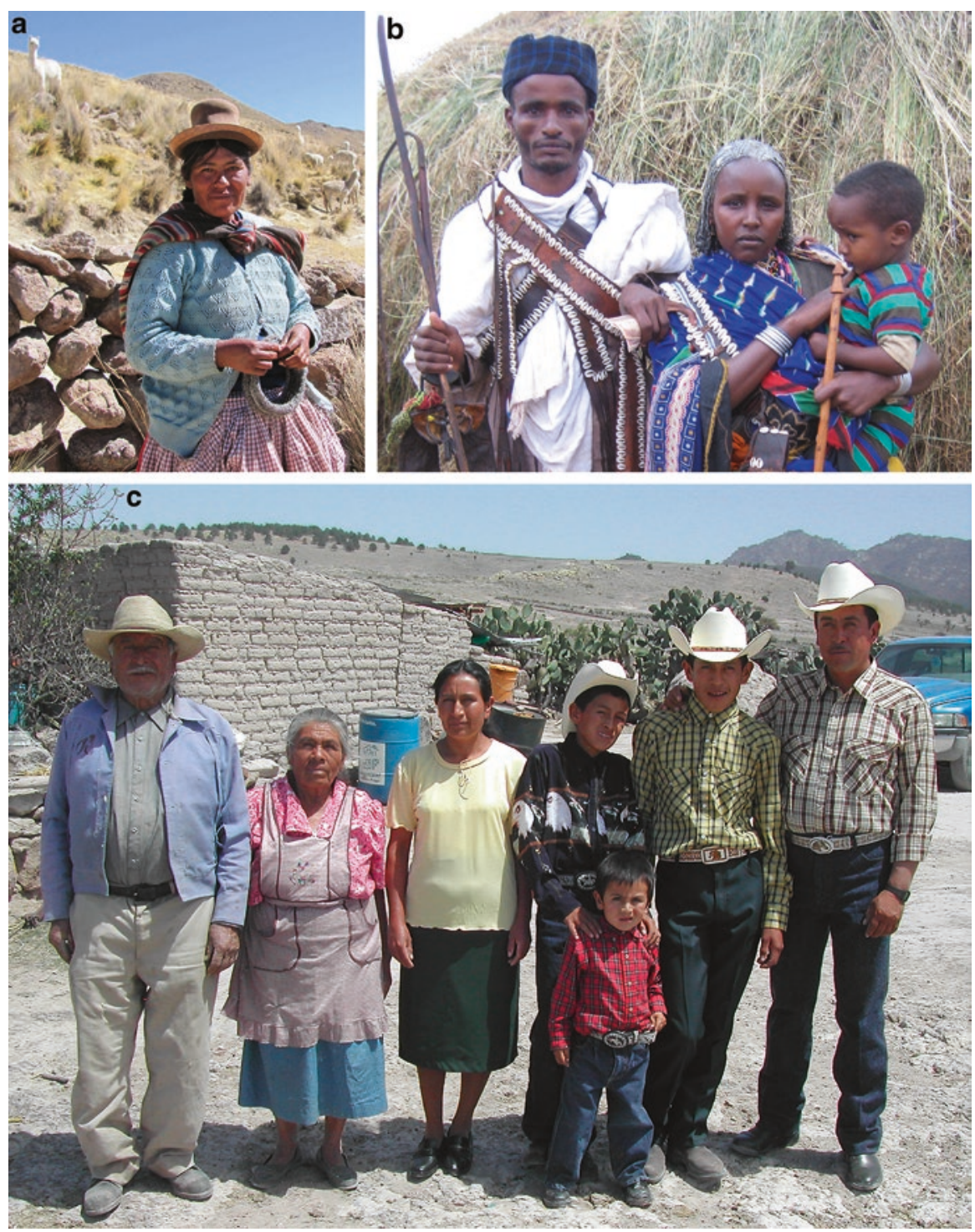

Fig. 17.2 (a-f). Pastoral and agro-pastoral people who reside in the rangeland study sites reviewed in this chapter: (a) Aymara woman on the Peruvian altiplano (photo credit: Cecilia Turin); (b) Borana family in southern Ethiopia (photo credit: Claudia Radel); (c) goat ranching family in northern Mexico (photo credit: José Tulio Arredondo); (d) Pashtun family in Afghanistan (photo credit: Michael Jacobs); (e) senior herd owners at a political meeting in Mongolia (photo credit: María Fernández-Giménez); (f) women drawing water from a well in the Sahel (photo credit: Matthew Turner) 

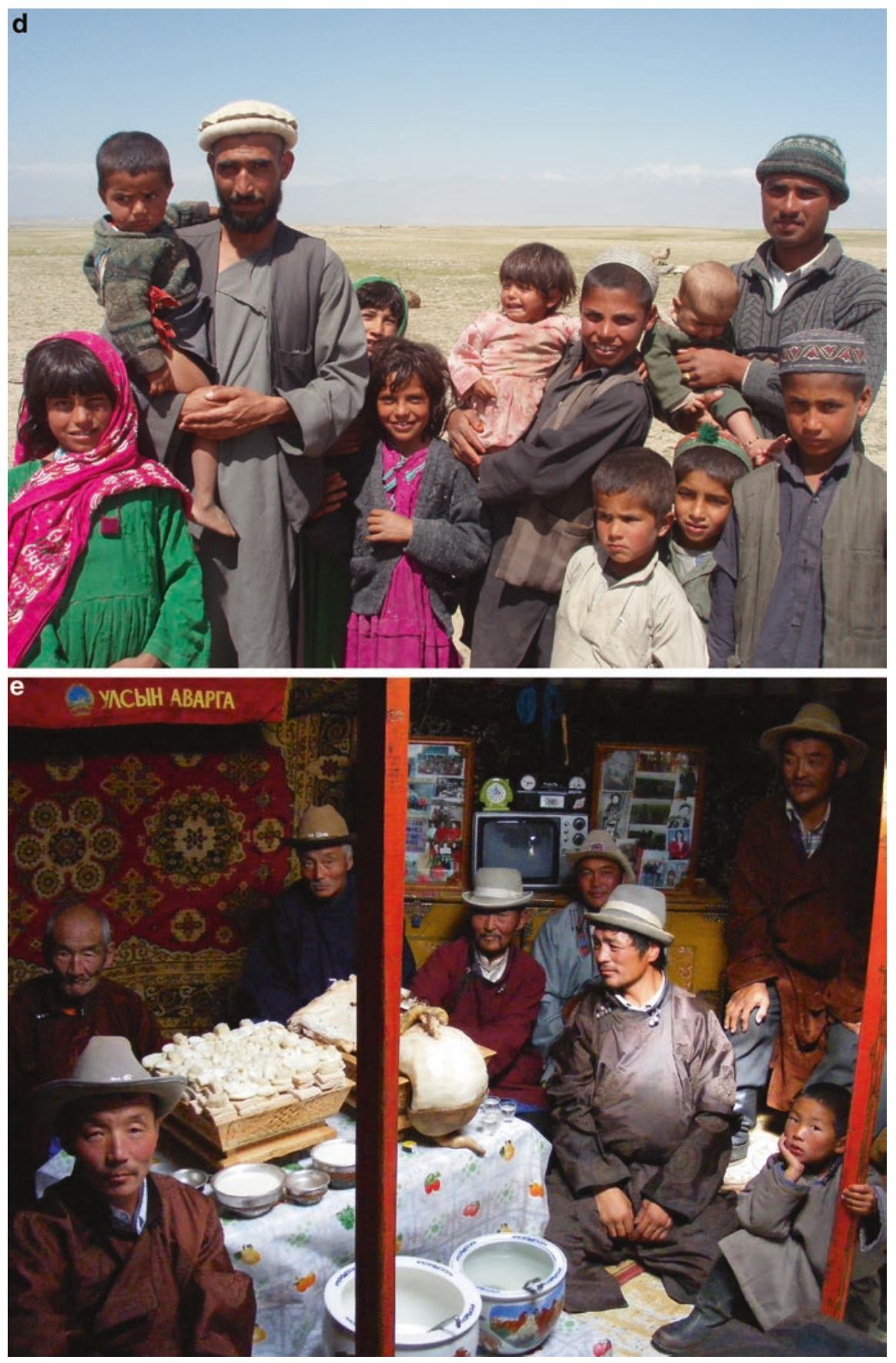

Fig. 17.2 (continued) 


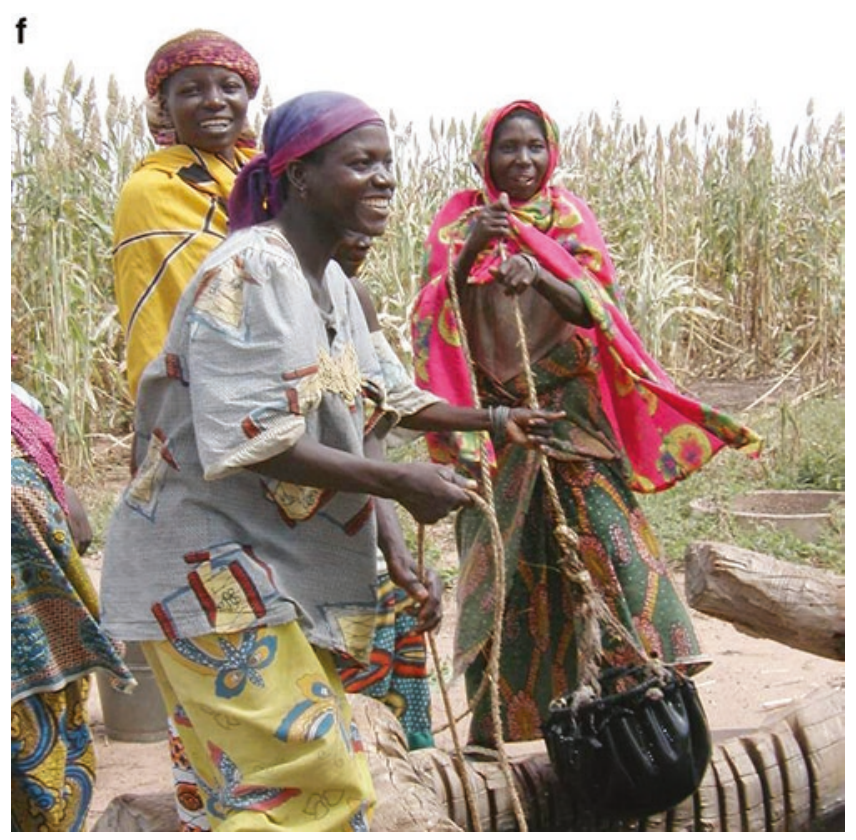

Fig. 17.2 (continued)

Rural population growth in the Altiplano is variable depending on location, but rates have been generally low in recent years (i.e., 0.4-0.7\%; Vera et al. 2006a, b). Seasonal emigration by Andean men seeking jobs in the cities or tropical lowlands is also common, especially in pastoral communities (Turin and Valdivia 2013). The human population of the northern Mexican rangelands can be broken out into two main groups: commercial ranchers (ganaderos) and a peasant class of pastoralists (ejidatarios). Numbers of people have risen and fallen - both with respect to birth rates and emigration - depending on the economy and the level of land degradation. Increases in the ganaderos community have occurred when the beef cattle industry expanded in the 1990s, but emigration of the ejidatarios has subsequently accelerated in response to land degradation (Schwartz and Notini 1994), drought (Feng et al. 2010), and US employment opportunities (Arredondo and Huber-Sannwald 2011; Ribeiro-Palacios 2012).

Patterns for Mongolia have been especially dynamic (Fernández-Giménez 2001; Leighton 2013). Following the transition from communism to a free-market economy in 1990, there was an influx of urban dwellers into the rangelands as people sought to claim livestock during privatization, when state property was distributed to local citizens. This trend has since reversed as more people now leave pastoral areas to seek urban employment. Fertility rates among Mongolian women have markedly declined over the past 20 years. ${ }^{5}$

\footnotetext{
${ }^{5}$ http://data.worldbank.org/indicator/SP.DYN.TFRT.IN?page $=4$
} 
When compared to sites in the upper tier, the Ethiopian site in the lower tier is characterized by more rapid net growth in residents that is related to a higher intrinsic rate of reproduction and relatively less opportunity for out-migration. Migration opportunities vary widely, however, across sub-Saharan Africa. In the Sahel, migration rates are high as people can move to cities and coastal nations of western Africa, northern Africa, and southern Europe (Tabutin and Schoumaker 2004). In the Sahel there has been a shift in livestock ownership to include agro-pastoralists as well as pastoralists (Turner et al. 2014). Ethiopian pastoralists, in contrast, have far fewer options (Coppock et al. 2011). Trends for Afghanistan are more difficult to discern as data are lacking. High losses of livestock due to conflict, insecurity, and droughtand few, if any, employment opportunities - however, suggest that human populations in the remote pastoral areas are also declining. These people appear to be settling near urban areas or joining refugee camps (UNHCR 2011).

In the upper tier, emigration from the rangelands is increasingly common, and this tends to occur more for men who seek employment as laborers in construction, mining, or farming. Women can thus be left behind to serve as caretakers of families and rangeland resources (Valdivia et al. 2013). Recently in Mexico women and children have joined men as migrants. A few decades ago it was job opportunities in the US that triggered emigration, but recent causes also include public insecurity related to organized crime (Martínez-Peña 2012). In Mongolia, recent rural to urban migration is influenced by the "push" factor of livestock loss in extreme weather disasters and the "pull" factor of people seeking better education and health care in urban areas (Leighton 2013).

\subsubsection{Livestock Populations}

Summary. Livestock (primarily including cattle, sheep, goats, equines, and camelids) provide the food and traditional economic basis for people living in the rangelands of developing countries; cultivation or wage employment opportunities are typically rare or nonexistent. The indigenous species and breeds are adapted to often harsh production conditions, and the flexibility of herd movement is very important for helping pastoralists cope with erratic rainfall patterns and disease outbreaks. Unlike the people on rangelands, population trends for livestock are more difficult to discern. Overall, livestock populations in some cases may exhibit "boom-and-bust" patterns where growth periods are followed by sudden die-offs due to combinations of weather, disease, or level of forage competition among livestock. The spatial scale and frequency of herd crashes vary markedly. The difficulty in mitigating large herd losses is due to low levels of economic development and public investment. Mitigating such losses matters, however, because recurrent dieoffs translate into large economic losses for pastoral societies. For less-developed regions where human survival is most closely linked to livestock survival, the ratio of animals to people provides an important indicator of both food and asset security. Where this ratio has been monitored, the evidence shows that it has markedly 
declined in recent decades. Politics, economics, and armed conflicts also influence range livestock populations, and examples of each are provided. Overall, there is no consistent long-term trend in livestock populations that is evident across our six case-study sites. Some populations follow a regular boom-and-bust pattern, while others show sustained increasing or declining trends in response to macro-level factors.

As shown in Table 17.1, range livestock produce multiple products for household consumption or sale at all case-study sites. These are largely indigenous breeds that are adapted to local climatic and foraging conditions (Krätli 2007). Examples of key species and breeds from the six case-study sites are pictured in Fig. 17.3a-f. Other food-producing animals found among rangeland dwellers include poultry, honeybees, and guinea pigs; these can be locally important to supplement household diets or incomes, but are generally insignificant in the rangelands when compared to the economy based on hoofed animals.

Because of low and highly variable precipitation, the world's rangelands have a comparative advantage in terms of extensive animal production, whereby unconfined animals seek and consume forage that is scattered across a landscape. Extensive animal production - while having its own risks and challenges - is far more reliable than rain-fed cereal cultivation in these environments-explaining why pastoralism prevails as the environment becomes more arid. The prevalence of agro-pastoralism, where producers combine crop cultivation with herding livestock, generally increases as the reliability and amount of precipitation increase (Jahnke 1982).

Commercial production of cattle, sheep, goats, camelids, and equines tends to be somewhat recent and increasing in many developing-country rangelands. The final market destination of these animals varies considerably among case-study sites, with some being sold domestically and others exported. Commercial livestock production is a departure for indigenous systems in which animals were traditionally produced for home consumption, often referred to as subsistence production (Jahnke 1982). Some regions such as the Sahel, however, have long-been centers of commercialized livestock trade (Kerven 1992).

The livestock population dynamics in most of our case-study sites are characterized by boom-and-bust patterns at different spatial and temporal scales. In the boom-and-bust, periods of steady growth in animal numbers are followed by sudden collapses when death rates soar due to starvation or disease that is triggered by weather events such as dry periods, multiyear droughts, extreme temperature fluxes, or heavy snowfall. Disease epidemics can also be implicated. ${ }^{6}$ In the case of conflict-ridden Afghanistan, when drought coincides with warfare herd losses can be catastrophic (FAO 2006). Both density-independent (e.g., weather) and density-

\footnotetext{
${ }^{6}$ In some cases previous development efforts to improve water access or reduce the prevalence of disease outbreaks were successful enough that such controls on animal numbers were relaxed. This resulted in more animals and a heightened demand for forage, with rangeland degradation as the ultimate outcome. Increased animal numbers, in theory, could be reduced by providing more marketing opportunities, but the traditional economic and cultural rationale in most pastoral societies to accumulate animals adds another layer of complexity that limits the rate of sustained offtake.
} 
a

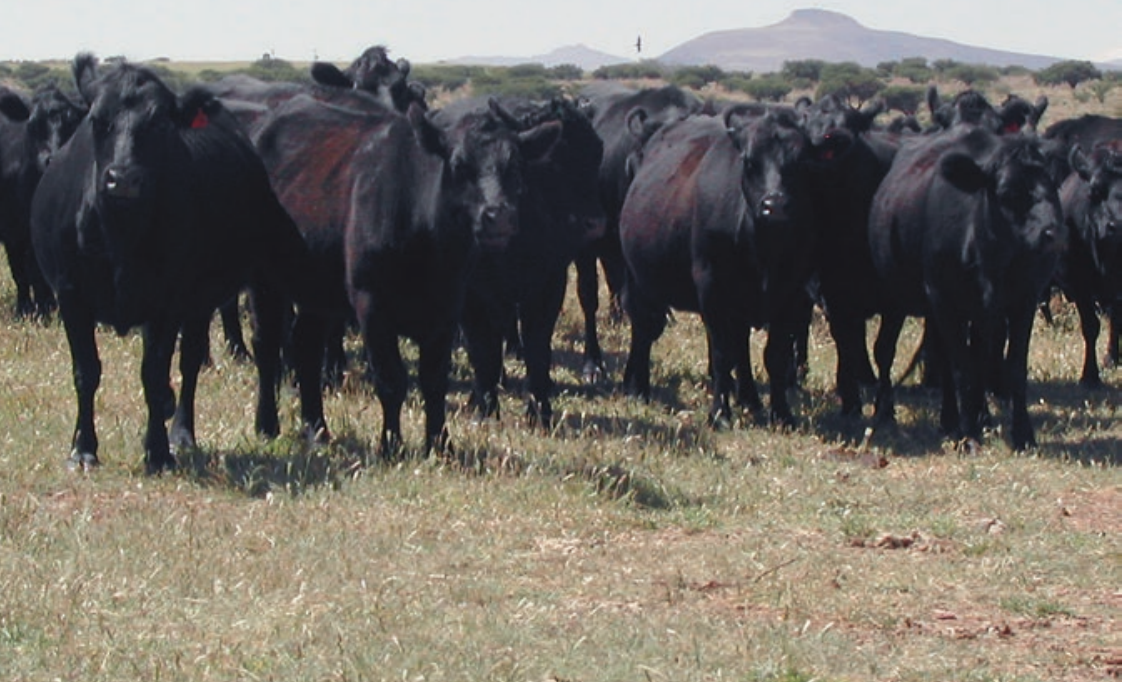

b

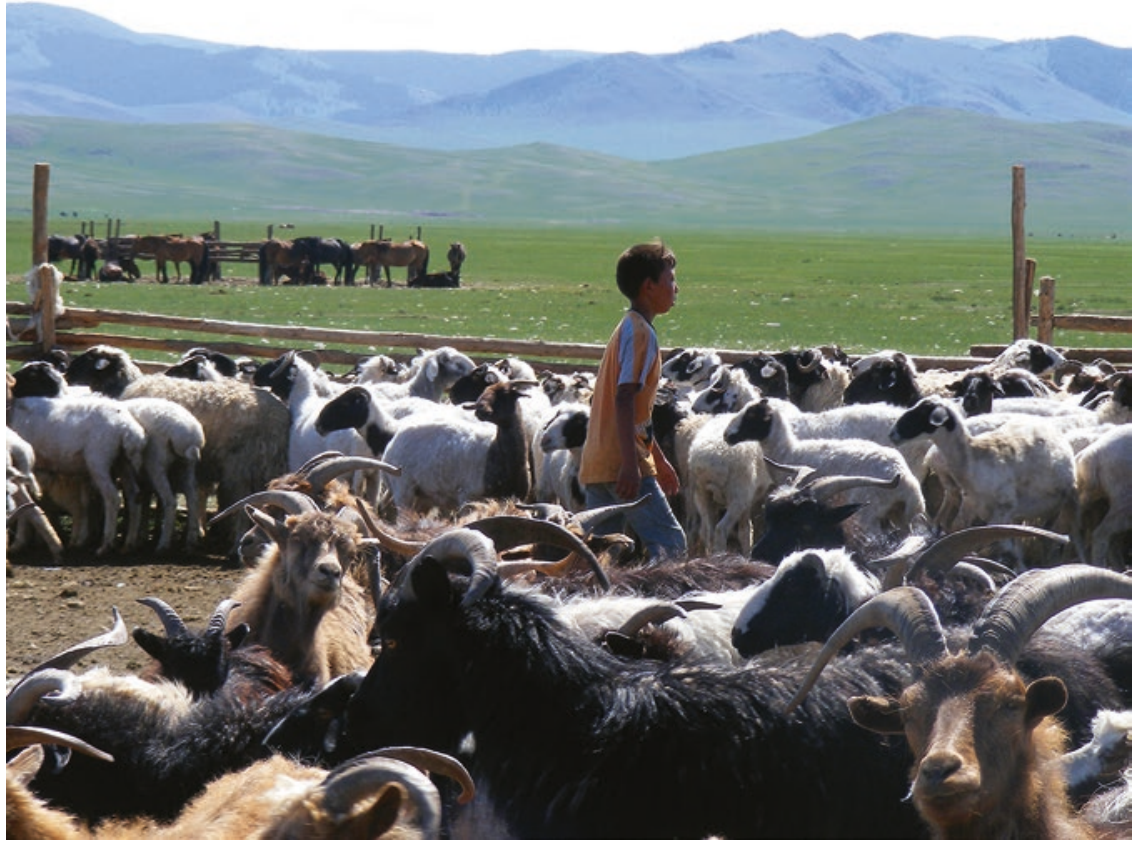

Fig. 17.3 (a-f). Livestock that are produced in the rangeland study sites reviewed in this chapter: (a) Improved Angus cattle in northern Mexico (photo credit: José Tulio Arredondo); (b) indigenous goats, sheep, and horses in Mongolia (photo credit: María Fernández-Giménez); 

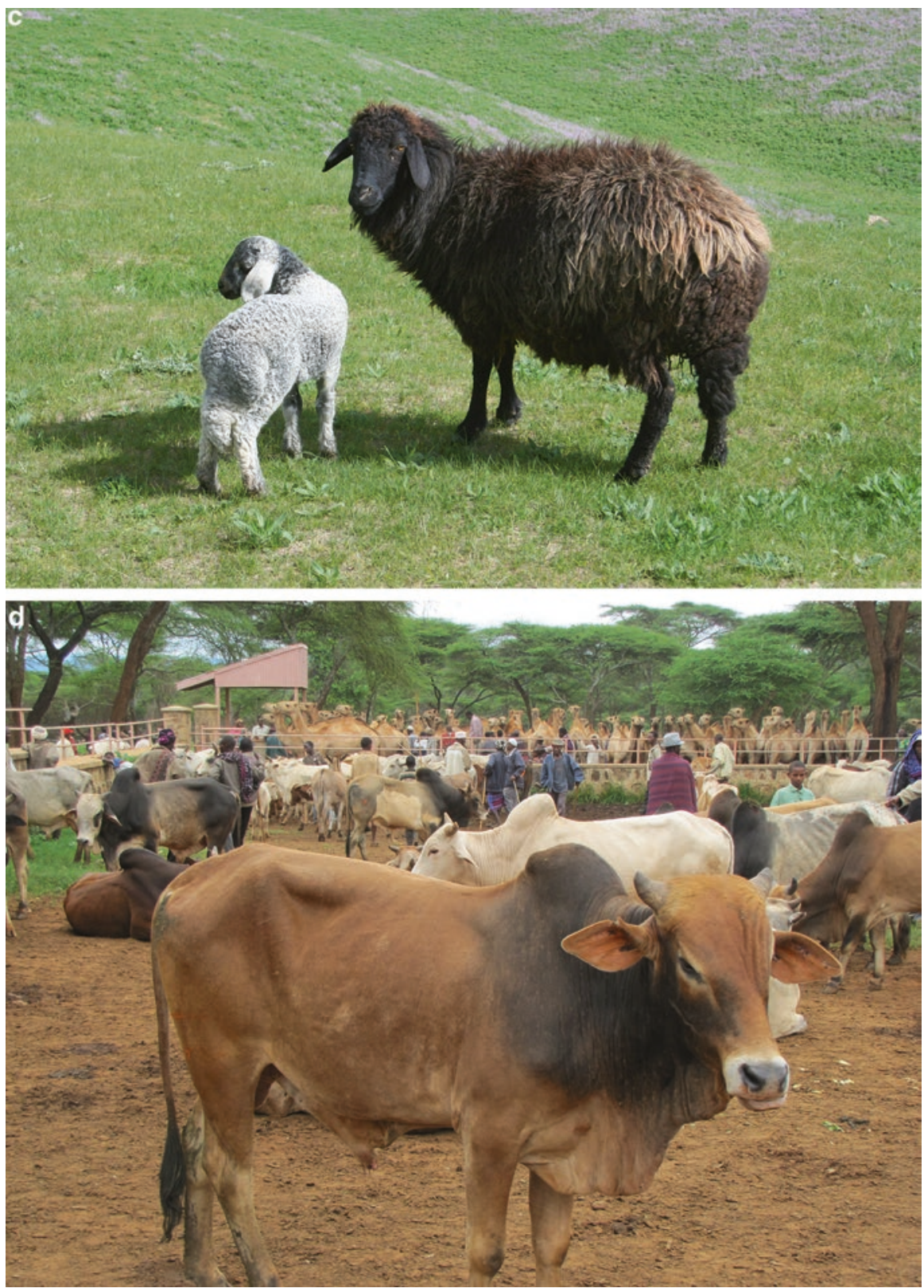

Fig. 17.3 (continued) (c) indigenous sheep in Afghanistan (photo credit: Michael Jacobs); (d) indigenous zebu cattle and dromedary camels in southern Ethiopia (photo credit: Brien E. Norton); (e) indigenous zebu cattle of the Sahel (photo credit: Matthew Turner); (f) llama on the Peruvian altiplano (photo credit: Cecilia Turin) 

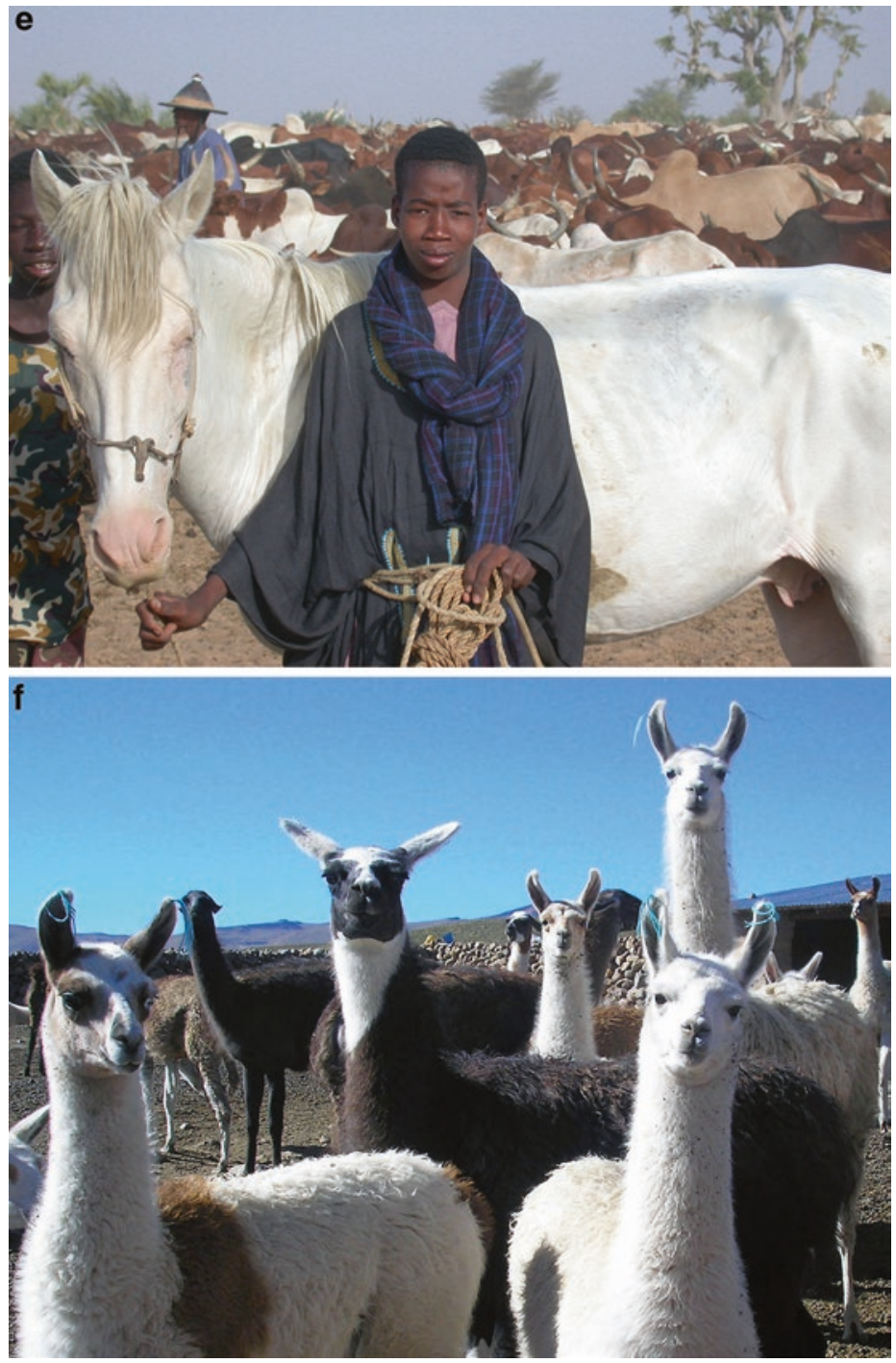

Fig. 17.3 (continued)

dependent (e.g., stocking rate or numbers of animals per unit area) factors can contribute to herd crashes. The number of years between consecutive herd crashes typically varies from 10 (Mexico; Garza-Merodio 2002) to 6 [southern Ethiopia (Desta and Coppock 2002) or Mongolia (Fernández-Giménez et al. 2012)]. Extreme cold events have contributed to a herd crash interval of less than 3 years in the Peruvian Altiplano (Moya and Torres 2008).

In the Sahel herd crashes occur at different spatial scales. The largest crashes have occurred following major regional droughts in 1972-1974 and 1983-1984 
(Toulmin 1987) as well as after a period of "cold rains" in 1991 (Toulmin 1987). ${ }^{7}$ Sahelian herd dynamics tend to be non-equilibrial (Ellis and Swift 1988). This means that livestock mortality events are influenced more by climatic factors rather than competition for forage among increasing animal numbers. It is more challenging for management to mitigate the effects of climatic factors compared to the effects of too many animals. In some systems interactions of high animal numbers with sudden drought or heavy snowfall can lead to sudden crashes in livestock populations.

Because the well-being of subsistence-oriented pastoralists is closely tied to livestock numbers, the ratio of livestock (e.g., tropical livestock units or TLUs ${ }^{8}$; Jahnke 1982) to people (e.g., African Adult Male Equivalents ${ }^{9}$ ) is an important measure of pastoral socioeconomic sustainability. ${ }^{10}$ And the higher this ratio is, the better. ${ }^{11}$ The ratio has been tracked in the two African sites where it has been shown to be in a steady decline over several decades, even going as low as 1:1 (Desta and Coppock 2004; Hiernaux and Turner 2002). This offers a stark contrast from historical highs that often exceeded a ratio of 10:1 (Gallais 1984). A sustained decline in the ratio means that per capita supplies of food (i.e., milk or meat) and capital assets (i.e., marketable animals on the hoof) are also declining; the inevitable result is thus increasing food insecurity and poverty unless livelihoods are diversified towards non-pastoral pursuits. The downward trend in the ratio for eastern Africa primarily occurs because the rate of human population increase exceeds that for livestock; this is partially due to the fact that far more animals perish during the "bust" phases than people do. Animals can be suddenly and severely limited by a scarcity of forage and water, and thus quickly starve to death. The people, in contrast, tend to suffer minimal losses to life as either they are rescued by human intervention (i.e., imported food aid) or they can migrate elsewhere and return when local environments improve. Patterns for the Sahel are somewhat different as growth rates for human populations in pastoral areas are low, but losses of animals occur because of shifts in livestock ownership from pastoralists to government officials, traders, and

\footnotetext{
${ }^{7}$ There were also major droughts in the Sahelian zone during the early twentieth century, but deaths of animals and people were lessened because the pastoralists were more mobile. The installation of permanent wells by governments began a process of settlement and a modification of pastoral risk management behavior (Sandford 1983).

${ }^{8} \mathrm{~A}$ tropical livestock unit (TLU) is $250 \mathrm{~kg}$ live weight [where one cow, sheep, goat, donkey, horse, or camel equals $0.8,0.1,0.08,0.6,1.0$, or 1.2 TLUs, respectively (Jahnke 1982)].

${ }^{9}$ An African adult male equivalent (AAME) is a measure of daily energy demand based on body size [where a male $=1.0$ AAME and is $\geq 16$ years old and weighs $55 \mathrm{~kg}$; an adult female $=0.8$ AAME; a male or female youth =0.8 AAME; and a child=0.6 AAME (FAO 1982)].

${ }^{10}$ Two livestock population statistics are of primary importance in pastoral systems, namely livestock holdings per capita and livestock stocking rate. The former is described in the text above. The latter is measured by the number of animals per unit area for a given period of time. Stocking rate becomes significant when one examines human or livestock support capacity per unit area. Shifts in stocking rate can influence herd or flock responses to droughts, with higher stocking rates increasing herd vulnerability in some cases.

${ }^{11}$ One analysis suggests that an increase of one person must be matched by a sixfold increase in TLUs for that extra livelihood to be sustainable (Thurow, personal communication).
} 
farmers. In West Africa most livestock are sold before they die of hunger except when a severe drought prevails (Turner, personal observation).

In any case, a period of herd rebuilding follows a crash, but this can be stressful because both food and assets remain in short supply (Desta and Coppock 2002). The ratio of TLUs to people has declined in most places and societies cope via diversification into agriculture, trade, or wage labor.

Long-term trends in livestock numbers across our case-study sites are difficult to discern largely because of inadequate data. It is still noteworthy, however, that the sites appear to vary with respect to overall trends. Some herd dynamics are complex and vary according to time frame as well as livestock species [i.e., sheep versus camelids in the Altiplano; Vera et al. 2006a, b], while other populations have either been steadily growing (i.e., cattle in northern Mexico; Perramond 2010) or markedly decreasing (i.e., sheep and goats in Afghanistan; FAO 2006).

Politics, economics, and armed conflict also influence range livestock populations. The best example of politics is Mongolia, where the collective era (19601990) was characterized by lower and stable numbers of livestock while the free-market era has witnessed several boom-and-bust cycles. Following privatization in 1992, animal numbers increased steadily until 1999-2003, when 30\% of the animal population perished in a series of severe winters. The population recovered and then crashed again during the winter of 2009-2010 (MNSO 2012). An example of economic effects is Mexico, where growth in the commercial production of beef cattle on the range dramatically increased in response to new US markets created by the North American Free Trade Agreement (NAFTA) in 1994. ${ }^{12}$ Armed conflict has influenced large-scale migrations of pastoral livestock in southwest Asia. During the Soviet-Afghan war in the 1970s and 1980s, many pastoral herds moved out of Afghanistan to Iran and Pakistan (Colville 1998; UNHCR 2011).

It is therefore difficult to generalize about range livestock populations. A boomand-bust pattern is perhaps the only feature that most of our case-study sites share, but the spatial scale and time interval vary markedly from place to place. The boomand-bust is indicative of poorly diversified rural economies (i.e., animals comprise the main investment option), the limited capacity of herders to manage risks and engage in asset diversification, and the inability of markets to absorb large numbers of animals quickly during crises. The Sahelian zone (and other locations) provides exceptions to this pattern, as herd losses do not occur with the same regularity there as observed in the other sites; the very large spatial scale of Sahelian pastoralism may be a factor in this distinction. And it is useful to note that large-scale die-offs are not simply dead animals, but rather represent large economic losses for rangeland dwellers in terms of capital assets and foregone income, the latter represented by a sudden drop in milk supply. Desta and Coppock (2002) speculated that several livestock herd crashes over 20 years in southern Ethiopia and northern Kenya may have resulted in a cumulative loss of nearly US $\$ 1$ billion, value that poverty-stricken pastoralists can ill afford to lose.

Livestock numbers may increase in response to commercial opportunities, but this appears more evident (as with northern Mexico) when commercial opportuni-

\footnotetext{
${ }^{12} \mathrm{http} / / / \mathrm{www} . u s t r . g o v /$ trade-agreements/free-trade-agreements/north-american-free-trade-agreementnafta
} 
ties grow in a sustainable fashion. Other examples include an increase in the population of cashmere goats in Mongolia in response to global demand for cashmere fiber (Fernández-Giménez, personal observation) and an increase in sheep holdings among agro-pastoralists in the Sahel in response to the large demand associated with Muslim holidays (Turner, personal observation). Pastoral livestock populations, however, are probably declining in Afghanistan (Thompson et al. 2005). Thus, overall, there is no evidence for consistent trends in livestock numbers across the six case-study locations.

\subsubsection{Socioeconomic Trends}

Summary. Overall, range livestock and their products are increasingly important for developing-country economies, although the relative contribution is low as other sectors expand. Rangeland dwellers are experiencing an expansion of livestock marketing options due to increasing domestic and export demand-and in some cases transportation infrastructure is also being improved. Ready access to public services such as potable water, electricity, health care, education, and banking services remains elusive for most rangeland dwellers, although access tends to be greater in the upper-tier sites compared to that of the lower-tier sites. Telecommunications have improved across the board, however, largely due to mobile phone networks. Traditional pastoralists have lower access to public services than do settled pastoralists or agro-pastoralists. Transition from communism to a free-market system in Mongolia has undermined the access of pastoralists to public services; other structural adjustments in the Sahel dismantled state-run veterinary and livestock services. Livelihoods are diversifying among agro-pastoralists, residents of settlements, and households whose members find employment outside of the rangelands. Wealth stratification among rangeland dwellers appears to be increasing overall as fewer people control more resources-a negative outcome of globalization. ${ }^{13}$ Food insecurity and extreme poverty occur in the lower-tier sites, but less so in the upper-tier. Social conflict takes a variety of forms, but it tends to be focused more on local control over natural resources in the Andean, Mongolian, and Sahelian situations. In contrast, the other case-study sites are subjected to a much wider array of conflicts - from resource-access squabbles among neighbors to struggles between drug cartels and long-term, major insurgencies.

Several of our case-study sites are in nations where rangelands are the predominant portion of the productive land area, with the main exceptions being Bolivia and Peru which have large portions of their lowlands in the moist tropics or subtropics. In Ethiopia, the Sahel, Afghanistan, Mongolia, and northern Mexico range livestock production is vitally important with respect to domestic supplies of live animals or animal products including hides, skins, and fiber (de Bruijn and van Djik 1995; Desta

\footnotetext{
${ }^{13}$ Globalization has been defined in many ways. Albrow and King (1990) define it as "all those processes by which the peoples of the world are incorporated into a single world society."
} 
et al. 2006; Niamir-Fuller 1999; Perramond 2010, Schloeder and Jacobs 2010; Turner et al. 2014; Zoljargal 2013). There is more variation with respect to the economic importance of range-related exports (Williams and Spycher 2003). Range livestock generate very significant proportions of national export revenue for Ethiopia (Desta et al. 2006), the Sahel (Zoundi and Hitimana 2008), and Afghanistan (Schloeder and Jacobs 2010). Such exports are relatively less important at the national scale, however, for Mongolia (World Bank 2013a), Mexico (Peel et al. 2011), or for nations that share the Altiplano (Valdivia 1991). On the Altiplano, fiber from alpaca and vicuña is locally important for artisan or textile industries, and there has been a surge in smallholder dairying in the agro-pastoral sector in response to increasing demand for milk among urban residents at high elevations (Valdivia 1991).

Markets for range livestock have grown overall during the past two decades as the global economy has expanded, stronger consumer countries have emerged, personal incomes have increased, rates of urbanization have accelerated, and trade barriers have been reduced (Meyers and Kent 2004). This bodes favorably for pastoralists over the long term, but producers living in remote areas - or subject to trade monopolies or intense competition-often remain isolated from market opportunities.

This isolation is often related to poor infrastructure, inefficient marketing networks, and lack of progressive policies. Road construction and rehabilitation are currently common across the rangelands of eastern Africa, spurred to a large extent by investors such as the People's Republic of China (Zafar 2007). Livestock marketing in general is a major priority in regional development initiatives concerning improvement in food security for the Greater Horn of Africa (Knips 2004) and the Sahel (CRCM 2013). Trends to improve rural infrastructure have also been observed for Mongolia (primarily stimulated by mining development), northern Mexico [primarily related to NAFTA and neoliberal policies including privatization of communal land (Perramond 2008)], and the high Andes (primarily related to international trade, especially in the Lake Titicaca region). Government decentralization has shifted more development funds and attention to the local level for some marginalized rangeland communities, with notable progress observed on the Bolivian Altiplano. Impact from decentralization has also occurred in southern Ethiopia (Coppock et al. 2011). Improvements in rural infrastructure, overall, are rare in the Sahel (Hesse et al. 2014) or Afghanistan (Mohmand 2012).

Public service provision for rangeland dwellers remains as a major obstacle for progress. Poor nations typically do not have the resources to make development investments in remote locations. There are two distinct subpopulations emerging in the rangelands of the developing world: one consists of traditional, mobile pastoralists still largely dependent on livestock, while the other consists of sedentary or semisedentary residents of growing rangeland towns and cities that have more diversified livelihoods. The latter group includes agro-pastoralists, former pastoralists, sedentary pastoralists, and immigrants from other sectors. Sedentary pastoralists may have households where some members are fully settled and have wage employment, with other members traveling to distant locations as they herd the family's livestock. 
In such settlements access to potable water, electricity, health care, schools, and banking services can still be lacking. Public awareness of the need for services is increasing, and appreciation of education is rising among many rangeland dwellers (Coppock et al. 2011). Service provision to mobile pastoralists is much worse than that for town dwellers across all of our case-study locations. Most traditional rangeland populations have never had public services, so any progress is an improvement. An interesting exception, however, is Mongolia where during the communist era nomads received heavily subsidized services including education, health care, and veterinary care (Fernández-Giménez 1999). This resulted in high rates of literacy as well as successful vaccination campaigns. In the free-market era these services have been lost or greatly diminished. The one bright spot in service provision on the rangelands concerns improved telecommunications; each of our case-study sites have witnessed expansion of mobile phone use in the past 5 years.

Pastoral households across our case-study sites are commonly near or below the poverty line. Compared to the past, trends indicate that traditionally oriented pastoralists are generally getting poorer and thus have a higher risk exposure to perturbations caused by weather, economy, or conflict. Although illiteracy rates remain high in most cases, more pastoral children are reportedly attending school and, where local circumstances allow, pastoral households increasingly attempt to diversify incomes and assets by mixing pastoral with non-pastoral activities (Coppock et al. 2011). Food insecurity remains common for pastoralists in the lower tier; Afghan and African pastoralists often receive food aid (Coppock et al. 2014; Schloeder, unpublished data). One extreme case, for example, is the $40 \%$ of Afghan Kuchi pastoralists who remain in refugee camps (Colville 1998; USAID 2007). Food aid is pervasive in the Sahel ${ }^{14}$ as well as in the Greater Horn of Africa. ${ }^{15}$

Livelihoods for pastoralists in the upper tier are relatively better in that food (both in terms of production and access) is less of a problem. A common concern for rangeland dwellers in Mongolia, the Altiplano, and northern Mexico is the cost and effort needed to gain access to secondary or tertiary education (Fernández-Giménez, personal observation; Kristjanson et al. 2007; Martínez-Peña 2012). ${ }^{16}$

In Mongolia, the proportion of rural households living in poverty greatly increased in the early years of the free-market transition (Griffin 2003; Nixson and Walters 2006). There has since been a gradual recovery, but this has been disrupted by large herd crashes caused by severe winter weather. Considerable development attention has recently been given to strengthening community-based organizations to fill resource governance gaps created by de-collectivization (Fernández-Giménez et al. 2015; Leisher et al. 2012; Upton 2012).

In Afghanistan, socioeconomic progress was halted by war with the Soviet Union, and poverty rates remain high following the $\mathrm{NATO}^{17}$ intervention that began

\footnotetext{
${ }^{14} \mathrm{http} / / /$ ec.europa.eu/echo/aid/sub_saharian/sahel_en.htm

${ }^{15} \mathrm{https}$ ://na.unep.net/geas/getUNEPPageWithArticleIDScript.php?article_id=72

${ }^{16}$ Residents of ejido villages in northern Mexico now have access to low-cost distance education programs.
}

${ }^{17}$ North Atlantic Treaty Organization: http://www.nato.int/cps/en/natolive/topics_8189.htm 
in 2001. Weak government institutions, corrupt administrations, lack of physical security, and a ruined rural economy have stymied development progress in general for Afghanistan (Mohmand 2012). In addition, there has been a lack of development aid targeted specifically for pastoralists in Afghanistan. For 2008, for example, pastoralists reportedly received only US $\$ 0.20$ per person compared to US\$60.00 per person for non-pastoralists (Mohmand 2012).

For Mexico, increasing affluence of consumers has translated into an accelerated demand for grain-fed beef. In response, mega-ranches with intensive feedlot production have emerged in northern Mexico, while traditional smallholders on communal lands are being squeezed out of the market (Henriquez and Patel 2004). Government subsidies and high remittances are common inputs for Mexican producers - this makes them distinct when compared to rangeland residents in our other case-study sites. The NAFTA has opened cross-border markets with the US as well (NAFTA 2000).

All of our case-study sites exhibit trends where stratification among rangeland producers is widening the gap between the haves and have-nots. This is often triggered by elites ${ }^{18}$ who have the connections and skills to take advantage of commercial livestock opportunities, build larger herds, and gain de facto control over more natural resources. ${ }^{19}$ Stratification can leave the majority of the population more marginalized (Coppock et al. 2014). In other cases such as the Altiplano (Kristjanson et al. 2007), however, increased vulnerability is observed primarily among the elderly.

Finally, ethnically based or resource access-related social conflicts at large spatial and temporal scales are pervasive challenges for rangeland dwellers in Afghanistan and the African sites. In Mongolia, social conflict over resources is more localized and related to pasture and water access (Fernández-Giménez et al. 2008), although conflicts between herders and mining interests are increasing (Fernández-Giménez, personal observation). Similarly, in the Altiplano, conflicts have occurred around water resources and between herders and mining interests (Turin, unpublished data). In northern Mexico, unequal access to agricultural land and contested grazing rights for non-ejidatarios have caused long-lasting internal conflicts in the communal areas (ejidos). More recently, extensive drug trafficking and conflicts between government and drug lords have disrupted ranching as well as other forms of commerce (Martínez-Peña 2012). In the Sahel, insurgencies tied to radical Islamic ideology have emerged (Larémont 2011). Such developments in Mali, however, have not affected pastoral mobility patterns. Banditry associated with general insecurity is viewed as a more chronic problem overall (Turner, personal observation).

\footnotetext{
${ }^{18}$ Defined as a group of people who exercise the major share of authority or influence within a larger group, often associated with a greater degree of wealth.

${ }^{19}$ This process is not unique to developing country rangelands; rather, it is the rule, not the exception. There are similar examples of elite takeover during the rangeland settlement era in the US and Australia, for example. It is desirable to learn from the past and mitigate hardships in developing nations as change accelerates (Thurow, personal communication).
} 


\subsubsection{Trends in Resource Use and Ecological Condition of Rangelands}

Summary. This section describes the environments of the six case-study sites. Although climate, landscapes, vegetation types, and land use vary greatly among the case-study sites, all share common patterns of soil erosion, vegetation change, or rangeland fragmentation due to intense and chronic exploitation of natural resources by people and livestock, regardless of whether a site occurs in the upper or lower tier. Both subsistence and commercial livestock production systems appear to push resource use to the limits. Climate change assessments typically portray a warmer and drier future for most of the sites except the Sahel, which may become wetter. Forage supplies are often barely sufficient to carry livestock through the dry seasons of "normal" rainfall years, let alone droughts, contributing to the boomand-bust herd dynamic previously described for some locations. The most damaging and irreversible result of extractive land use is the accelerated erosion of topsoil. Although overgrazing is often mentioned as the main cause of accelerated soil erosion, dryland farming, overharvest of wood for fuel and building materials, and poorly designed roads can sometimes be more important in this regard.

The environments in our case-study sites are described in Table 17.1. They markedly vary in terms of climate and plant communities. Images of representative landscapes are shown in Fig. 17.4a-f. Overall, despite high variation in human and livestock features of our case-study sites, trends in resource use and ecological condition of rangelands are similar.

Afghanistan is a very mountainous country located in the arid-subtropics of Asia. In the mountains the winters are cold and snowy. Nationwide, the summers are hot and dry. ${ }^{20}$ Multiyear droughts are common, as are major dust storms. The range livestock are dominated by five breeds of sheep and two breeds of goats and their crosses. Breeds vary in their tolerance of poor forage quality and resistance to disease, and hence their dominance varies by region. The seasonal grazing patterns followed by most Afghan herders include pasturing of livestock: (1) near camps and residences at low elevations during winter where snowfall is moderate ${ }^{21} ;(2)$ at sites close to the winter range that green-up early during spring; (3) at progressively higher elevations during summer (up to $2500 \mathrm{~m}$ or more) as animals follow an altitudinal gradient of green-up; and (4) back at the same type of sites in the fall that were previously used in the spring.

Land degradation in the form of soil erosion is commonly attributed to overgrazing by goats and sheep, although hard causal evidence is often lacking. Major contributors to excessive soil erosion are more likely to include dryland cultivation (in general) and the overharvest of woody and nonwoody materials for fuel, food, medicinal plants, and building supplies (Jacobs et al. 2015). Dust storms also con-

\footnotetext{
${ }^{20} \mathrm{http} / / / \mathrm{www} . n \mathrm{dc}$. noaa.gov/oa/climate/afghan/afghan-narrative.html

${ }^{21}$ Hand feeding of natural forage may occur in high snowfall years.
} 


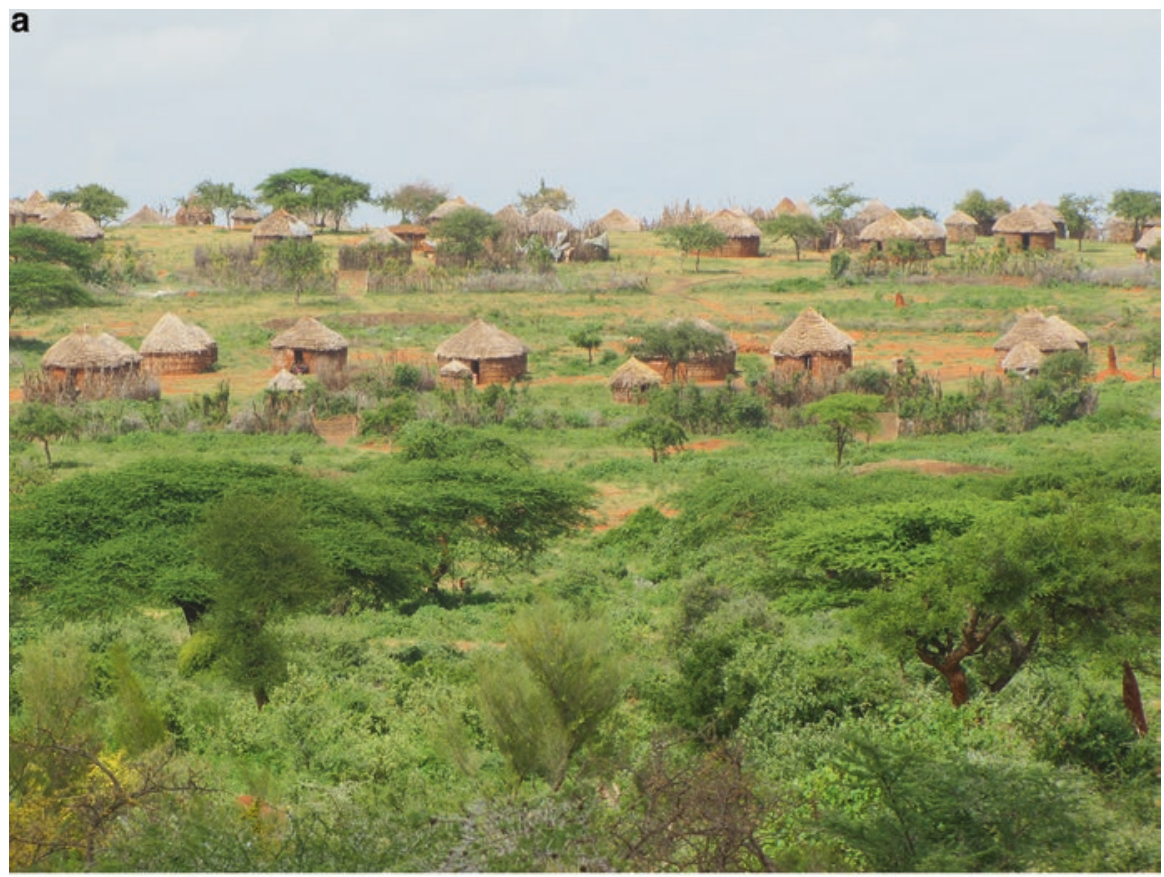

b

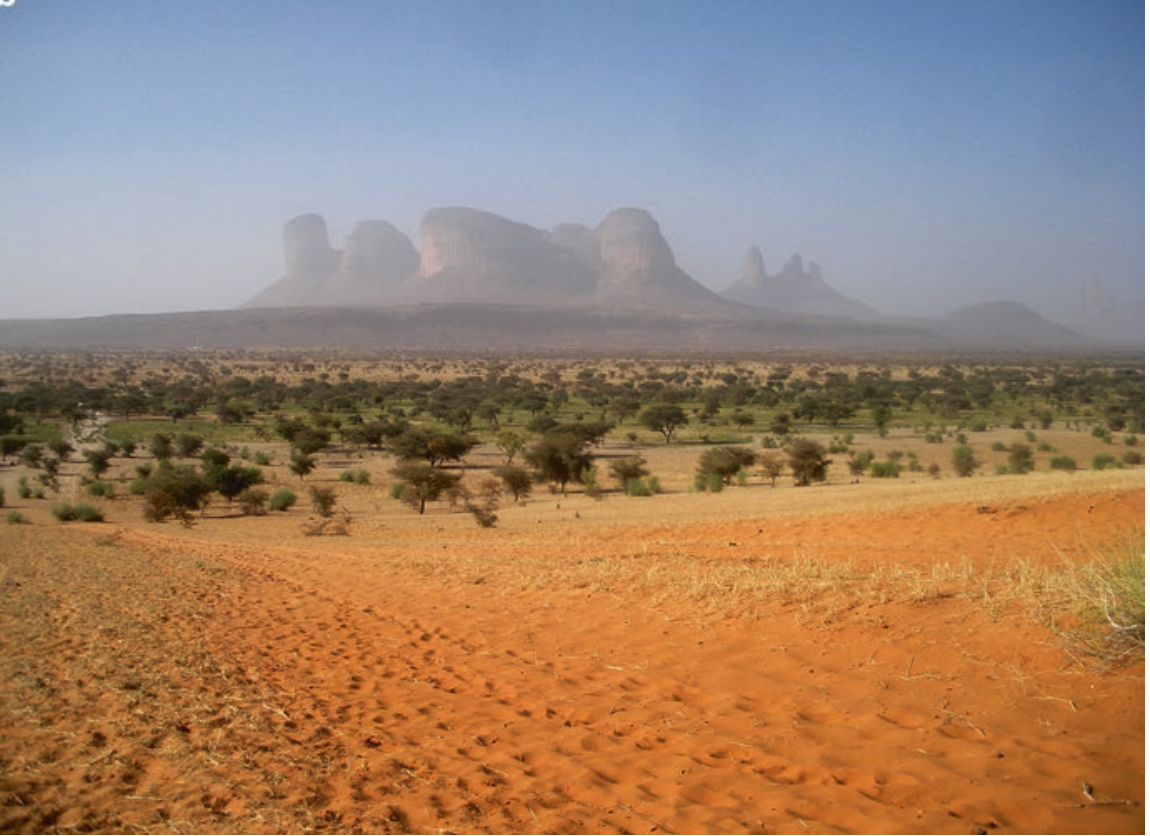

Fig. 17.4 (a-f). Landscapes in the rangeland study sites reviewed in this chapter: (a) Borana encampment in southern Ethiopia (photo credit: Brien E. Norton); (b) Gourma landscape in the Sahel (photo credit: Matthew Turner); (c) grassland in the Peruvian altiplano (photo credit: Cecilia Turin); 

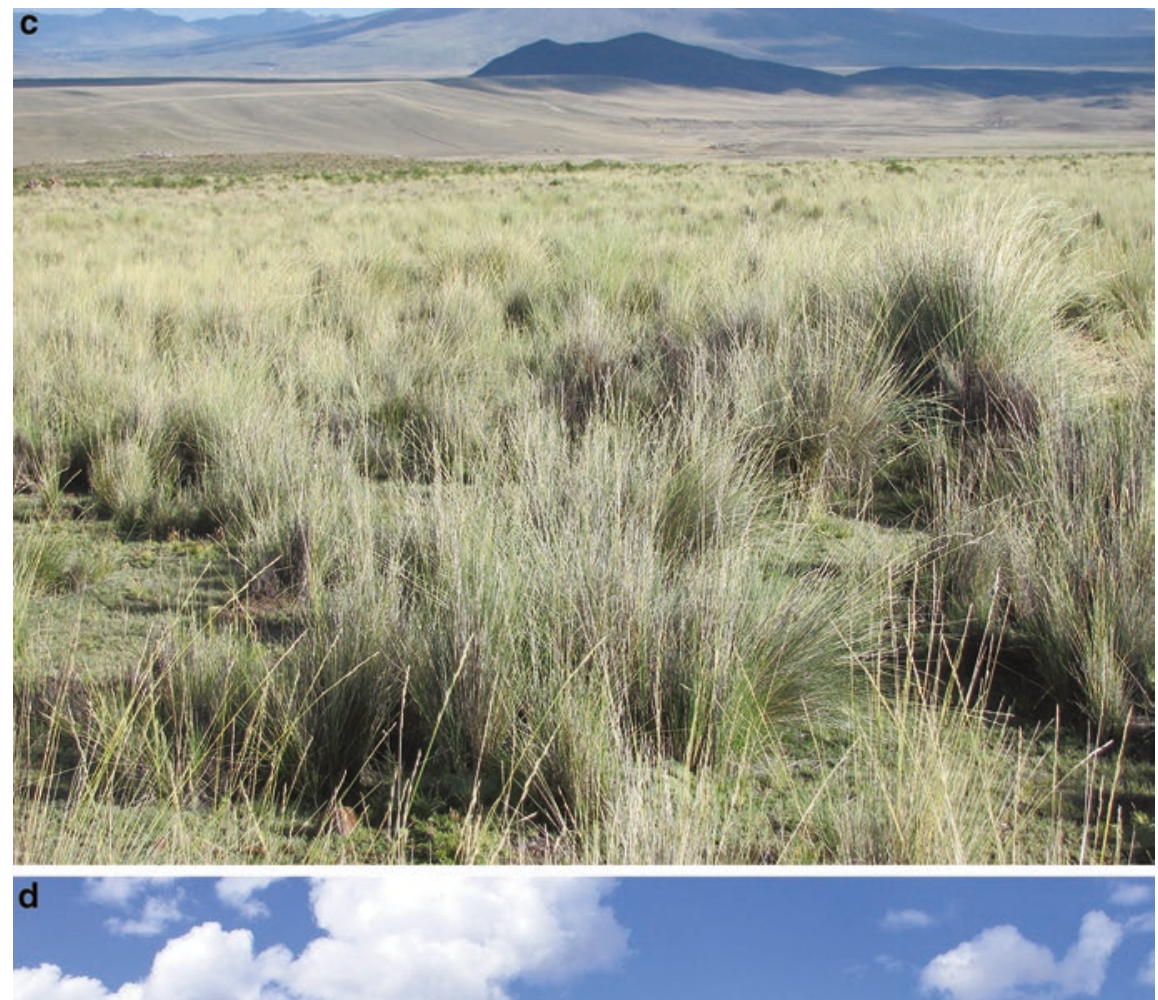

d $x+4$

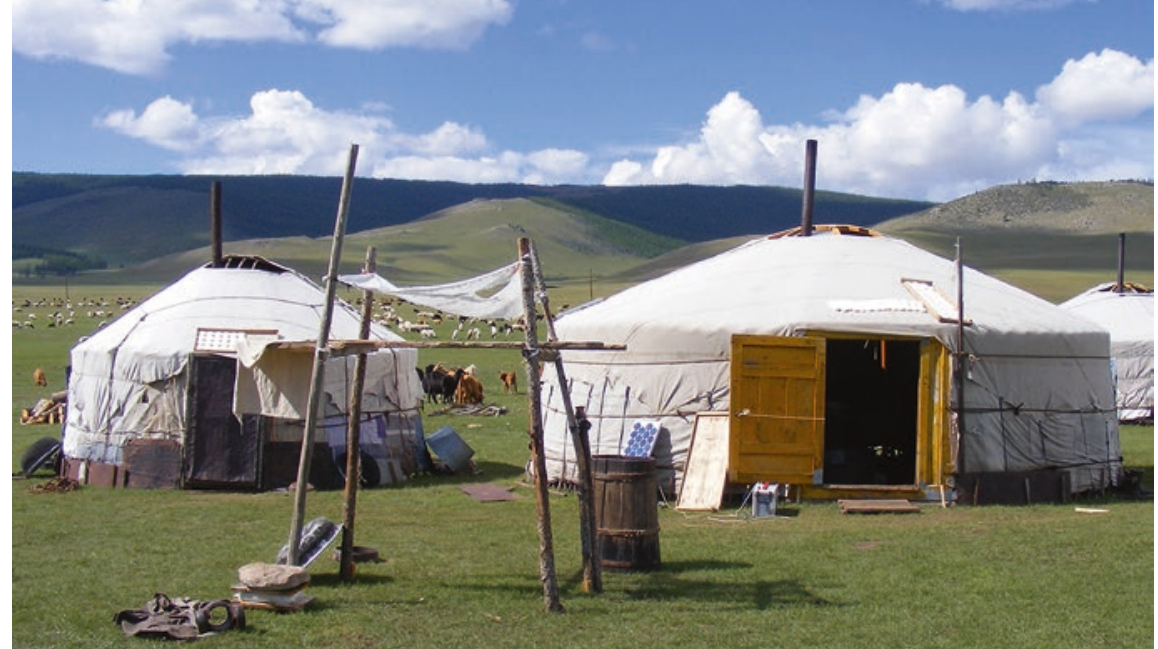

Fig. 17.4 (continued) (d) herding camp in Mongolia (photo credit: María Fernández-Giménez); (e) irrigated wheat and hillside range in Afghanistan (photo credit: Michael Jacobs); (f) tobosagrass rangeland in northern Mexico (photo credit: José Tulio Arredondo) 


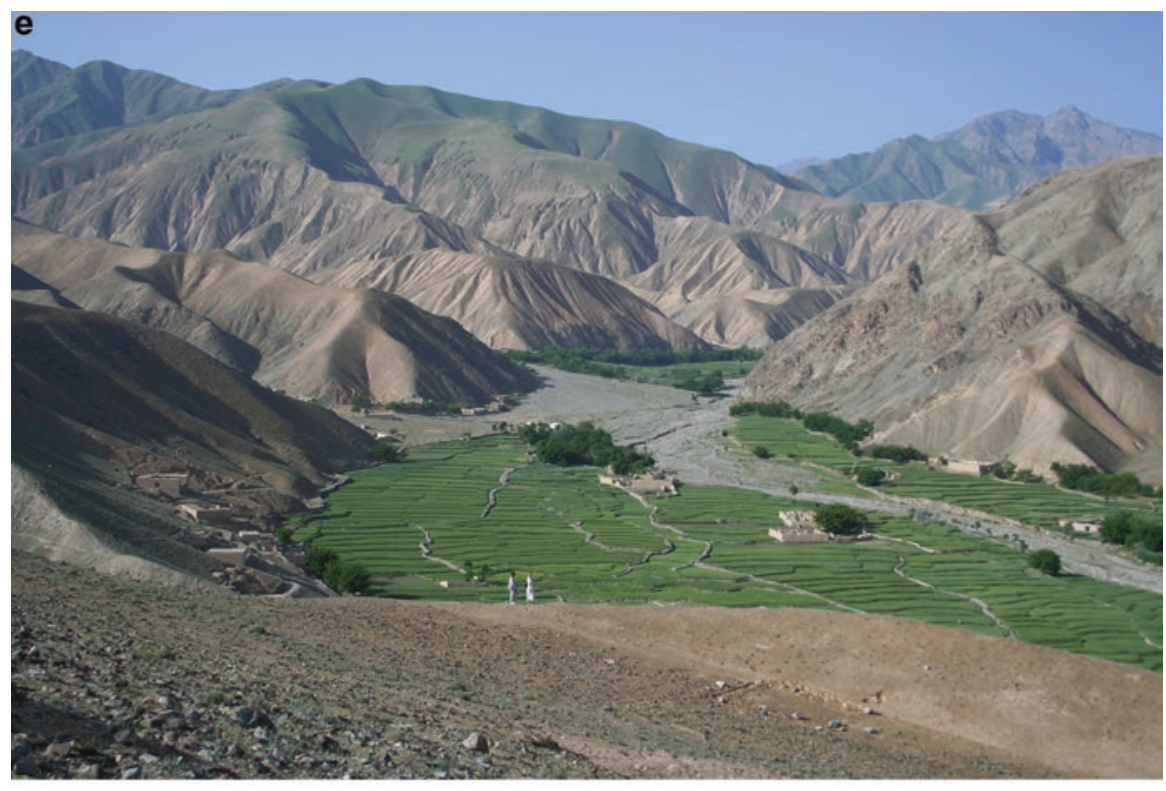

f

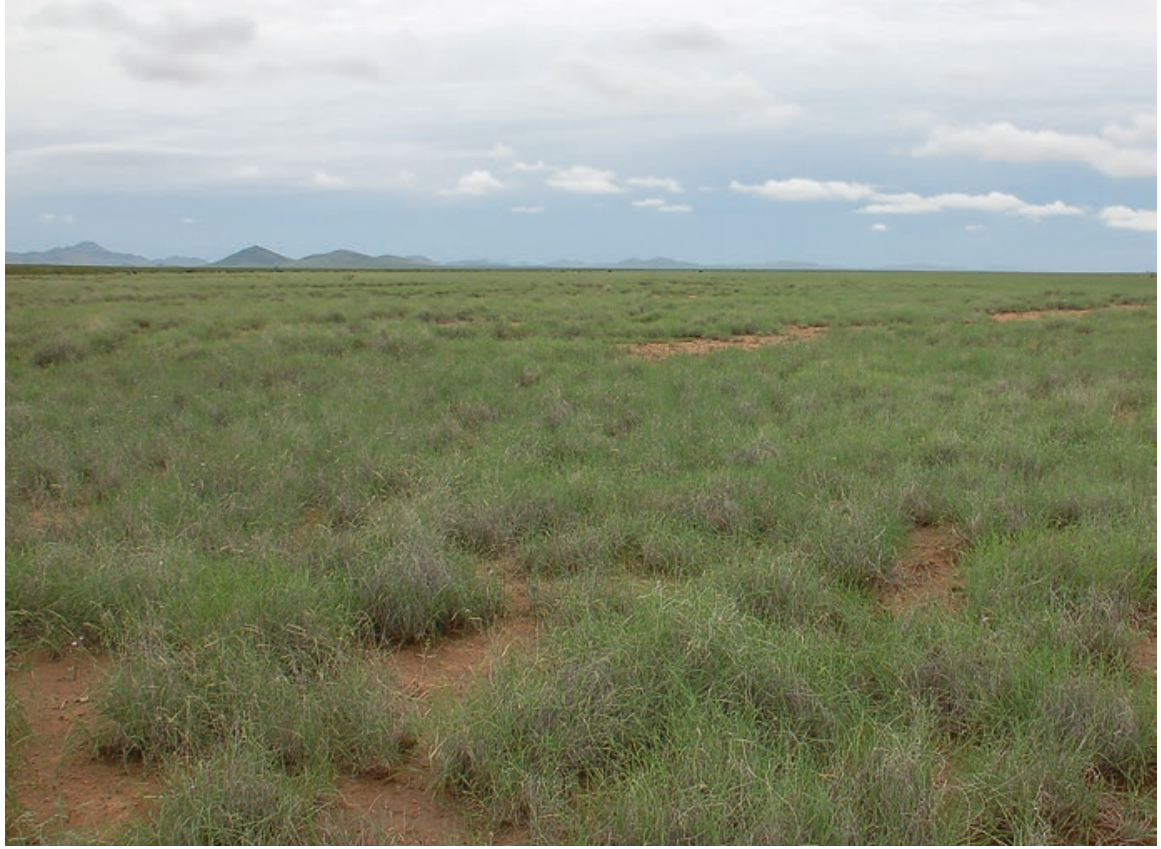

Fig. 17.4 (continued) 
tribute to wind erosion. Climate change studies indicate warming and drying trends, both in the recent past and future forecasts (Savage et al. 2009). Currently, unsustainable dryland cultivation is the greatest threat to livestock survival during winter, spring, and fall when the high-elevation summer pastures are unavailable. Sustainable dryland cultivation is the greatest threat in terms of the fragmentation of pastoral migration routes and staging areas. ${ }^{22}$ Both situations will only get worse if climate change scenarios are verified, as more cultivated areas are abandoned in the most fragile landscapes and drought becomes the norm rather than just a temporary or cyclic event.

The Ethiopian situation illustrates too many people and livestock (i.e., cattle, sheep, goats, and camels) exploiting a diminishing natural resource base. This trajectory was predicted over 20 years ago (Coppock 1994). Symptoms are ecological and socioeconomic (Coppock et al. 2014). The former include bush encroachment and gullying on certain soil types. The latter include land-use fragmentation due to de facto privatization of grassland parcels annexed from communal resources, loss of dry-season grazing to maize cultivation, and occupation of former drought grazing reserves by people who have arrived from overpopulated places elsewhere. Bush encroachment has been exacerbated by decades of overgrazing and (past) official bans on the use of prescribed fire that have shifted the competitive balance from perennial grasses to woody plants (Coppock 1994). This loss of grasses means a decline in fine fuels that are needed to carry fires that might otherwise control the recruitment of woody seedlings. Maize cultivation by pastoralists is a food insecurity response to a declining ratio of livestock to people and thus is symptomatic of the trend of increasing poverty (Desta and Coppock 2004). Chronic food insecurity has led to dependence on food aid, the provision of which effectively delays resolving the root causes of hunger (Coppock et al. 2014).

The Sahel differs from southern Ethiopia in many respects, but shares some of the same broad outcomes. The Sahelian belt occurs at a continental scale, with far more variation in terms of climate, land use, and rangeland ecology (Table 17.1). Sahelian production systems vary from pure pastoralism to highly integrated agropastoralism where crop residues provide livestock fodder, and livestock manure enhances crop yields (Heasley and Delehanty 1996; Turner et al. 2014). In the Sahel the overall challenge for pastoralists is how to exploit the highly variable occurrence of fodder over space and time most efficiently. Fragmentation of landscapes and natural resource endowments has occurred due to population growth, spread of cultivation, and national policies that attempt to reassert tougher border controls, although efforts have occurred to accommodate pastoral mobility across national borders (Zoundi and Hitimana 2008). In some instances, however, cultivation has remained stable or retreated due to variation in local population growth and climate patterns (Tappan et al. 2004). Pressure on grazing resources from cultivation is particularly a problem in the southern Sahel where seasonal, long-distance livestock movements to the north during the rainy season (e.g., transhumance) have been

\footnotetext{
${ }^{22}$ Staging areas are places where livestock rest for extended periods before continuing on to lower or higher elevations.
} 
historically important. Interestingly, a "re-greening" of the Sahel has been observed over the past 30 years from satellite images (Olsson et al. 2005) and verified by field work (Dardel et al. 2014) where rainfall and net primary productivity have increased, and this mitigates some otherwise negative trends (Gardelle et al. 2010; Hiernaux et al. 2009, Leduc et al. 2001). Vegetation change in the Sahel appears to be more influenced by precipitation than livestock effects and thus is an example of nonequilibrium dynamics (Ellis and Swift 1988) ${ }^{23,24}$.

Mongolian rangelands today are increasingly at risk from heavy livestock grazing (Liu et al. 2013) as well as soil degradation associated with road networks (Keshkamat et al. 2013) and pollution of soil and water from the expansion of mining (Thorslund et al. 2012). There is debate, however, about the causes of declining range conditions in Mongolia (Addison et al. 2012). Livestock pressure may be interacting over space and time with dynamic climate belts to alter vegetation cover, with the mix of drivers likely changing in different ecological zones (Cheng et al. 2011; Wang et al. 2013; Wesche et al. 2010). As in the Sahel, several studies have shown that livestock grazing has less impact on vegetation than precipitation in the desert-steppe region of Mongolia (Fernández-Giménez and Allen-Diaz 1999; Wesche et al. 2010). Livestock play a more significant role in vegetation dynamics of the wetter mountain steppe and steppe zones, where livestock populations have increased most dramatically in the past 20 years (Fernández-Giménez and Allen-Diaz 1999).

The Altiplano is also comprised of diverse landscapes. Indigenous pastoral and agro-pastoral production systems were very efficient in growing crops or rearing livestock at different elevations in the Andes, but this was dismembered during the Spanish Conquest (Flores-Ochoa 1976). Today, lower elevations on the Altiplano (3700-4000 m) are dominated by agro-pastoralism that includes sheep and cattle, while higher elevations $(>4000 \mathrm{~m}$ ) are dominated by pastoralists raising camelids (CIRNMA 1997). Forage resources are either communal or privatized. Population growth is reducing the per capita base of natural resources and there is pressure to reduce long fallow periods for dryland crops. Climate research has documented that

\footnotetext{
${ }^{23}$ Work by Ellis and Swift (1988) concerned the nomadic pastoral system of South Turkana, Kenya. The system components include a diverse assemblage of livestock species that forage in a drought-pulsed, arid region subtended by sandy and volcanic soils. Plants are dominated by annual grasses, dwarf shrubs, and Acacia shrubs and trees. Ellis and Swift proposed that South Turkana was a nonequilibrium system, meaning that livestock stocking rates would not get high enough to effect significant change in the plant community via their foraging and trampling activities. Frequent droughts in South Turkana decimate livestock numbers to keep their influences low, and the annual grasses and sandy soils, in any case, are resistant in the face of livestock pressure. The productivity and abundance of annual grasses, in particular, are thus primarily affected by the pattern and amount of annual rainfall, not livestock. This is in contrast to an equilibrium system where livestock can exert directional pressure over time on the perennial grass community and the upland soils (i.e., soils having a mix of sand, silt, and clay). This pressure can lead to soil erosion and significant changes in plant community composition. An example of an equilibrium system is found less than 500 miles from South Turkana in a higher elevation, semiarid region called the Borana Plateau (Desta and Coppock 2002).

${ }^{24}$ There are examples in the Sahel, however, where people have had a decisive role in overriding climate effects and impacting the environment. Intense grazing and cultivation in some parts of Niger have proven incompatible with the arid climate, resulting in large areas of formerly productive Andropogon grasslands now being devoid of topsoil (Thurow, personal communication).
} 
the Altiplano is becoming warmer and drier (Seth et al. 2010). This has implications for reducing forage quality (Zorogastúa-Cruz et al. 2012) and drying of evergreen peat bogs (bofedales) that are fed by glacial melt and provide key grazing for camelids (i.e., alpaca and, to a lesser extent, llama). There are also instances where increased land pressure occurs when too many families reside in the same area or when remittances are heavily invested in livestock (Turin and Valdivia 2011).

Emigration of men or youths seeking urban jobs or secondary schooling has undercut the labor supply for herding and managing natural subirrigation systems. In some instances introduced forages (e.g., alfalfa) have been successfully established in agro-pastoral zones, reducing pressure on native range and allowing expansion of smallholder dairy operations (Turin and Valdivia 2013). For Bolivia, Healy (2001) documents how tractor introduction -in support of expanding quinoa cultivation - has displaced llama production.

The rangelands of northern Mexico are comprised of highly diverse landscapes (Table 17.1). The large, private ranchers focus on beef cattle, and they have access to land mostly situated in the most productive, semiarid grassland region. African forage grasses (i.e., Cenchrus ciliaris, Eragrostis curvula) have been introduced to boost rangeland productivity. A peasant class of pastoralists (ejidatarios) is found in the arid and semiarid hilly desert scrub (ejido) region where cattle, goats, and sheep can be herded in a traditional, seminomadic fashion; animals feed on native forage and crop residues. Ranches utilize cow-calf production systems based on grass forage. Steers are finished at large feedlots in preparation for export to the US. Animals produced in the ejido system are typically sold in local markets.

Livestock grazing pressure has been intense in Mexico since the arrival of the Spanish. Large portions of the semiarid zone have been subjected to nonirrigated cultivation, and deforestation has occurred. Multiyear droughts are common. Nearly half of the rangelands have endured severe soil erosion and woody encroachment due to heavy grazing and lack of fire (SEMARNAT 2005). Other trends include unfavorable shifts in land cover and plant species composition, including the expansion of introduced invasive species; this is most apparent in desert scrub ecosystems (SEMARNAT 2005). Climate studies indicate that precipitation patterns have been changing; warmer, drier conditions are expected (Piñeda-Martínez et al. 2007).

\subsection{Four Major Stewardship Themes for Rangelands of the Developing World}

We propose four major themes that are most vital to better understand how community-based organizations, traditional leaders, researchers, development practitioners, policy makers, and other change agents can help rangeland societies better navigate the challenges that face them. These themes are (1) pastoral land tenure and managing mobility; (2) sustainable rural livelihoods; (3) livestock development and marketing; and (4) conflict and crisis management. For each theme, we first frame the pivotal issues and conceptual advances and then provide supporting 
observations from the six case-study sites. We close with a synthesis and discussion of priorities for research and outreach.

\subsubsection{Pastoral Land Tenure and Managing Mobility}

Summary. One of the most unique aspects of pastoral production systems is the need for herd mobility. Mobility is required to optimally exploit an ever-changing landscape of forage production that is caused by high spatial and temporal dynamics in precipitation. Typically, as rangeland areas become more arid, the variability of precipitation in any one location increases; consequently, arid systems require more herd mobility than semiarid systems. This considers horizontal and vertical mobility, as the latter becomes important in places having marked elevation gradients. Access to diverse forage resources is influenced by multiple factors including availability of drinking water, physical insecurity, competition for land among various user groups, availability of herding labor, and restrictions imposed by land tenure regimes. The latter have traditionally emphasized flexibility and reciprocal user rights that enable pastoralists to better manage livestock production risks under fluctuating environmental conditions. Forage access has been traditionally managed under informal rules that underlie the use of communal resources; this can prominently include restricted access of producers to water or key forage resources during periods of resource scarcity. When rules do not exist or are ignored, environmental degradation due to open access can occur. Environmental degradation can also occur, however, due to other processes irrespective of management. Risks of environmental degradation are often used to justify state control over, or privatization of, communal grazing lands. The problem is that neither state control nor privatization can typically offer the creativity and flexibility required to foster reliable access to local or regional resources under highly diverse circumstances. Our six case-study sites share one major trend overall: herd mobility has declined in terms of distance and frequency almost everywhere. Common causes of declining mobility include territorial fragmentation of rangelands, poor rangeland governance, increased settlement of previously mobile pastoralists, and a gradual loss of herding labor due to herder emigration. In general, there is an increasing awareness at local, national, and regional levels of the need to restore or maintain herd mobility where possible, but overcoming key constraints can be daunting. One commonly shared view is that change agents can help restore herd mobility and flexible resource use in some situations by improving rangeland governance.

\subsubsection{Pivotal Issues and Conceptual Advances}

Forage production on rangelands is typically influenced by precipitation regimes that vary greatly over space and time. This requires pastoralists to be highly opportunistic, and mobile herds of livestock are precisely the harvesting tool needed to 
effectively exploit forage resources and mitigate the inherent risks of animal productivity. The more arid the rangeland system, typically the more mobile a pastoral society needs to be.

Many arid and semiarid rangelands are communal resources from which it is difficult to exclude potential users, but where use by the animals of one individual reduces the amount of forage remaining for the others. If there are no rules to determine who may graze, or to place restrictions on the amount, timing, or spatial distribution of grazing, the situation is termed "open access," and there is a risk of overuse and degradation (Ostrom 1990). Most rangelands are not open access; instead they are subject to some type of property regime-a set of formal or informal rules that define the rights and obligations of specific individuals or groups to access, use, manage, or transfer (sell or gift) a resource. Pastoral land tenure refers to the set of rules that define who may access, use, or manage land or other pastoral resources. In the developing world, many pastoral land tenure systems were traditionally based on well-established, albeit unwritten, rules in which communities held collective use and management rights to forage (Lane 1998). This form of tenure is called common property (Ostrom 1990).

Many of these traditional systems are now in transition to more formal systems in which common property becomes state property managed by government authorities, private property owned by individuals, or-less commonly-common property officially possessed and managed by a defined community of users through a formal legal agreement (Galvin 2009; Lane 1998; Toulmin 2009). ${ }^{25}$ In still other cases the state may have formal control over an area but lack the capacity to manage it effectively; much of the Sahel is "state property" in a formal sense, but the state has little influence over resource rights or use (Turner, personal observation). In the past, some development practitioners mistakenly believed that rangeland degradation was a result of common property systems and thus advocated greater government control or privatization of commons. Today we recognize that while open access (the lack of rules) can lead to degradation, ${ }^{26}$ communal property is often the most appropriate land tenure system in highly variable semiarid and arid rangelands where sustainable grazing management depends on pastoralists' ability to move their herds and have flexible access to heterogeneous resources across extensive land areas. Under these circumstances, dividing a large commons into many smaller private parcels is likely to lead to ecological degradation and increased vulnerability of pastoralists to climate risks like drought or severe winter weather (Galvin 2008).

\footnotetext{
${ }^{25}$ Central governments, following the precedent set by colonial regimes of claiming ownership of rangelands and weakening traditional (tribal) authority over land use, may set up appropriate regulations for land management but have neither the incentive nor the personnel to enforce those regulations. One result has been less control over local land use and hence more degradation. The main remedy is to return to some form of local authority, with or without government participation. One solution has been to establish government-instituted local authorities for land management that operate in parallel with traditional (tribal) leaders. The challenge then is to find mechanisms to ensure that both actors work together.

${ }^{26}$ Sites having high variability of forage and water can lead to shifting grazing patterns with little potential for overgrazing in systems that lack formal rules (Turner, personal observation).
} 
Alternatively, dividing rangeland into a few very large, ecologically viable private parcels is not socially viable because large numbers of residents would be displaced.

Nevertheless, solving the dilemma of pastoral land tenure is not simple because herders need both secure access to local key resources such as dry season or winter pastures and flexible access to distant pastures during disasters, and it is difficult for most formal land tenure systems to meet both of these requirements simultaneously (Fernández-Giménez 2002; Turner 2000). Formalizing tenure by allocating exclusive rights over key resources assures security, but may limit flexibility. Allowing maximum flexibility may result in lack of secure rights to key pastures for some herders, when others come to use their pasture during a disaster. In any location it is important to understand the historical, environmental, and sociocultural context for the existing land tenure system, its strengths and limitations in meeting pastoralists' needs for security and flexibility, its potential to support increased or sustained economic activity, and its compatibility with land health and wildlife conservation goals (Turner 2000).

When tenure systems change, there are always winners and losers, and thus the social equity consequences of changing tenure must also be considered. Historically, pastoralists have often been dispossessed of their traditional grazing territories when their lands, designated as "vacant" or "wasteland," were seized by the government for conservation (e.g., national parks) or economic development (i.e., mining, cultivated agriculture, renewable energy production) purposes. There is no onesize-fits-all tenure system that assures economic productivity, environmental sustainability, and social equity, but many systems have evolved in different regions that enable productive use of rangelands compatible with sustaining land health and meeting conservation goals. These may be based on common property regimes or, increasingly, a mosaic of private, public, and common property resources (Galvin 2009; Toulmin 2009; Turner 2000). The key is that when development reduces the effectiveness of previous controlling factors for rangeland access and use, it is vital that new controlling factors are created and adopted by the community.

\subsubsection{What Has Been Observed?}

Afghanistan. As noted above, Afghan pastoralists must migrate seasonally from low-lying areas in the winter and spring to higher elevation sites in summer-a pattern that tracks the availability of green forage as the snow melts. This pattern has been disrupted repeatedly over the past century. The most recent disruptions have included the Soviet occupation (1979-1989) and subsequent periods of ethnic unrest, civil strife, insurgencies, drought, government land annexation, corruption, and class conflict. A lack of regulatory institutions and development investment has compounded the problems. Individually and collectively, these forces have had very negative effects on pastoral common property management regimes as well as on the resource use by non-pastoral groups in Afghan society (Barfield 2004; Jacobs and Schloeder 2012; Wily 2013). 
For the Kuchi, one outcome has been a marked reduction in livestock mobility and animal health (Jacobs et al. 2009). In response to landscape fragmentation, some pastoralists are now hiring trucks to move their animals between spring and summer range in an effort to avoid either having to pay for grazing rights, finding that their leases are no longer honored or available because key lands have been cultivated, or risk of losing animals to criminals or corrupt officials. This option for trucking is only available to wealthier individuals or clans, however, leaving the less affluent highly vulnerable to complete herd losses. Others who have already lost their animals hire out as long-term herders for wealthier pastoralists with the agreement that profits are shared between the herder and owner when certain animals are sold.

In the last decade there has been some progress towards addressing the country's environmental, social, and economic challenges. This includes endorsing the Millenium Development Goals and the implementation of the Afghanistan National Development Strategy. Land-use policy, on the other hand, has been slow to evolve. Consequently, the land rights situation has worsened rather than improved since 2001 in most rural areas (Wily 2013). As rangeland becomes increasingly unavailable due to unchecked forces previously described - as well as the failure to address historic grievances-poverty and food insecurity for the Kuchi will grow further because those still herding will increasingly find that they are unable to meet their most basic needs for survival (Jacobs and Schloeder 2012).

While an increasing population has resulted in more grazing pressure on rangelands - particularly close to villages - probably the greatest impact to extensive livestock production after years of conflict has been the loss of relationships between herders and the villagers they encounter during their annual migrations. Decades of fighting have left very little trust among people. Herders who may have had strong, traditional relationships with villagers are now met with unfamiliar, fearful, mistrusting people nervous about herders moving past their villages. Both the herders and villagers are well armed, making the situation tense and ripe for land-access conflicts. This insecurity has not only restricted the movements of livestock but is threatening the survival of this highly evolved animal production system. Implications affect industries dealing with meat, dairy, hides and skins, wool, and carpet making.

Ethiopia. In southern Ethiopia, local and regional human population growth has had more negative effects on traditional common property management and herd mobility than has land annexation by outsiders (Desta and Coppock 2004). Human population growth drives the need for more food, be it milk from livestock or maize from cultivation. This, in turn, increases the competition for forage and land, manifested in the creation of privatized grazing sites (kalo), expansion of cultivated fields, and demise of traditional fallback areas that were once used for grazing during droughts. This fragmentation reduces herd mobility and pastoral resilience to drought (Desta and Coppock 2002, 2004). Grazing management can be conceptualized as traditionally occurring within several nested levels of spatial resolution. From higher to lower resolution, these are (1) olla, (2) arda, (3) rera, and (4) dedha. These vary in size from square kilometers (olla) to tens of thousands of square kilo- 
meters (dedha). Traditional grazing managers and water managers for the Boran have customarily overseen the integrated use of these strata; creativity and flexibility are needed to effectively balance forage supply and demand every year.

In the past 20 years, however, the traditional system has been augmented by pastoral associations (PAs) which are governmental administrative and political units; PAs have become involved in resource-use decision making, and contestation of authority between traditional and PA institutions has led to problems (Homann et al. 2008). Resource fragmentation problems now occur at all spatial levels, while another challenge at the most local level is ultimately an inability to control stocking rate, and hence forage utilization (Tezera et al., unpublished data). Annual rates of forage utilization among four PAs have been estimated to vary from 70 to $90 \%-$ one outcome of such heavy use is soil erosion and bush encroachment, as previously noted. Coping with such challenges has largely been left up to the traditional leadership of the Borana pastoralists in concert with decision makers from government agencies, but it is evident that population pressure, emergence of very wealthy pastoralists, and reduced adherence to traditional pasture-use norms have undermined grazing regulation in recent decades.

Progress, however, is being made on several fronts. This includes (1) finalization of a land-use plan by government that should limit cultivation on grazing lands; (2) efforts to restore traditional grazing access beginning at the dedha scale of resolution; and (3) workshops to address the need to reduce stocking rates and limit forage utilization at the local level to help arrest rangeland degradation. Thus, there are opportunities to assist pastoralists to update traditional grazing rules and regulations to better accommodate the new reality of higher demand on natural resources. Increasing scarcity of surface water and forage is recognized by pastoralists as a critical problem that merits new, collaborative approaches for problem solving (Coppock et al. 2014).

Sahel. In the Sahel, pastoralists exploit the high variability of rainfall across space and time via highly mobile livestock. ${ }^{27}$ Population growth, land-use change and resulting land fragmentation, and unfavorable policies, however, have contributed obstacles for herd mobility at local and regional scales. Traditional pastoral institutions facilitated access to constantly shifting patches of natural resources (de Bruijn and van Djik 1995; Niamir-Fuller 1999). Colonial and postcolonial land policies, however, ignored pastoral rights and this, coupled with socially malleable rights to pastoral resources among pastoral groups, has made pastoral resources vulnerable to competing land uses, especially with the rapid growth of human populations since the 1950s (Guengant et al. 2002).

Since the 1990s, programs to decentralize natural-resource management authority, as well as recurrent attempts to privatize land, have contributed to the enclosure of key pastoral resources (Marty 1993). While these changes have generally not caused widespread sedentarization of pastoralists and their livestock, they have reduced mobility, altered movement patterns, reduced livestock access to grazing,

\footnotetext{
${ }^{27}$ The movements of pastoral livestock are organized in response to long-established seasonal and spatial criteria that also allow for local tactical adjustments (Hiernaux, personal observation).
} 
water, and mineral resources, and increased conflicts (Turner et al. 2014). There is growing recognition within policy circles of the importance of the livestock sector and livestock mobility, especially in the context of climate change (Bonnet and Hérault 2011). This has led to national (République du Mali 2001; Wabnitz 2006) and international (CRCM 2013) laws, policies, and agreements in support of pastoral livelihoods and tenure rights. These initiatives are important, but they alone cannot lead to a significant transformation of pastoral rights. Significant political and institutional questions have to also be addressed for effective implementation (Brottem 2013).

In general, local understanding and enforcement of existing laws are weak. Some newly organized formal community-based rangeland management groups have creatively circumvented these challenges by working closely with their local government to obtain use rights over defined pasture areas, create their own management plans, and then lobby local government to pass an ordinance or decree that gives certain elements of their plan the force of law (Fernández-Giménez et al. 2012; Upton 2008, 2009). For example, if a group of herders wants to rest a certain pasture area for a season, they ask the local government to issue an edict forbidding grazing in that area for the rest of the season, with violations punishable by a fine. ${ }^{28}$

Mongolia. The pasturelands of Mongolia are state property used in common by the herders within a given administrative district. Privatization of pasture is unconstitutional, but herders may obtain long-term private leases on nomadic winter and spring campsites (Fernández-Giménez and Batbuyan 2004; Upton 2009). Mongolia's Law on Land contains provisions related to pastureland tenure and management, devolving most decisions and authority to regulate stocking rates and seasonal movements to the local level (Fernández-Giménez and Batbuyan 2004). Under Mongolian law, organized groups of herders may obtain collective use agreements for defined areas of pasture, but "use" does not denote the right to exclude other potential users. Pastureland "possession" would confer exclusive rights to a given pasture area, but pasture possession is not authorized under the current law.Mobility has been a hallmark of Mongolian pastoralism for centuries and continues to be an important strategy today. Mobility patterns historically have varied widely across the country, depending largely on local topography and climate. During the collective era, the collectives allocated pasture to their member herders and both regulated seasonal movements and provided transportation for moves (Fernández-Giménez 1999). In addition, collectives arranged for long-distance moves in weather disasters such as severe winter storms. Following privatization of livestock and the dismantling of collectives, no formal institutions have filled the role of allocating pasture and enforcing seasonal mobility, although the current law

\footnotetext{
${ }^{28}$ Over the last two decades, multiple proposals have been made for a national pastureland law, but none has reached a vote in parliament. Debates on the proposed laws continue over the central tension between authorizing formal possession rights in pasture for groups of herders or individuals with the risk of reducing access and flexibility for some and keeping the current vague, but flexible and locally adaptable, system in place.
} 
gives this authority to local governments. As a result, mobility has decreased in many areas, and conflicts over pastures have increased, together with unsustainable season-long grazing in some areas (Fernández-Giménez 2002).

When disasters such as prolonged drought or severe winter weather strike, many herders undertake long-distance movements to escape these conditions and create pasture shortages at their destination (Fernández-Giménez et al. 2012; Upton 2012). Flexibility to make these movements in response to disaster is essential to the sustainability of this system, but lack of coordination and cross-jurisdictional governance mechanisms create hardships for herders in the host communities as well as exacerbate pasture degradation problems.

Altiplano. In the Altiplano, the loss of labor for herding and irrigating the bofedales has been the major contemporary factor in reducing the mobility of range livestock (Turin and Valdivia 2011). Privatization of key resources has also occurred. One example is fencing off parcels of bofedale that were formerly communal grazing sites for the exclusive use of a few alpaca producers (Buttolph and Coppock 2001). Ninety percent of Andean rangelands, however, remain as public land accessed by rural communities, but there are persistent challenges of landscape fragmentation and privatization due to human population encroachment, especially in Peru. This can lead to local limits on herd mobility and thus rangeland degradation (Turin, unpublished data). In some cases highly dynamic land tenure systems have been discovered in Bolivian agro-pastoral settings. For example, pastures used for sheep grazing in the vicinity of San José Llanga are traditionally regarded as private-access sites in higher precipitation years, while they become communal sites in drier years (Coppock et al. 2001).

Mexico. In northern Mexico, a gradual process of livestock commercialization and land-use fragmentation has also reduced livestock mobility. In the past there was a large-scale transhumance of livestock in the region, but today this has been replaced with local movements of beef cattle from private rangelands to private croplands at the end of the growing season to harvest crop residues (Martínez-Peña 2012). As previously noted, goat and sheep herding by ejidatarios occurs on desertscrub (ejido) land; animals are trekked on long-distance orbits. Following recent agrarian reforms, some ejido lands, however, are now shared among a few ejidatarios having certain privileges to own land, and this has caused land to become fragmented and fenced. These land users, however, are forced to establish earthen ponds to supply water for cattle, fundamentally altering hydrological processes at the landscape scale (Huber-Sannwald et al. 2012).

The ejido system comprises roughly $54 \%$ of Mexican rangelands today and is the most common form of land tenure (Arredondo and Huber-Sannwald 2011). The ejido concept originated in the Mexican Constitution of 1917 as a postrevolutionary, communal land-management institution. Ejido governance is idiosyncratic, depends on the local biophysical and socioeconomic context, and is largely independent of federal funding support. For decades ejidos were subject to strict regulations specifying that only ejidatarios can use the land for agrarian purposes and that the land cannot be sold, rented, or mortgaged. Changes have occurred in the ejido system over the past 20 years, however. 
In 1992, a Constitutional Agrarian Land Reform was passed allowing ejidatarios to assume full domain over their communal land with the right to divide and sell it (DGAHML 2003). One motivation for this reform was to introduce a mechanism for wealthy ranchers to appropriate communal land, introduce technology and new livestock breeds, and enhance livestock production to improve Mexico's position in global markets (Martínez-Peña 2012). However, adoption of this neoliberal policy has not translated into the expected, massive privatization of ejido lands. Possible reasons include the following: (1) that some ejidal assemblies preferred to maintain communal lands as such (DGAHML 2003), or (2) because communal lands were unattractive to wealthy ranchers because of inadequate resources or remoteness (Manzano et al. 2000). The risk of privatization and fragmentation of prime ejido lands still exists, however, and this risk is primarily related to the potential displacement of residents who could otherwise make a sustainable living on the landscape. In the course of the "private revolutions" during 1937-2007, private ranchers have managed to consolidate and expand their ownership of land by giving cattle to their wives or children. Private land holdings include anything from small (300-1000 ha) to mega (>10,000 ha) ranches.

\subsubsection{Sustainable Rural Livelihoods}

Summary. Sustainable livelihood concepts were first introduced nearly 30 years ago. Significant advances in defining terms and integrating ideas concerning sustainable livelihoods into research and development projects are more recent, however. Livelihoods are founded on production strategies. A livelihood is sustainable when it allows an individual or a household to rebound from an economic or ecological shock. Various resources are drawn upon in a recovery process. Increasing and diversifying income and assets are core processes that help livelihoods become more sustainable in risky environments. Pastoral societies have also traditionally had safety nets linking relatives and neighbors where people who have suffered from a calamity can receive animals to restock themselves. Rangeland dwellers such as pastoralists or agro-pastoralists are the epitome of risk managers who have survived droughts and economic downturns via traditional tactics. These tactics have included a high reliance on mobile livestock as well as participation in social networks that provided safety nets and allowed for the opportunistic and reciprocal use of communal resources. While livestock production remains a core strategy in all of our case-study sites, it has become increasingly difficult for most pastoralists to survive from livestock alone. This is due to increases in the numbers of people and reductions in the numbers of livestock per family due to declining supplies of forage and other natural resources; the forage base simply cannot keep up with the growing numbers of animals required to sustain an expanding human population. As a result, many research and development efforts today emphasize ways to build capacity and assist rangeland dwellers to diversify their livelihoods away from too heavy a reliance on livestock. This often involves participatory activities. 
Diversified livelihoods can pose their own risks and are not a panacea for all, but they offer a chance for more people to be hopeful and pursue some prosperity in a rapidly changing world.

\subsubsection{Pivotal Issues and Conceptual Advances}

Sustainable livelihood concepts first began to be addressed as part of mainstream research and development in the 1980s. They arose from a need to better understand interrelationships of people with natural resources and to help chart pathways for poverty reduction and social justice in the developing world (Martens 2006). In the 1990s, conceptual progress was made in terms of articulating components of sustainable livelihood frameworks (Chambers and Conway 1992; Scoones 1998; Singh and Gillman 1999). A livelihood is sustainable when it allows an individual or a household to recover from an internal or external shock; the ability to recover from a shock is referred to as resilience. Livelihoods draw on various capital assetssocial, human, financial, physical, and natural - as people pursue production strategies that involve intensification, extensification, or diversification. ${ }^{29}$ Increasing and diversifying income and assets are thus means to promote sustainable livelihoods.

Pastoralists and agro-pastoralists provide useful models for the study of sustainable livelihoods because they are the ultimate risk managers. Subjected to the impacts and unpredictable occurrence of drought, disease, social conflicts, and economic crises, pastoralists have traditionally managed risk via several avenues (Coppock 1994). These have included (1) opportunistic exploitation of vast landscapes by mobile livestock; (2) reliance on a diverse assortment of livestock species; (3) opportunistic engagement in cereal cultivation or petty trade; (4) membership in complex social-reciprocity networks that offer safety nets during times of stress as well as a means to restock following herd collapses; and (5) use of grazing reserves or fodder storage. The problem, however, is that steady human population growth, annexation of key pastoral resources, assertion of government control over national and regional borders, recurrent drought, or other extreme weather events have undermined such coping mechanisms.

In some pastoral systems, pastoralists periodically "drop out" of the pastoral economy-often following drought or other weather-induced disasters-because they can no longer support themselves via traditional means. These former herders reside in settlements or urban areas and survive via relief food, petty trade, or other occupations. This often happens to pastoral women (Holden et al. 1991). In some situations dropouts may eventually return to pastoralism, but in others they make a

\footnotetext{
${ }^{29}$ Intensification characterizes high-input systems and involves investing capital, labor, and other resources in land or animals to increase per unit productivity. Extensification, in contrast, characterizes low-input systems and involves expanding the land base or animal numbers to increase overall operational output. Diversification is a process of expanding the types of enterprises undertaken by an operation, leading to more variation in income sources or assets.
} 
permanent exit. ${ }^{30}$ While sedentarization of former pastoralists is typically maligned as negative for environmental management, human nutrition, and maintenance of pastoral culture (Fratkin and Roth 2005), a growing pool of settled people can offer opportunities to educate people and build capacity for people to engage in collective action to diversify livelihoods and pursue non-pastoral lifestyles (Coppock and Desta 2013). There are also cases where households pursue mixed strategies by having some members maintain livestock in the pastoral sector with others engaged in urban economies.

\subsubsection{What Has Been Observed?}

Afghanistan. In Afghanistan, few pastoralists are able to depend solely on livestock production for a livelihood. Livelihood diversification is the key to success, particularly on a landscape predicted to experience drought on a more frequent basis in the future. Women should be encouraged to contribute to livelihood diversification in areas acceptable to the family (i.e., carpet weaving, dairy production, small animal husbandry).

One conceptual advance that has helped change agents in Afghanistan to think more clearly about their work has been to encourage communities to communicate and self-advocate more effectively. This is because management of any natural resource has little chance of being successful without including the people most impacted by the process. Until change agents can fully engage local people and understand their challenges and aspirations, imposing top-down management strategies will most likely fail. The typical approach in Afghanistan has been top down; donors support government ministries to develop rural strategies without any community participation. This is justified by arguments that the rural poor lack the education or wisdom to "know what they want" and because in most instances community involvement takes longer than the donor or government is willing to wait. Successful projects, in contrast, are those where a healthy dialogue is developed between the change agents and project beneficiaries, and both are willing to make the time needed for meaningful interaction. The vital role of the change agent then becomes assisting communities to better articulate their challenges, needs, and aspirations, providing professional guidance and "reality checks," and making the commitment to support a long-term process. Once there is a commitment and community members become skilled communicators and self-advocates, they will then have the ability to resolve, or at least better manage, conflicts with neighbors and effectively engage government agencies. ${ }^{31}$

\footnotetext{
${ }^{30}$ The specter of periodic waves of permanent dropouts occurring within dynamic production environments is universal for farmers, ranchers, and pastoralists in developed as well as developing countries (Thurow, personal communication).

${ }^{31} \mathrm{~A}$ blend of bottom-up and top-down is therefore the prescription; despite the importance of hearing community voices, people cannot ask for things that they cannot imagine-hence the role of outside knowledge and demonstration activities. Fruitful engagement is also greatly promoted by simply having more time for change agents and communities to interact and make the correct decisions. Time constraints are ultimately imposed by the short-term funding cycles that characterize most development projects today.
} 
Ethiopia. In southern Ethiopia, traditional pastoralism is no longer a sustainable livelihood for the vast majority of households given sharp declines in the number of livestock units per capita, as previously noted. Another trend is a steady increase in wealth concentration - fewer people own more of the aggregate cattle herd, for example (Coppock et al. 2014; Desta and Coppock 2004). Over $40 \%$ of the population now have only a few head of livestock per household and are caught in a perpetual poverty trap. ${ }^{32}$ Traditional safety nets have been tattered, and food aid has become pervasive in much of the system because milk production can no longer meet the basic needs for a growing segment of the population. One option to improve the welfare of the poor is to encourage livelihood diversification via microfinance and collective action activities-programs that can inspire women, in particular (Coppock et al. 2011).

Sahel. In the Sahel, key features of livelihood strategies in this resource-poor and highly variable region are diversification, mobility of production, and wealth stores (Agrawal 2008). As described above, livestock, as mobile stores of wealth which are not vulnerable to local deficits of rainfall (unlike crop agriculture), figure prominently in the livelihood strategies of all rural people whether their identity is tied to farming, commerce, fishing, or livestock husbandry (Turner et al. 2014). Thirty years of recurrent drought have increased the diversification of economic activities within rural households. Farmers will own livestock and livestock producers will farm and all, if they are able, will send family members on a seasonal or semipermanent basis to work in cities, mines, and plantations to the south (de Bruijn and van Djik 1995; Turner et al. 2014).

Differential vulnerabilities to economic and climatic shocks are observed not only between families but within families, with women being particularly vulnerable (Creevey 1986; Gray and Kevane 1999; Turner 2000). Livestock play an important role in addressing such vulnerabilities as individually owned wealth stores, owned separately by women and men, which have an additional benefit of being not easily fungible to cash and therefore less vulnerable to being dissipated by daily demands for small amounts of cash from family and friends (Turner 2000). ${ }^{33}$

While case studies illustrate the reliance on livestock by rural families, they also point to the limitations of livestock ownership in buffering household income in response to episodic climatic and economic shocks. Livestock prices predictably decline in relation to grain prices during periods of food shortage (e.g., the hunger season at the end of the rainy season prior to the next harvest) and decline precipitously, in a less predictable manner, during drought (Fafchamps and Gavian 1997; Watts 1983). As a result, the effective wealth stored in livestock depends on when they are sold in relation to annual and drought cycles of grain shortage.

\footnotetext{
${ }^{32} \mathrm{~A}$ poverty trap is a spiraling mechanism which forces people to remain poor. The mechanism is binding such that poor people cannot escape it; it is often caused by a lack of capital or credit for people who also have no prospects for employment.

${ }^{33}$ Such problems are also exacerbated by inaccessible or unreliable financial institutions in the rangelands of developing nations. Investing in livestock thus becomes the most viable alternative, despite the sometimes high risk of animal death losses.
} 
Modeling work based on retrospective surveys in the Dantiandou study site (Lesnoff et al. 2012) demonstrates the limited potential for livestock wealth recovery among sampled families. This is not only due to recurrent drought over the past 30 years, but also due to other extreme events (i.e., livestock disease epidemics) and the generally low productivity of livestock husbandry due to the limited access to pastoral resources (land-use change, civil insecurity, etc.) aggravated by the poor access to and high cost of inputs (i.e., veterinary drugs, feed supplements).

Mongolia. In Mongolia, following the transition to a market economy, poverty in rural areas increased dramatically, and the gap between rich and poor widened (Griffin 2003; Nixson and Walters 2006). Many development programs have sought to address this through a variety of income-generation and diversification measures; however, progress has been slow due to a number of limitations to livestock improvement and marketing (see section below). The most common approaches to income diversification are small-scale vegetable growing, value-added processing such as felt making and handicraft production, and small-scale enterprises such as shop-keeping, trading, driving, or collecting rent for properties in nearby settlements. Felt making has a limited market that is rapidly saturated. Artisanal mining, primarily for gold, is the most important source of income diversification in recent years. In a recent household survey in 36 districts, respondents in 10 reported income from mining. In these districts from $10 \%$ to over $50 \%$ of surveyed households obtained some income from mining (MRRP, unpublished data). Over the long term, payment for ecosystem services and sustainability certification seem to be among the most promising approaches that directly build on livestock-based livelihoods, but these are still in their infancy.

Altiplano. For the Altiplano, multiple factors explain the diversity of livelihoods and livelihood strategies. The roles of livestock in livelihoods change with elevation, geography, climate, and distance to markets (Valdivia et al. 2010). An example of a high degree of livelihood diversification is provided by the agro-pastoralists of San José Llanga in the central Altiplano (Valdivia 2001). Such households are typified by activities such as growing potatoes, oats, native tubers, and quinoa, as well as raising sheep for meat and wool and cattle for meat and dairy. Off-farm employment comprises additional activities. Men and women divide labor responsibilities on the farm, with men assuming the more demanding physical activities (i.e., cattle breeding and planting and harvesting crops). Women are in charge of herding and milking animals as well as selecting seeds and making planting decisions. Women also oversee cultural events. The process of livelihood diversification and market integration at San José was initiated by investments in infrastructure (transportation and irrigation), extension of production technology (i.e., alfalfa, crossbred dairy cows), and government decentralization policies that facilitated market development (see next section). Dairying has contributed to managing risks of the overall economic portfolio because it provides access to cash on a monthly basis. When there is a drought or frost and a potato crop is lost, for example, farmers can use the earning from the dairy cows to obtain new seeds and plant. When barley and oats are lost to drought, the stubble still provides a feed source for the livestock (Valdivia 2004).

An example of less diversified pastoralism is provided by the Apopata community at high elevations in the Peruvian northern Altiplano (Turin, unpublished data). 
Primary livestock products among pure pastoralists are alpaca meat and fiber; nonlivestock endeavors include off-farm employment, handicraft production, fishing, and harvesting wood of shrubs for fuel. Price incentives dictate the degree of market involvements. Men and women have complementary roles in alpaca pastoralism, as men handle the shearing, breeding, and marketing as well as provide oversight of pasture irrigation systems. Women herd and provide health care for animals and cover domestic chores. When men migrate in search of work, however, women assume the tasks typically undertaken by men (Turin et al. 2010; Valdivia et al. 2003). In both Andean pastoralism and agro-pastoralism, traditional social networks have been very important to help manage economic and climate-related risks. These networks have been supplemented of late with new government partnerships whereby herders can direct public investments to best serve local needs. For example, in the Peruvian municipality of Mazocruz, pastoralists have led the way on decisions to use public monies to build livestock shelters (cobertizos) that markedly reduce losses of camelids during periods of extreme cold (Turin, unpublished data).

Mexico. In northern Mexico, the main livelihood of people living in the drylands is ranching. Some diversify with mining activities, wage labor in nearby towns, seasonal migration, and remittances from migrants. The latter is a trend of the younger generation who seek alternative lifestyles. Subsistence farming with extensive and semi-intensive livestock production (i.e., cattle, sheep, and goats) and rainfed agriculture are the main economic activities in the region (INEGI 2002). For the last 3 to 4 decades, government assistance programs have opened alternative production opportunities for ejidatarios. Seed money or crop seedlings are provided to engage in planting programs of plantations of opuntia for vegetable and tuna fruit production for local markets. Also, in some villages professional music groups (Mariachi, Banda, Trios) have formed. In matorral-dominated rangelands, the government has locally supported the collection and processing of "ixtle," a strong, high-quality fiber extracted from the leaves of wild populations of Agave lechuguilla, for the brush-making industry. In central and northern Mexico, some ejidatarios collect wild plants of Agave salmiana and Dasylirion wheeleri to supply mezcal and sotol distilleries. Also, to reduce illegal trade in rare cacti, the government has helped install greenhouses for commercial cactus production. More recently, leasing ejido land to foreign wind farm companies has emerged as an alternative income generator for some ejidatarios.

\subsubsection{Livestock Development and Marketing}

Summary. Livestock development can be defined in several ways, including the process of sustaining or increasing livestock outputs per capita, or in terms of addressing multiple societal goals to improve the livelihoods of livestock producers whose ranks tend to be dominated by the rural poor. The developing world is currently undergoing a "livestock revolution," whereby increasing consumer incomes and rates of urbanization spur a demand-driven surge for high-value animal 
products such as milk and meat. This supply can be met, in part, via the commercialization of subsistence agriculture. Rural livestock producers in both farming and pastoral systems should benefit from this trend, but pastoralists must overcome more obstacles to do so simply because they tend to be more isolated from major centers of consumption. A transition from subsistence to commercial practices for pastoralists can be painful as it yields winners and losers; it will prominently involve overcoming high transaction costs for livestock marketing. Barriers to commercialization include the need to transform the quality and types of animals and animal products produced, as well as the need to upgrade transportation infrastructure, communication networks, and other marketing infrastructure such as slaughter facilities and holding grounds. The need to not have a region classified as a disease quarantine zone preventing export is also vital. The boom-and-bust pattern of herd population dynamics often observed on rangelands also conflicts with the need for stability in market supply required by modern animal-processing industries. An overview of our six case-study sites reveals that most pastoral herds remain dominated by indigenous breeds with a low per head productivity, but these animals are durable when facing endemic disease, poor nutrition, and harsh environmental conditions. There is evidence of increased market participation in most of our cases, but levels of sustained livestock market development vary greatly. Use of mobile phones to transmit market information has become ubiquitous in the past decade - this is a major success story. The best examples of demand-driven range livestock development, with attendant changes in livestock policies, the upgrading of indigenous livestock via crossbreeding, and use of increased production inputs, may be found in two of the case-study sites in the upper tier. These are (1) the expansion of peri-urban dairy and wool production among agro-pastoralists in the Bolivian Altiplano and (2) the rapid growth of commercial beef production among ranchers in northern Mexico.

\subsubsection{Pivotal Issues and Conceptual Advances}

"Livestock development" is defined in several ways. In its simplest form, it can be described as the maintenance or enhancement of livestock output, preferably expressed on a per capita rather than per hectare basis (Jahnke 1982). More recently, livestock development has been defined as a process of addressing interrelated socioeconomic, environmental, and productivity goals that would reduce poverty among people who raise livestock for a living. ${ }^{34}$ Others have noted contributions of livestock to food security and sustainable development (Sansoucy et al. 1995).

Worldwide, it is clear that as rates of urbanization accelerate and societies gain wealth, one of the first things to follow is an increased demand for animal-based foods. With more income, people reduce their intake of less expensive carbohydrates and increase intake of more expensive animal protein, including milk and meat (Delgado 2003). This relationship is the linchpin of a projected "livestock revolution" for the early twenty-first century as populations in developing countries

\footnotetext{
${ }^{34} \mathrm{http}$ //www.fao.org/ag/againfo/programmes/en/pplpi/docarc/rep-ipalp_ldg.pdf
} 
become more urbanized and economies expand. There should be a concomitant opportunity for livestock producers to meet this growing demand (Delgado et al. 2001). A "traditionalist" might contest the assertion that pastoralists need to become more commercialized, given the downside risks of market participation. Yet it is clear today that most rural agriculturalists - whether they be smallholder farmers or pastoralists - have to commercialize and join the cash economy given that they can no longer survive in a pure subsistence mode (Fitzhugh, personal communication). ${ }^{35}$

Who has, or will, benefit from market growth varies, however. Livestock producers who inhabit remote rangeland areas of the developing world are expected to benefit less than other livestock or dairy producers, simply because the socioeconomic and geographic isolation inherent for most rangelands increases the transaction $\operatorname{costs}^{36}$ for efficient market participation. There are many barriers for livestock marketing transactions in the rangelands for both buyers and sellers (Holloway et al. 2000; McPeak and Little 2006; Sandford 1983; Zant 2013). Barriers include things like poor roads, lack of transportation, inadequate holding grounds or slaughter facilities, inefficient communication on prices, limited access to banking services, tax policies creating disincentives for cross-border trade, overabundance of middlemen in marketing chains, illiteracy, and lack of legal protections. The objective of much research in applied economics on rangelands today is discovering ways to help producers overcome or mitigate high transaction costs (Valdivia, personal communication). Mitigation of transaction costs increases market efficiencies and promotes market integration (Valdivia 2004).

There are other barriers that slow livestock commercialization on rangelands that are not immediately related to market transactions per se. One is related to traditional values and needs among pastoral people. For example, the sex and age composition of pastoral livestock holdings have long been shaped by cultural or risk management goals rather than commercialization goals (Coppock 1994; Fafchamps and Quisumbing 2005; Valdivia 2004). The upshot is that the mix of animals supplied by pastoralists in terms of age, size, or body condition can be suboptimal when compared to urban consumer preferences driving demand (Desta et al. 2006). ${ }^{37}$ In addition, the dynamic nature of livestock inventory in pastoral regions - previously

\footnotetext{
${ }^{35}$ Most pastoralists have been integrated into a market economy to some degree for decades. In reality there is a continuum between pure subsistence pastoralism (which is rare today) and pure commercial production (also rare today). Most pastoralists in the developing world will continue to produce for both self-consumption and markets, but if market signals were stronger in rewarding quality over quantity, this could alter incentive structures and transform pastoral livestock systems. And market integration for producers has both positive and negative dimensions, positive in terms of income generation and price stabilization, yet negative in terms of adding risk exposure.

${ }^{36}$ Transaction costs include the added time, effort, and expense associated with making an economic exchange (i.e., selling or buying).

${ }^{37}$ For meat, consumers often demand animals of a certain age, sex, and size. If leather making is a consideration, consumers often demand unblemished hides and skins. For milk, consumers should demand undiluted, hygienic products. Slaughterhouses may also demand uniform size-classes for processing as well as demand disease-free animals. In the latter case, disease imported to a slaughter facility by range stock could lead to a shutdown if discovered by health inspectors.
} 
noted as often weather-related, boom-and-bust cycles - creates big problems for processing industries further up the value chain that require stability of product flows to stay in business.

Another key issue in livestock development concerns livestock breeding. The rangelands of the developing world have long been populated by indigenous breeds of multipurpose cattle and small ruminants. Although such breeds are not very productive on a per head basis, they are nonetheless well adapted to survive in harsh environments that include shortages of feed and water, disease challenges, and temperature extremes. Improved (e.g., European or exotic) breeds often have the opposite attributes, namely higher productivity but increased vulnerability to stressful environmental circumstances (Coppock 1994; Kosgy et al. 2006). Crossbreeding indigenous with improved stock has occurred on a limited basis, and the typical outcome has been that crossbred animals cannot be sustained under indigenous rangeland production conditions. In the past 20 years the mantra has shifted to goals that include the conservation of breeds indigenous to rangelands and other environments.

Overall, it is fair to say that livestock development is like a three-legged stoolyou cannot put up one leg, then another, and then another and expect the stool to stand in the process. The legs of the stool must come together simultaneously. Why should a private investor attempt to improve market infrastructure if the supply is dominated by underweight or diseased livestock? Why should livestock production improve if there is no market to encourage the effort and offset the extra costs? The problem is that pulling off such coordinated projects is very expensive and time consuming, something most donor agencies don't have the mechanisms in place to provide. As a result, in most cases, livestock development occurs in a series of stutter steps, as will be illustrated.

\subsubsection{What Has Been Observed?}

Afghanistan. Commercial livestock production among the Kuchi remains constrained by the lack of financial inputs and chronic political instability. Livestock marketing, however, is vital to helping the pastoralists meet their annual needs for cash income (Schloeder and Jacobs 2010). The livestock holdings of the Kuchi are dominated by five breeds of indigenous sheep (i.e., Qaraqul, Turki, Qaragh, Arabi, and Baluchi) and two breeds of goats. The species and breed that predominate in any given region is a function of ecological constraints, the most important being disease resistance, water availability, and forage quality.

Recent trends indicate that-as animal numbers dwindle-more must be sold to meet basic family needs. ${ }^{38}$ Sales can start as early as May but are most common in the fall when market prices are highest (Schloeder and Jacobs 2010). Sales are also common during drought when there is a need to purchase food and other household

\footnotetext{
${ }^{38}$ Ten sheep per family member is reported as a minimum by Thompson (2007).
} 
essentials, even as animal prices plummet due to the influx of animals to markets. In either event, the increased need to sell will ultimately decimate herds over time. It will also result in an ever-greater dependency of the Afghan nation on meat imports.

Access to live-animal market information is critical for informed decision making by the Kuchi. Currently, the Kuchi rely on family members and other sellers attending markets for current prices (Schloeder and Jacobs 2010). Final sales price is the result of negotiations between the buyer and seller, with price a function of animal type, breed, age, sex, and body condition. Mobile phones have improved the ability to acquire current market information except in the more remote places where summer grazing occurs and phone coverage is limited. Additionally, producers are often unaware of prices in terminal markets where animals are often resold at much higher prices by traders. A Livestock Market Information System (LMIS) was established in 2008 by Texas A\&M University, in partnership with the Afghan Government, to overcome this challenge. Apathy on the part of government partners, however, in ensuring observer attendance on market days and collecting reliable price data undermined the program, despite high interest from producers and traders (Schloeder and Jacobs 2010).

Animals brought to market in Afghanistan are often underweight and diseased. Most of these problems can be overcome with quality medicines and a 1-month intensive feeding program, which adds considerable value per animal (Schloeder and Jacobs 2010). Unfortunately, the Kuchi lack reliable access to effective veterinary supplies. Additionally, pastoralists are reluctant to pay for such supplies and services that were once freely provided by the government, particularly as herd sizes dwindle. Supplemental forage (e.g., alfalfa) is also a constraint due to limited supplies and high prices. Pastoralists throughout Afghanistan conduct supplemental feeding during winter months when conditions can hinder extensive grazing. Traditional supplements largely consist of local native plants that are cut and carried. In many instances, however, these materials are of low nutritive value and may even be toxic (Jacobs and Schloeder 2012).

In summary, these are all challenges that greatly undermine the prospects for commercialized livestock development. Finding a solution to one problem will not solve the rest and-more importantly - any one intervention is probably doomed to fail unless other, interrelated problems are unaddressed at the same time. Success would require many interventions and forces working in a synergistic fashion.

Ethiopia. The Borana pastoralists of southern Ethiopia largely produce indigenous breeds of dual-purpose cattle (the Boran), Somali hair sheep, East African goats, and dromedary camels (Coppock 1994). All of these breeds are well adapted to the local semiarid environments and all are increasingly in demand for domestic and export markets (Desta et al. 2006). Exotic Dorper sheep and Boer goats are being considered by government researchers as candidates for crossbreeding programs to upgrade the size and productivity of indigenous stock, but it is doubtful that local management systems can sustain improved crossbreeds (Coppock, personal observation). In terms of cattle, there has been a long-term concern by government that the genotype of the Boran has been gradually undermined by crossbreeding 
with inferior stock from the adjacent southern highlands. This occurs when pastoralists actively trade for breeding cows when they build their herds during postdrought recovery periods (Coppock 1994). Government researchers endeavor to have Boran breeding bulls on government ranches to provide breeding capacity to help maintain local gene pools, but the strategy has not been widely implemented (Coppock, personal observation). A process of herd diversification is also being observed where camels are increasing relative to cattle in some regions (Coppock, unpublished data). This probably reflects adaptation to climate change, where camels are better suited to warmer, drier weather, an increased market value for camels, and the ability of camels to supply milk during dry periods when compared to cattle. Camel milk, however, is inferior to cow milk for making butter (Coppock 1994).

As in Afghanistan, the trend for most pastoralists in southern Ethiopia is also to sell a higher proportion of their livestock inventory to meet cash needs; this is due to a rising human population relative to livestock and increasing demand for non-pastoral goods. In the past decade there has been some improvement in value chain development with respect to the finishing of range-bred stock, but this varies greatly with terminal market destination (Desta et al. 2006). Livestock health interventions remain as a significant constraint; outbreaks of highly contagious diseases in the Greater Horn can still result in export trade bans. While livestock marketing and animal health remain as significant challenges in southern Ethiopia, evidence from recent participatory rural appraisals indicates that neither ranks as highly as the need for improved water access or expanded human services (Coppock et al. 2014).

Southern Ethiopia is indeed now better connected to global livestock markets, and there has been a surge in pastoral livestock marketing in the past decade (Desta et al. 2006). Communications have improved as a result of rapid adoption of mobile phone technology (Coppock, personal observation). Producer and marketing cooperatives have been recently formed. New questions have emerged, however, namely which segment of pastoral society, the wealthy minority or other strata, is best poised to benefit from further improvements in livestock marketing. And if wealth is further concentrated via marketing profits, what does this imply for concentrating access to communal forage and water resources that may be increasingly used to produce more animals for commercial, rather than subsistence, purposes?

Sahel. In the Sahel, active marketing of livestock is long-standing with an emphasis by herd managers to develop more breeding herds and flocks, with sales dominated by male cattle, sheep, and goats. The Sahel harbors a large diversity of livestock breeds. Cattle are dominated by zebu breeds such as the Gobra, Bororo, Azaouak, and White Fulani as well as a few trypanosomiasisresistant taurine breeds such as the Kuri and Ndama. Most sheep are thin-tailed hair breeds with a couple wool-bearing breeds (Macina, Arara). Goats become more prevalent in general with increased aridity, although dwarf goats occur in subhumid locations. Crossbreeding efforts to improve indigenous stock were initiated during the colonial era, but crossbred animals have not been sustained in most of the Sahelian region. There has been some recent success, however, 
with crossbreeding programs in peri-urban dairy systems (Hiernaux, personal observation).

Offtake fractions of herds are higher among poorer households with the prices of animals shaped by the timing of sale in relation to season and the drought cycle as well as location of the sale with respect to competitive markets (Turner and Williams 2002). The shift in livestock ownership away from livestock specialists, as well as the expansion of the urban markets, has led to a reorientation of marketing toward the sales of small ruminants (especially sheep) for meat; this particularly occurs on Islamic holidays (Manoli et al. 2014). For these markets, there is evidence for the stratification of livestock production with the raising of small ruminants in the more arid north with subsequent fattening to the south and in peri-urban areas (Amanor 1995). Mobile phones have played an important role in facilitating the trekking of livestock and the distribution of market information (i.e., price and sales volume). Development initiatives have generally focused on the promotion of livestock fattening, livestock market infrastructure, and expansion of the availability of market information via mobile phones.

Mongolia. For Mongolia during the collective era, livestock husbandry was professionalized, and substantial effort was invested in breeding programs and livestock improvement. There were both positive and negative elements to this. One of the lessons learned was that local breeds were often best adapted to Mongolia's harsh conditions, and attempts to "improve" them with more productive animals from western European stock were largely unsuccessful, especially considering species like dairy cattle.

Following the transition to a market economy, combined with growing concerns about increasing livestock populations and overgrazing, the emphasis has been on incentives for herders to increase animal quality and decrease the quantity (MMAI 2010; World Bank 2013a). In the early 1990s these proposals were largely rejected by herders, but since the most recent winter weather catastrophe in 2009-2010, many herders appear genuinely interested in this approach and much more receptive to making these types of changes. Under the collective system all livestock that were not for personal consumption belonged to the state and were part of the government procurement apparatus.

With the transition out of collectives, herders were faced for the first time with the challenge of selling their livestock and livestock products on an open market. Initially, many opportunistic itinerant traders took advantage of this situation, and terms of trade for isolated rural herders were often exploitive. With time, herders became savvy, and many began to take their products to market directly, either to the provincial markets or the capital city; this allowed producers to obtain a better price for their products and also to purchase needed supplies more cheaply. However, this is not possible for all herders.

All Mongolian herders sell live animals for meat, primarily sheep and goats. Most sales and slaughter take place in the fall. A smaller number of herders who are located near settlements and urban centers sell dairy products in local markets, primarily during the summer. Fueled by international demand, cashmere goat hair has become the cash crop of Mongolian herders, and herd compositions through- 
out Mongolia reflect the demand for this high-value livestock product, which is combed and sold in the spring.

Both development organizations and the Mongolian government have attempted to encourage herders to form marketing cooperatives in order to make marketing more efficient and profitable, but many of these efforts are still in their infancy (MMAI 2010; World Bank 2013a). In addition, there are many barriers to marketing livestock products that perish quickly. At the national scale, Mongolia's slaughterhouses do not meet standards for international export to most countries, limiting the potential for foreign markets (Zoljargal 2013).

Altiplano. For the Altiplano, the traditional livestock at higher elevations have been comprised of native camelid species (i.e., llama, alpaca, and vicuña). Llamas have been traditionally used for portage and meat, while alpaca and vicuña have been primarily used for high-quality fiber production. Dual-purpose cattle and hair sheep at lower elevations in the rangelands of rural areas are dominated by unimproved criollo breeds descended from stock brought by the Spanish Conquistadors.

Market expansion in the vicinity of the large urban centers of highland Bolivia has been important in providing incentives for agro-pastoralists, in particular, to crossbreed cattle and sheep to increase milk and wool production, respectively (Markowitz and Valdivia 2001). Crossbreeding programs of criollo cattle with Holsteins and criollo sheep with Corriedale, Targhee, and Merino have now been sustained for over 20 years. A particularly strong demand for milk has been a major driver for rural development (Valdivia 2004). Public-private partnerships have helped catalyze change via producer training and technology adoption programs. Synergisms have also occurred due to timely improvements in road infrastructure and rural extension. In contrast to the growing dairy industry, however, the fiber industry has not been innovative. Fiber markets tend to be dominated by a few, large textile manufacturers that seek to dominate producers; this results in low, fixed prices (Valdivia 1991). As a consequence, camelid production, in general, tends to focus more on meat than fiber, but this has also occurred in response to growing demand for camelid meat (Turin et al. 2010). There are NGOs working with producers to create niche markets for woolen handicrafts, thus undermining the monopoly imposed by the textile industry (Turin, unpublished data).

Mexico. The Mexican government has been actively promoting development of the livestock industry in northern Mexico. This has been in response to challenges of drought and economic uncertainty. Hence, agricultural subsidy programs have been promoted that facilitate the sustained production of food staples in rural areas. In combination with the previously mentioned Constitutional Agrarian Land Reform of 1992, these programs have a large effect in driving changes in land use and land cover. One example is the Direct Support to Rural Areas Program (PROCAMPO) that was launched in 1993 to grant an annual subsidy per unit of land for food grain production (SAGARPA 2009, 2010). Another is the Program of Incentives to Livestock Production (PROGAN), launched in 2003 to provide subsidies for ranchers in support of livestock production, land conservation and restoration, and water development (SAGARPA 2009).

Marked changes in cattle trading patterns between the US and Mexico and changes associated with new US-Mexico cattle and beef trade relationships after 
NAFTA, the Mexican peso devaluation (Peel 1996), fluctuations in US cattle prices, and a continuously increasing domestic livestock market have turned Mexico into a net importer of meat mostly from the US and recently also from Canada (and potentially from South America). While most of the national meat market was once satisfied by grass-fed livestock (Peel 2005), in recent years a change in meat preference by Mexican beef consumers has increased the demand for grain-finished beef. This new consumer pattern has strong implications on the use of arable land, where an increasing demand of grain for feed is competing with food production in a country with a growing human population (Arredondo and Huber-Sannwald 2011). As a nation that is becoming more affluent, beef consumption has been rapidly growing, such that Mexico has turned from a formerly cowcalf exporter to the US to a net importer of grain-finished beef. International cattle markets are operated by large ranchers, while ejido livestock is marketed at the local level.

\subsubsection{Conflict and Crisis Management}

Summary. Conflict - whether in the form of simple arguments among neighbors, banditry, ethnic hostilities, or international warfare - has long been part of the social fabric in the world's rangelands. Rangelands are remote, sparsely populated, and difficult for central governments to police. Rangelands thus provide places where local problems can fester and where rebels or criminal elements can find safe haven. In contemporary times there have been coordinated efforts by government and other stakeholders to help mitigate rangeland conflicts. This is because persistent conflicts can impair social welfare, undermine economic development, and endanger public safety. There has been increasing recognition of the importance of conflict management practices, whereby antagonists are brought together by facilitators in face-to-face settings to problem-solve. Many such approaches have been pioneered in the western USA over the past three decades, and similar efforts have occurred more recently in the developing world. Our six case-study sites vary widely in terms of the scope and severity of social conflicts. The Altiplano and Mongolia are fortunate to have the narrowest spectra of conflicts that are largely focused on land-use competition, while Afghanistan suffers from the widest conflict spectrum that has been incubated by decades of war and ineffectual central governments. It could be hypothesized that the incidence of social conflict should be on the increase across all of our six case-study sites simply as one outcome of more people chasing fewer resources per capita. However, there is no evidence here to support this idea. 


\subsubsection{Pivotal Issues and Conceptual Advances}

Over the past 25 years there has been a growing interest in how to better manage social conflicts that arise from competition among stakeholder groups for access to, or use of, natural resources. While such conflicts have not been confined to one region of the world, the development of conflict management techniques, as grounded in collaborative learning processes, has been focused more in the western US where various user groups-having divergent value systems for natural resources - often collide when using public lands (Cheng et al. 2010; Daniels and Walker 2001). ${ }^{39}$ More collaborative learning differs in significant ways from previous approaches for dealing with policy making, public discourse, and crisis management. Current approaches can include systems thinking and alternative dispute resolution concepts such as social arbitrage. A variety of approaches have evolved (Conley and Moote 2003). The rangelands of the western US have endured numerous "culture clashes" that require problem solving (Huntsinger and Hopkinson 1996). Coordinated resource management (CRM; Cleary and Phillippi 1993) is one approach that has been employed to mediate conflicts among stakeholders sharing watersheds or other communal resources.

Conflicts have long been recognized as a major part of rangeland societies in the developing world; the traditional culture of intertribal cattle raiding in eastern Africa is a notable case in point (Gray et al. 2003). Warfare historically has been an important means for various pastoral groups in Ethiopia to gain access to resources (Coppock 1994). Resource-based conflict has also occurred over hundreds of years in the Andes (Coppock and Valdivia 2001) and central Asia (Weatherford 2004).

Livestock raiding behavior, in particular, can be exacerbated by drought, poverty, firearm proliferation, cultural rivalries, revenge-seeking, and meddling by commercial and political interests (Krätli and Swift 1999). While long a part of the social and ecological fabric in some situations, when raiding is sharply intensified due to a competitive imbalance in weaponry, for example, the survival of entire communities can be jeopardized (Gray et al. 2003). Rangelands in some corners of the developing world are ideal places to generate such problems because they are vast, remote, and difficult to police. They are places where traditional rivalries can fester, insurgents hide, and banditry goes unpunished. ${ }^{40}$ Open conflict can therefore hobble efforts to help pastoral societies make progress in economic development. There is a need to improve how disputes can be better managed in contemporary pastoral societies (Krätli and Swift 1999; Niamir-Fuller 1999).

\footnotetext{
${ }^{39}$ There has also been a groundswell of literature on relationships between social learning and participatory approaches to natural resource management more generally. This literature has emerged from scholars who work in the developing world (Reed 2008).

${ }^{40}$ Our case-study sites, however, exhibit marked variation in the occurrence of conflict or banditry, so this statement is not meant to be generalized for all pastoral situations.
} 


\subsubsection{What Has Been Observed?}

Afghanistan. Afghanistan has historically been a troubled nation in terms of chronic conflicts and civil unrest. In recent times, insecurity due to insurgent and criminal activities has been on the rise since the initial NATO intervention in 2002 (HRW 2006-2014). Ethnic conflict is also on the rise, mostly in terms of revenge acts in response to heinous acts committed in the past. The situation is exacerbated by a weak government having little interest in better managing traditional disputes. Reducing conflict at a local or regional scale has been shown to improve access to resources and build economic ties among pastoralists (Jacobs et al. 2009). Building governance capacity in general is also crucial, but will take time. Training local people in methods for conflict management has been shown to yield impressive results, and hence is a viable approach in the interim (Jacobs 2013).

Ethiopia. The central Borana Plateau of southern Ethiopia is over $600 \mathrm{~km}$ away from the seat of national political power in Addis Ababa. It is thus a relatively remote area in a region buffeted by drought, growing human populations, increasing poverty, firearm proliferation, and tensions arising from political and religious factors (Coppock, personal observation). Local conflicts periodically occur, but they rarely become magnified at larger spatial scales. The relatively peaceful environment is related to (1) a palpable government and security presence; (2) a strong, traditional Oromo culture of peace and acknowledged need for coexistence; and (3) provision of extensive safety net programs in recent years, most notably food aid.

Published research on conflict here remains rare. The southern Ethiopian rangelands share a border with Somalia to the east and Kenya to the south; both countries have been the source of periodic tensions with Ethiopia over the past 50 years, especially Somalia. Ethnic clashes occur between the Boran and their Gabra, Gurre, and Gugi neighbors on the Borana Plateau. Clashes are diverse in terms of causes and effects. Causes are often related to local or regional political issues, while effects can vary from the near-trivial to catastrophic displacement of thousands of people along with the deaths of hundreds. Crisis can be ignited by key events such as a drought (with subsequent intensified competition over natural resources between adjacent groups) or personal confrontations among individuals. The government actively intervenes as an agent for conflict mediation in concert with local officials and traditional tribal leaders. In recent participatory rural appraisals with pastoral leaders on the Borana Plateau, the need to build increased capacity for conflict mediation was noted (Coppock et al. 2014).

Sahel. In the Sahel, livestock herders following a significant fraction of their family's wealth (namely their animals) are vulnerable to various predations while away from their home territory. The military insecurity and widespread banditry in the northern Sahelian region have heightened the dangers faced by herders with evidence that some have changed their movements to reduce their exposure to these risks (de Bruijn and van Djik 1995; Turner et al. 2014). For example, herders in the Dantiandou study area report remaining within their home territory or, when moving north during the rainy season, remaining near larger towns or staying away from insecure rural areas in the far north. This, in turn, can lead to changes in grazing pressures elsewhere with implications for herd productivity and the environment. 
Livestock movements themselves can lead to conflict among herders over pasture and water or with farmers over crop damage or access to water points or travel corridors (Moritz 2006). There is often a strong insider-outsider dynamic to these conflicts with those that are seen as outsiders often in more vulnerable positions due to their more limited connections to local authorities. It is not surprising, therefore, that herders have historically relied on local hosts to mediate with local communities (Heasley and Delehanty 1996). Where formal government authority plays a stronger role relative to customary practices in mediating disputes, these hoststranger relationships are less important, and some herder groups move through areas without developing social ties to local communities.

Mongolia. Mongolia is fortunate not to experience the types of ethnic or political conflict that plague some rangelands of the world. Nevertheless, conflicts between herders over pastoral resources have escalated since privatization (FernándezGiménez et al. 2008). It is unclear whether the trend towards formal communitybased rangeland management organizations will help ameliorate these conflicts (among members of a given group) or potentially exacerbate them (between members and outsiders). The incursion of mining companies and ninja (i.e., artisanal or wildcat) miners into herder's traditional grazing territories is likely to be a more significant source of conflict in the coming years. Already there have been some organized protests by herders, sometimes in alliance with urban environmentalists, and there have been reports of strategic violence against such protesters on the part of mining interests. Herders widely report that they have no voice in decisions about mines and mining (Schmidt, personal communication).

Altiplano. As with Mongolia, social conflict is less prevalent on the Altiplano when compared with the other case-study locations. Conflicts among herders for water and grazing lands are on the increase, however. The major friction of note today is related to growing competition between mining companies and herders for groundwater (Turin, personal observation).

Mexico. In northern Mexico, unequal access to communal and agricultural land among ejidatarios and non-ejidatarios (immigrants to ejidos) causes long-lasting, cross-generational social conflicts in ejidos. This has led to divisions in communities, potentially affecting key issues such as water rights (Martínez-Peña 2012). Drug trafficking in Mexico has had detrimental effects on national security and has particularly affected the sparsely populated north. It is unclear, however, how conflicts associated with drug trafficking have affected local populations or local economies.

\subsection{Future Perspectives}

\subsubsection{Priorities for Applied Research and Outreach}

As rangeland professionals seek to serve rangelands and pastoral peoples in the twenty-first century, an important question is this: What are the emerging priorities for applied rangeland research and outreach in the developing world? To answer 
this question based on their extensive experiences, the coauthors considered the needs of pastoral populations as well as research knowledge gaps and the likelihood of successful, practical outcomes.

Table 17.2 illustrates priorities for applied research and outreach topics as ranked across the six case-study locations. It is important to note that the views embodied in this table are those of developed-world experts, and these are inevitably shaped by bias. The priorities will likely differ from those of pastoralists, development agents, or researchers affiliated with host-country institutions. For example, it is reasonable to expect that pastoralists might emphasize priorities more closely linked to the alleviation of their acute problems. ${ }^{41}$

The seven topics were distilled from a longer original list, and hence the analysis represents rankings based on two levels of resolution. In addition, the case-study sites for northern Mexico and the Altiplano were broken out to represent two very distinct and equally important subpopulations because the experts for these sites felt that the ranks would not be meaningful if lumped together.

It is notable that the rankings within six of the topics were highly variable across the case-study sites (i.e., ranging from a low of 1.1 to a high of 6.2, on average). The one exception, however, was topic 7, "Restore or create new pastoral institutions" (Table 17.2). The rankings for this topic only varied from 5.0 to 7.0. Thus, considered overall, support to pastoral institutions was clearly first, followed by (2) livelihood diversification; (3) livestock and rangeland management (tied); (5) conflict management or mitigation; (6) marketing; and (7) limiting expansion of non-pastoral activities on pastoral lands.

It was also evident from the coauthors that the seven topics are not mutually exclusive. Strengthening pastoral institutions, for example, is also tied to conflict management, control over pastoral lands, pursuit of sustainable markets, and improved rangeland management. Distinctions were also made in the realm of livestock and rangeland research - namely to emphasize ecological sustainability and conservation over an emphasis on increasing productivity and profitability. And there are also instances where a topic could be ranked differently in terms of outreach need versus research gaps, but we consolidated this to try to keep things simpler. Thus, it may be most accurate to consider a final ranking of aggregated topics as follows: (1) pastoral institution building; (2) livelihood diversification; and (3) livestock and rangeland management.

The most successful approaches will thus be increasingly broad and integrative. Such approaches fall within the sphere of building resilience within social-ecological systems (Berkes et al. 2008); Walker et al. 2004) or in a similar context of coupled human and natural systems (Dong et al. 2011). The human dimension also needs to include capacity building for institutions external to pastoral systems that affect pastoral development or resilience-building processes (Dong et al. 2011).

\footnotetext{
${ }^{41}$ See Thurow et al. (2007) concerning survey results for university education in rangeland science as a case-in-point; there was little agreement among professors, ranchers, and agency staff in what the priorities should be.
} 


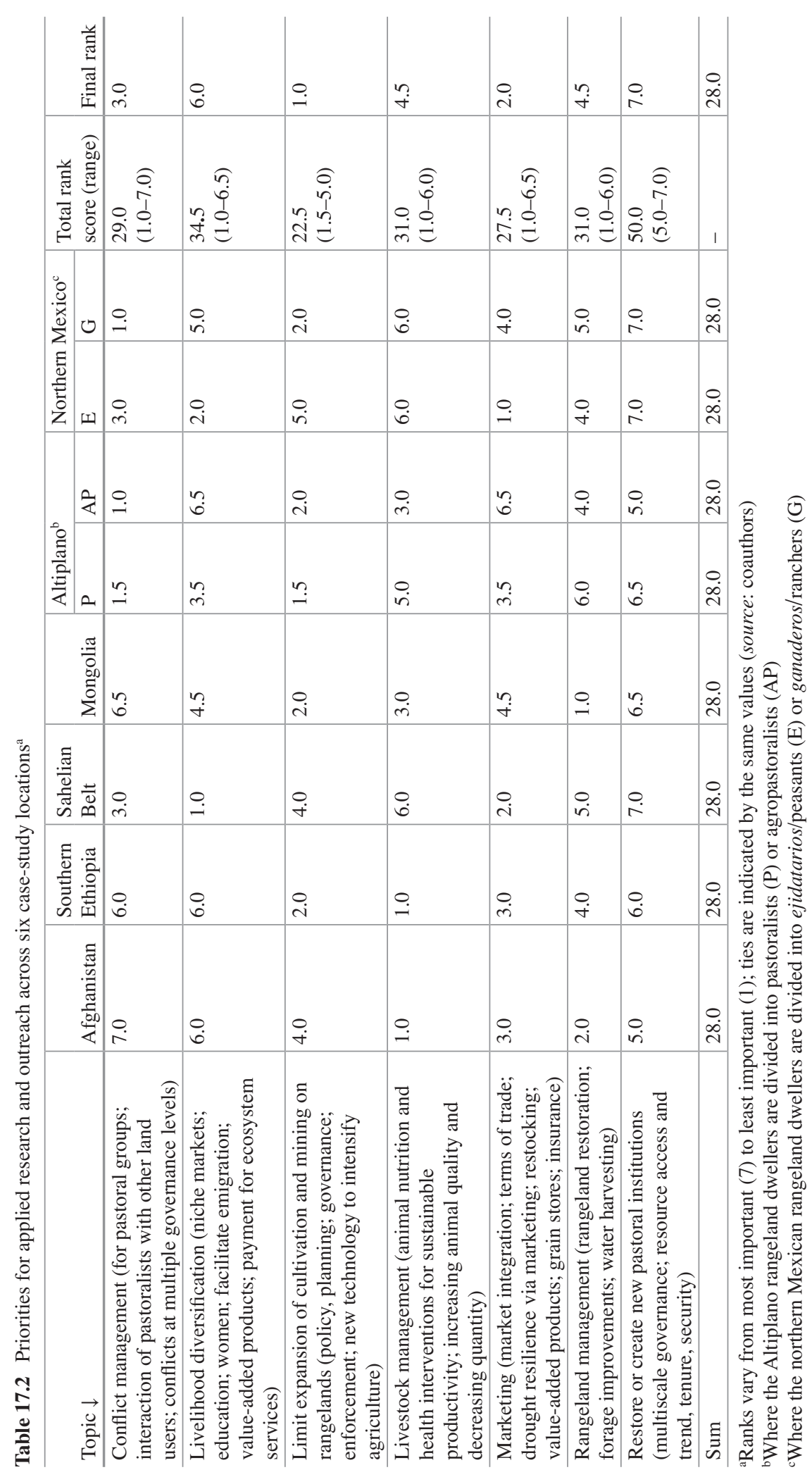




\subsubsection{How Have Our Knowledge Base and Field Activities Changed?}

Our review of the six case-study sites has been limited in breadth and depth, but overall it indicates that a vast amount of new knowledge has been generated during the past 25 years. Over a generation has passed since the publication of seminal, synthetic works on rangeland ecology and management relevant to the developing world. These include efforts by Huss and Aguirre (1974) for Mexico, Penning de Vries and Djiteye (1982) and Le Houérou (1976) for the Sahel, Pratt and Gwynne (1977) for East Africa, as well as Florez and Malpartida (1988) for the Peruvian Andes, and Sandford (1983) for the developing world more broadly. Other books of the 1970s focused on North America - but that ostensibly also had relevance to the developing world - include Stoddart et al. (1975).

When considering the body of work conducted in our case-study sites over the past 25 years - as well as the current priority rankings from Table 17.2 - it is interesting to see how the overall thematic emphasis has changed. Taking the landmark works from the 1970s and 1980s as the baseline, there has been a decided shift from ecology-focused or top-down, technology-driven work to bottom-up, human-oriented work. ${ }^{42}$ Another notable transformation within the human dimension research sphere has been a shift from methods grounded in detached observation of human communities to one of active engagement and collaboration with communities as research partners. Twenty years ago, human-dimensions research almost solely consisted of surveys, interviews, and participant observation - and much of this effort was conducted by cultural anthropologists and economists. Today, there is far greater emphasis on participatory action research, participatory rural appraisal, and stakeholder involvement from a wide array of research angles, to the extent that pastoralists and policy makers are also active members of research teams. Finally, there is another trend to treat some development interventions as experiments with sound experimental designs and impact-monitoring protocols (Coppock et al. 2011).

The ten coauthors of this chapter debated on the scholarly contributions that have most shaped their work over the past 25 years. About 10 works were nominated, and the top 5 are listed in Table 17.3. Prominent among the 5 are pieces related to systems thinking and integrated problem solving on pastoral lands. Most of these works offer different ways to better unify thought with respect to human and ecological processes.

\footnotetext{
${ }^{42} \mathrm{~A}$ similar transition has occurred in the study of US rangelands, although it could be argued that interdisciplinary, human-focused work is relatively stronger today in the developing-country rangeland context than it is in the US. In either case, the transition is obviously more complex than simply "top-down leading to bottom-up." It has been necessary for scientists to first grasp the complexities of how rangelands function in an ecological sense, and then to understand how management can meet the challenge of promoting sustainable resource use. Once management assumes center stage, then so do people.
} 
Table 17.3 Five of the most influential works (in alphabetical order by first author) over the past 25 years as noted by the coauthors ${ }^{\mathrm{a}}$

\begin{tabular}{l|l}
\hline Reference and Google Scholar citations total $^{\mathrm{b}}$ & Justification \\
\hline $\begin{array}{l}\text { Chambers, R. 1994. The origins and practice } \\
\text { of participatory rural appraisal. World } \\
\text { Development 22: 953-969. (Citations }=1814)\end{array}$ & $\begin{array}{l}\text { Provides an overview of a stakeholder-based } \\
\text { field approach that is valuable in analyzing } \\
\text { complex local problems }\end{array}$ \\
\hline $\begin{array}{l}\text { Ellis, J., and D. Swift D. 1988. Stability of } \\
\text { African pastoral ecosystems: Alternate } \\
\text { paradigms and implications for development. } \\
\text { Journal of Range Management 41(6): }\end{array}$ & $\begin{array}{l}\text { Outlined a concept for nonequilibrium } \\
\text { ecosystems whereby vegetation dynamics are } \\
\text { most influenced by climate and less so by } \\
\text { herbivore populations }\end{array}$ \\
\hline $\begin{array}{l}\text { Ostrom, E. 1990. Governing the Commons. } \\
\begin{array}{l}\text { Cambridge University Press. } \\
\text { (Citations=21,122) }\end{array}\end{array}$ & $\begin{array}{l}\text { Classic overview of theory and practice } \\
\text { concerning common-property management } \\
\text { systems. Offers important insights into } \\
\text { community-based management of forage and } \\
\text { water resources }\end{array}$ \\
\hline $\begin{array}{l}\text { Raynaut C. 2001. Societies and nature in the } \\
\text { Sahel: Ecological diversity and social } \\
\text { dynamics. Global Environmental Change 11: }\end{array}$ & $\begin{array}{l}\text { This long-term, multidisciplinary analysis of } \\
\text { decades of monitoring rural systems reveals } \\
\text { driving links among environmental crises, } \\
\text { agricultural dynamics, and social change }\end{array}$ \\
\hline $\begin{array}{l}\text { Reynolds, J., D. Smith, E. Lambin, and } \\
\text { B. Turner. 2007. Global desertification: } \\
\text { Building a science for dryland development. } \\
\text { Science 316: 847-851. (Citations=656) }\end{array}$ & $\begin{array}{l}\text { The Drylands Development Paradigm offers an } \\
\text { excellent framework that urges professionals to } \\
\text { treat rangelands as social-ecological systems } \\
\text { with complex dynamics }\end{array}$ \\
\hline
\end{tabular}

${ }^{a}$ By influential works we refer to works that best reflect systems thinking and integrated problem solving on developing-country rangelands

${ }^{\mathrm{b}}$ As of April 2, 2015. Also Raynaut (2001) is in French as Raynaut C. (ed.), 1997. Sahel: Diversité et Dynamiques des Relations Societies-Nature. Karthala, Paris. 430 pp. $($ Citations $=108)$

\subsection{Summary and Societal Implications of Conceptual Advances}

It is clear that the volume of knowledge concerning developing-world rangelands has markedly grown - and that, overall, the approaches to pastoral development and research have changed. Yet the question remains as to whether the circumstances of life have also changed for the better for rangeland dwellers as a result of increased scientific knowledge and shifting development paradigms. Are rangelands more productive or better managed compared to situations prevailing in 1975? Are people better fed, more empowered, or leading otherwise improved lives? These are important questions, but they can be difficult to answer. ${ }^{43}$

It is tempting, in response to the question above, to say that the overall conditions appear generally worse today when compared to 1975, for example, given decades

\footnotetext{
${ }^{43}$ In this chapter we do not directly tackle issues pertaining to human or livestock health. It is likely that progress has occurred in developing-country rangelands with respect to the reduction of disease epidemics for both livestock and people (Thurow, personal communication).
} 
of violence in Afghanistan, expanding poverty in southern Ethiopia, growing inequities between ranchers and ejidatarios in northern Mexico, and what appears to be a downhill slide in condition and trend for natural resources in most of our casestudy sites. This can be countered, however, by observations in several places that pastoral women are gaining more opportunities, livestock marketing is more prevalent, communications have improved, and access of some populations to public services and political processes is better. And, although conflict persists, some case-study sites have seen peaceful transitions to more democratic systems of government where pastoralists are freer to make their own choices when compared to their lives under dictatorial, totalitarian regimes. It is probably most accurate to say that there has been a mix of failure and progress - perhaps with the former dominating. The process of development and change will always yield winners and losers.

And some may logically argue that the proposition as to whether research and development have led to meaningful changes in developing-country rangelands is unfair. There are many arenas in the world where the progress of humanity, or lack thereof, cannot be attributed to the incremental contributions of researchers or change agents. Academics and others charged with a research mandate rarely also have a mandate to achieve real-world impact on the human subjects they study. Similarly, development agents at the forefront of change are often ill equipped or unmotivated to document impacts they observe. Much that happens therefore goes unrecorded, whether positive or negative. Achieving impact, in any case, is doubly difficult in places such as developing-country rangelands where the residents are often voiceless in their national political discourse, and the natural resources they depend upon have been regarded as having little economic value. It is difficult to promote positive change for marginalized people living on marginalized lands under the best of conditions. Despite all this, it remains quite reasonable that we can celebrate even the small steps in positive directions that have been achieved.

The contributors to this chapter were polled and asked whether they felt that their work had any demonstrable impact on the people or resources in the six case-study sites. The poll results were understandably mixed. There are three instances, however, where there is clear evidence of impact from combined research and development activities. As previously noted, systemic change has also occurred in both the Altiplano and northern Mexico, but such change is very broad scaled and cannot be directly attributable to contributions from our coauthors; thus it will not be detailed further.

For Afghanistan, Schloeder and Jacobs describe their conflict mitigation program that was undertaken from 2008 to $2012 .{ }^{44}$ They trained 560 leaders from 31 provinces in conflict mediation/mitigation methods; these trainees then have proceeded to resolve 3450 conflicts in both farming and herding communities along 5 major migration routes. Over half of these conflicts dealt with access and user rights to land, forage, and water; the remainder was comprised of social conflicts. About 204,600 households were positively impacted by these efforts. The ripple effect continues as of this writing, despite that the project ended in 2012.

\footnotetext{
${ }^{44}$ The Peace Ambassador and Kuchi Shura Programs (http://pdf.usaid.gov/pdf_docs/pa00hwhk. pdf).
} 
For southern Ethiopia and northern Kenya, over 30,000 pastoral and agro-pastoralists were beneficiaries of a capacity-building program focused on poor women. The program was based on action and participatory research and included integrated training for volunteers in collective action principles, micro-finance, small business management, and livestock marketing (Coppock et al. 2011, 2013b). The project officially ended in 2009 , but many graduates of the program continue to be successful today and women's collective action has spread ${ }^{45}$.

For Mongolia, Fernández-Giménez and colleagues have sustained over 20 years of continuous effort in integrated rangeland research and outreach activities. This has resulted in the training of over 230 Mongolians in both ecological and social science research methods. Trainees vary from undergraduate interns to graduate students, postdoctoral fellows, university faculty, and other professionals. The team has organized outreach workshops involving hundreds of additional participants from pastoral communities, government, and nongovernmental organizations to share research results and engage herders and local government in discussions about transforming scientific results into local action and regional policy recommendations. As a result of these activities, the team's research results are sought after and valued by decision makers, and policy makers consider ecological and social theories and evidence when debating rangeland policy reform. In recognition of such efforts, Fernández-Giménez received a national award from the Government of Mongolia ${ }^{46}$. In essence, one of our scientific peers has been recognized for achieving widespread impact in a developing-country rangeland.

It is thus apparent that on-the-ground impact can occur in developing-country rangelands as a result of projects that incorporate research, action, community participation, outreach, or other development-oriented components. Having research as one of the focal points of such projects is crucial for several reasons, but in a practical sense it matters because it increases the likelihood that impacts will be documented and knowledge will be publicized. Lack of easily accessible documentation regarding the lessons learned from pastoral development projects is a major hindrance in knowledge accumulation for eastern Africa (Coppock, personal observation).

Another common thread of impactful projects is the high investment they make in training students, other professionals, and rangeland residents. Formal training in the context of degrees, certificates, diplomas, or workshop exposure has proven to be a wise investment. Those who have achieved advanced degrees, in particular, have tended to fill positions that ultimately have influenced many rangeland management and policy decisions (Cheruiyot et al. 2007). The value of informal training for members of the pastoral community in topics as varied as conflict management, entrepreneurism, and self-advocacy remains underappreciated in many projects; impacts (rather than just outputs) are increasingly assessed by documenting personal empowerment via anecdotal evidence or testimonies (Coppock et al. 2011). Because range-

\footnotetext{
${ }^{45}$ This project was recognized for scientific excellence in 2015 by BIFAD (Board for International Food and Agricultural Development) of USAID.

${ }^{46}$ Recipient of "The Order of the Polar Star" (http://president.mn/eng/newsCenter/viewNews. php?newsId=1872).
} 
land residents have often been deprived of formal education and other opportunities for skill development, they can be at a disadvantage when coping with change that involves their interface with the modern world. This can be referred to as a gap in human development potential. It has long been argued that human, rather than livestock, development should be the priority for rangelands in the developing world (Jahnke 1982).

We also contend that investment in people (i.e., the building of human and social capital), is relatively low risk in these settings because the gap to be filled is vast, and the returns are very likely to be captured and multiplied over long periods of time. For example, parents passing skills and knowledge on to their children. The skills and knowledge include how to better sustain and diversify their livelihoods, how to advocate for themselves to increase their political voice, how to better protect and manage their natural resources, how to better market their livestock, and how to better manage conflicts.

The success of such investments in human capital provides a stark contrast with investments in the ecological resources of developing-country rangelands. Although they can be vital and productive if well managed, technical investments such as improvements in forages, livestock breeds, or water resources are riskier than investments in people, especially in situations that are dominated by exploitation under conditions of open access or weak rangeland governance. Droughts, wildfires, disease epidemics, and similar natural phenomena can also quickly erase some of the technology gains slowly achieved via livestock or rangeland management. Thus, priority investment in the rangeland dwellers themselves is a sound course of action. When rangeland users demonstrate good self-governance and emerging management capacity, technical investments can be appropriately made to support them in achieving their stewardship, social, and economic development goals. In sum, both the social and ecological aspects of rangeland development must ultimately be integrated. It does little good to empower and educate people if there is not a corresponding environment that will allow success. This requires investment in range stewardship and improvements so that people can begin to operationalize what they have learned.

This perspective of a human-centered or human well-being emphasis for future work in developing-country rangelands reaffirms the trends that we have documented for applied research, outreach, and emerging combinations thereof. Despite the enormous challenges that remain, we feel that we are collectively headed in the right direction.

Acknowledgements The coauthors appreciate the various agencies and other donors - too numerous to mention here - that have supported their research and outreach activities. The coauthors are also grateful for the colleagues, graduate students, field staff, and members of pastoral and agropastoral communities who directly contributed to the findings reviewed in this chapter. Tracy Jones is thanked for her editorial assistance on the manuscript. Finally, the coauthors thank David Briske and two peer reviewers for their constructive comments on earlier versions of this material. 


\section{References}

Addison, J., M. Friedel, C. Brown, J. Davies, and S. Waldron. 2012. A critical review of degradation assumptions applied to Mongolia's Gobi Desert. Rangeland Journal 34(2): 125-137. doi:10.1071/rj11013.

Agrawal, A. 2008. The role of local institutions in adaptation to climate change. Paper prepared for the Social Dimensions of Climate Change, Social Development Department. Washington, DC: The World Bank.

Albrow, M., and E. King (eds.). 1990. Globalization, knowledge and society. London, UK: Sage Publications.

Amanor, K.S. 1995. Dynamics of herd structures and herding strategies in West Africa: a study of market integration and ecological adaptation. Africa 65(3): 351-394.

Arredondo, J.T., and E. Huber-Sannwald. 2011. Impacts of drought on agriculture in northern Mexico. In Coping with global environmental change, disasters and security threats: challenges, vulnerabilities and risks, Hexagon Series on Human and Environmental Security and Peace, vol. 5, ed. H. Günter-Brauch et al. Berlin, Heidelberg: Springer.

Barfield, T.J. 2004. Nomadic pastoralists in Afghanistan: reconstruction of the pastoral economy. Washington, DC: Bank Information Center. http://www.bicusa.org/en/ Region. Resources.5.aspx.

Berkes, F., J. Colding, and C. Folke (eds.). 2008. Navigating social-ecological systems: building resilience for complexity and change. Cambridge, UK: Cambridge University Press.

Bonnet, B., and D. Hérault. 2011. Gouvernance du foncier pastorale et changement climatique au Sahel. Revue des questions foncières (Land Tenure Journal) 2: 157-187.

Boserup, E. 1965. The conditions of agricultural growth: the economics of agrarian change under population pressure. Hawthorne, NY: Aldine Publishing Company.

Boserup, E. 1989. Population growth and prospects of development in savanna nations. In Human ecology in savanna environments, ed. D. Harris. London, UK: Academic Press, Inc.

Breckle, S., and M. Rafiqpoor. 2010. Field guide Afghanistan: flora and vegetation. Bonn: Scientia Bonnensis.

Brottem, L. 2013. The place of the Fula: intersections of political and environmental change in western Mali. Dissertation, Department of Geography, University of Wisconsin, Madison.

Buttolph, L., and D.L. Coppock. 2001. Project alpaca: intensified alpaca production leads to privatization of key grazing resources in Bolivia. Rangelands 23(2): 10-13.

Cappelaere, B., L. Descroix, T. Lebel, N. Boulain, D. Ramier, J.-P. Laurent, S. Boubkraoui, M. Boucher, I. Bouzou Moussa, V. Chaffard, G. Favreau, P. Hiernaux, H. Issoufou, E. Le Breton, I. Mamadou, Y. Nazoumou, M. Oi, C. Ottlé, and G. Quantin. 2009. The AMMA CATCH experiment in the cultivated Sahelian area of south-west Niger-investigating water cycle response to a fluctuating climate and changing environment. Journal of Hydrology 375(1-2): 34-51.

Chambers, R., and G. Conway. 1992. Sustainable rural livelihoods: practical concepts for the 21 st century. Discussion paper 296. Brighton, UK: Institute for Development Studies at the University of Sussex.

Chape, S., M. Spalding, and S. Jenkins. 2008. The world's protected areas. UK, Cambridge: United Nations Environment Program - World Conservation Monitoring Centre.

Cheng, A., L. Kruger, and S. Daniels. 2010. "Place" as an integrating concept in natural resource politics: propositions for a social science research agenda. Society and Natural Resources 16(2): 87-104.

Cheng, Y., M. Tsubo, T. Ito, E. Nishihara, and M. Shinoda. 2011. Impact of rainfall variability and grazing pressure on plant diversity in Mongolian grasslands. Journal of Arid Environments 75(5): 471-476. doi:10.1016/j.jaridenv.2010.12.019.

Cheruiyot, S., T. Thurow, and D. Too. 2007. Range science leadership development in Kenya: a continuing legacy of graduate education. Rangelands 29(4): 49-52.

CIRNMA (Centro de Investigacion en Recursos Naturales y Medio Ambiente). 1997. Facing the altiplano's challenge: a perspective of the altiplano and the Andean inhabitants. Ottawa, 
Canada: CIRNMA, CONDESAN (Consorcio para el Desarrollo Sostenible de la Ecorregión Andina), and IDRC (International Development Research Center).

Cleary, C., and D. Phillippi. 1993. Coordinated resource management: guidelines for all who participate, 1 st ed. Denver, CO: Society for Range Management.

Colville, R. 1998. Afghan refugees: is international support draining away after two decades in exile? Refugee 17(4): 6-11.

Conley, A., and M. Moote. 2003. Evaluating collaborative natural resource management. Society and Natural Resources 16(5): 371-386.

Coppock, D.L. 1994. The Borana Plateau of Southern Ethiopia: synthesis of pastoral research, development, and change, 1980-91. Systems study No. 5. Addis Ababa, Ethiopia: International Livestock Centre for Africa.

Coppock, D.L., and S. Desta. 2013. Collective action, innovation, and wealth generation among settled pastoral women in northern Kenya. Rangeland Ecology and Management 66: 95-105.

Coppock, D.L., and C. Valdivia (eds.). 2001. Sustaining agropastoralism on the Bolivian altiplano: the case of San José Llanga. Logan, UT: Department of Rangeland Resources, Utah State University.

Coppock, D.L., I. Ortega, J. Yazman, J. de Queiroz, and H. Alzérreca. 2001. The grazing livestock of San José Llanga: Multiple-species resource use and the management and productivity of sheep. Pages 167-216 (Chapter 5) in Coppock, D.L. and C. Valdivia (eds.) Sustaining Agropastoralism on the Bolivian Altiplano: The Case of San José Llanga. Department of Rangeland Resources, Utah State University, Logan, UT USA. 292 pp.

Coppock, D.L., S. Desta, S. Tezera, and G. Gebru. 2011. Capacity building helps pastoral women transform impoverished communities in Ethiopia. Science 334: 1394-1398.

Coppock, D.L., S. Tezera, S. Desta, M. Mutinda, S. Muthoka, G. Gebru, A. Aboud, and A. Yonas. 2013. Cross-border interaction spurs innovation and hope among pastoral and agro-pastoral women of Ethiopia and Kenya. Rangelands 35(6): 22-28.

Coppock, D.L., S. Tezera, B. Eba, J. Doyo, D. Tadele, D. Teshome, N. Husein, and M. Guru. 2014. Preliminary results for participatory rural appraisals (PRAs) and follow-up investigations at four pastoral associations on the North-central Borana Plateau, Ethiopia. Unpublished report. Logan: Department of Environment and Society, Utah State University.

Corniaux, C., M. Lesnoff, A. Ickowicz, P. Hiernaux, A. Sounon, M. Aguilhon, A. Dawalak, C. Manoli, B. Assani, T. Jorat, and F. Chardonnet. 2012. Dynamique des cheptels de ruminants dans les communes de Téssékré (Sénégal), Hombori (Mali), Dantiandou (Niger) et Djougou (Bénin). ECliS deliverable 3.1, GET, Toulouse. http://eclis.get.obsmip.fr/index.php/eng/ scientificproductions/delivrable.

CRCM (Colloque Régional Conférence Ministérielle). 2013. Declaration de N'Djamena sur la contribution de l'élevage pastoral à la securité et au développment des espaces saharo-sahéliens. N'Djamena, Chad: Colloque Régional Conférence Ministérielle.

Creevey, L.E. 1986. Women farmers in Africa: rural development in Mali and the Sahel. Syracuse, NY: Syracuse University Press.

Daniels, S., and G. Walker. 2001. Working through environmental conflict: the collaborative learning approach. Westport, CT: Praeger Publishers.

Dardel, C., L. Kergoat, P. Hiernaux, E. Mougin, M. Grippa, and C.J. Tucker. 2014. Re-greening Sahel: 30 years of remote sensing data and field observations (Mali, Niger). Remote Sensing of Environment 140: 350-364.

de Bruijn, M., and H. van Djik. 1995. Arid ways: cultural understandings of insecurity in Fulbe society, central Mali. Amsterdam: Thela Publishers.

Del Pozo-Vergnes, E. 2004. De la hacienda a la mundialización. Sociedad, pastores y cambios en el altiplano peruano. Lima: IFEA-IEP.

Delgado, C. 2003. Rising consumption of meat and milk in developing countries has created a new food revolution. The Journal of Nutrition 133(11): 39075-39105.

Delgado, C., M. Rosengrant, H. Steinfeld, S. Ehui, and C. Courbois. 2001. Livestock to 2020: the next food revolution. Outlook on Agriculture 30(1): 27-29. 
Desta, S., and D.L. Coppock. 2002. Cattle population dynamics in the southern Ethiopian rangelands, 1980-97. Journal of Range Management 55: 439-451.

Desta, S., and D.L. Coppock. 2004. Pastoralism under pressure: tracking system change in southern Ethiopia. Human Ecology 32(4): 465-486.

Desta, S., G. Gebru, S. Tezera, and D.L. Coppock. 2006. Linking pastoralists and exporters in a livestock marketing chain: recent experiences from Ethiopia. In Pastoral livestock marketing in Eastern Africa: research and policy challenges, ed. J. McPeak and P. Little. Warwickshire, UK: ITDG Publishing.

DGAHML (Dirección General del Archivo Histórico y Memoria Legislativa). 2003. La tenencia de la tierra en México, año II, núm. 24, Mexico City, Mexico.

Dong, S., L. Wen, S. Liu, X. Zhang, J. Lassoie, S. Yi, X. Li, J. Li, and Y. Li. 2011. Vulnerability of worldwide pastoralism to global changes and interdisciplinary strategies for sustainable pastoralism. Ecology and Society 16(2): 10. http://www.ecologyandsociety.org/vol16/iss2/ art10/.

Ellis, J.E., and D.M. Swift. 1988. Stability of African pastoral ecosystems: alternate paradigms and implications for development. Journal of Range Management 41: 450-459.

Fafchamps, M., and S. Gavian. 1997. Determinants of livestock prices in Niger. Journal of African Economics 6(2): 255-295.

Fafchamps, M., and A. Quisumbing. 2005. Marriage, bequest, and assortative matching in rural Ethiopia. Economic Development and Cultural Change 53(2): 347-380.

FAO (Food and Agriculture Organization of the United Nations). 1973. Energy and Protein Requirements. Report of a Joint FAO/WHO Ad Hoc Expert Committee. FAO Food and Nutrition Series 7. FAO, Rome, Italy. 118 pp.

FAO (Food and Agriculture Organization of the United Nations). 2006. In Afghanistan Country pasture/forage resource profile, O. Thieme, and J. Shuttie ed., 19 pp. http://www.fao.org/ag/ agp/AGPC/doc/Counprof/afgan/afgan.htm.

Feng, S., A.B. Krueger, and M. Oppenheimer. 2010. Linkages among climate change, crop yields and Mexico-US cross-border migration. Proceedings of the National Academy of Sciences of the United States of America 107: 14257-14262.

Fernández-Giménez, M. 1999. Sustaining the steppes: a geographical history of pastoral land use in Mongolia. The Geographical Review 89(3): 315-342.

Fernández-Giménez, M. 2001. The effects of livestock privatization on pastoral land use and land tenure in post-socialist Mongolia. Nomadic Peoples 5(2): 49-66.

Fernández-Giménez, M. 2002. Spatial and social boundaries and the paradox of pastoral land tenure: a case study from post-socialist Mongolia. Human Ecology 30(1): 49-78.

Fernández-Giménez, M., and B. Allen-Diaz. 1999. Testing a non-equilibrium model of rangeland vegetation dynamics in Mongolia. Journal of Applied Ecology 36: 871-885.

Fernández-Giménez, M., and B. Batbuyan. 2004. Law and disorder: local implementation of Mongolia's land law. Development and Change 35(1): 141-165.

Fernández-Giménez, M., B. Batbuyan, and A. Kamiura. 2008. Implementing Mongolia's land law: progress and issues. Final report to the Center for Asian Legal Exchange. Nagoya, Japan: Center for Asian Legal Exchange, Nagoya University.

Fernández-Giménez, M., B. Batkhishig, and B. Batbuyan. 2012. Cross-boundary and crosslevel dynamics increase vulnerability to severe winter disasters (dzud) in Mongolia. Global Environmental Change 22: 836-851.

Fernández-Giménez, M., B. Batkhishig, B. Batbuyan, and T. Ulambayar. 2015. Lessons from the dzud: community-based rangeland management increases adaptive capacity of Mongolian herders to winter disasters. World Development 68: 48-65.

Flores-Ochoa, J. 1976. Uywa Michiq Punarunakuna. Pastoreo de la Puna Andina. Revista Universitaria. Organo de la Universidad de San Antonio Abad del Cusco, 55-83. Cusco, Peru: Direccion Universitaria de Proyeccion Social.

Flores-Ochoa, J., and Y. Kobayashi (eds.). 2000. Pastoreo alto andino. Realidad, sacralidad y posibilidades. Plural Editores. La Paz, Bolivia: Museo Nacional de Etnografia y Folklore-MUSEF. 
Florez, A., and E. Malpartida. 1988. Manejo de praderas nativas y pasturas en la región altoandina del Perú, vols. I and II. Lima: Fondo del Libro, Banco Agrario del Perú.

Fratkin, E., and E. Roth (eds.). 2005. As nomads settle: social, health, and environmental consequences of pastoral sedentarization in Marsabit District, Kenya. New York, NY: Kluwer Academic Publishers.

Gallais, J. 1984. Hommes du Sahel. Espaces-temps et pouvoirs. Paris: Flammarion.

Galvin, K. 2008. Responses of pastoralists to land fragmentation: social capital, connectivity, and resilience. In Fragmentation in semi-arid and arid landscapes: consequences of human and natural systems, ed. K. Galvin, R. Reid, R. Behnke, and N.T. Hobbs. Dordrecht, The Netherlands: Springer.

Galvin, K. 2009. Transitions: pastoralists living with change. Annual Review of Anthropology 38: 185-198.

Gardelle, J., P. Hiernaux, L. Kergoat, and M. Grippa. 2010. Less rain, more water in ponds: a remote sensing study of the dynamics of surface waters from 1950 to present in pastoral Sahel (Gourma region, Mali). Hydrology and Earth System Sciences 14: 309-324.

Garza-Merodio, G. 2002. Frequency and duration of droughts in the basin of México from late 16th century to the mid 19th century. Investigaciones Geograficas, boletin del Instituto de Geografía, UNAM 48: 106-115.

Gray, L., and M. Kevane. 1999. Diminished access, diverted exclusion: women and land tenure in Sub-Saharan Africa. African Studies Review 42(2): 15-39.

Gray, S., M. Sundal, B. Wiebusch, M. Little, P. Leslie, and I. Pike. 2003. Cattle raiding, cultural survival, and adaptability of East African pastoralists. Current Anthropology 44(Suppl.): S3-S30.

Griffin, K. (ed.). 2003. Poverty reduction in Mongolia. Australia: Asia Pacific Press.

Guengant, J.-P., M. Banoin, and A. Quesnel. 2002. Dynamique des populations, disponibilité en terres et adaptation des régimes fonciers: Le cas du Niger, 155p. Rome: Gendreau Francis, Lututala Mumpasi, FAO.

Henriques, G. and R. Patel. 2004. NAFTA, corn, and Mexico's agricultural trade liberalization. America's Program Special Report. Interhemispheric Resource Center, Silver City, NM. http:// www.americaspolicy.org/.

Healy, K. 2001. Llamas, weaving, and organic chocolate: multicultural grassroots development in the Andes and Amazon of Bolivia. Notre Dame: University of Notre Dame Press.

Heasley, L., and J. Delehanty. 1996. The politics of manure: resource tenure and the agropastoral economy in southwestern Niger. Society and Natural Resources 9(1): 31-46.

Hesse, C., S. Anderson, L. Cotula, J. Skinner, and C. Toulmin. 2014. Building climate resilience in the Sahel. London, UK: IIED.

Hiernaux, P. 2012. La dynamique du Cheptel dans la commune de Dantiandou (Niger). ECliS working document, GET, Toulouse. http://eclis.get.obsmip.fr/index.php/eng/scientificproductions/ delivrable.

Hiernaux, P., and M.D. Turner. 2002. The influence of farmer and pastoralist management practices on desertification processes in the Sahel. In Global desertification: do humans cause deserts? ed. J.F. Reynolds and M.D. Stafford-Smith. Berlin: Dahlem University Press.

Hiernaux, P., E. Mougin, L. Diarra, N. Soumaguel, F. Lavenu, Y. Tracol, and M. Diawara. 2009. Sahelian rangeland response to changes in rainfall over two decades in the Gourma region, Mali. Journal of Hydrology 375: 114-127.

Hijmans, R., S. Cameron, J. Parra, P. Jones, and A. Jarvis. 2005. Very high resolution interpolated climate surfaces for global land areas. International Journal of Climatology 25: 1965-1978.

Hilbig, W. 1995. The vegetation of Mongolia. Amsterdam: SBP Academic Publishing.

Holden, S., D.L. Coppock, and M. Assefa. 1991. Pastoral dairy marketing and household wealth interactions and their implications for calves and humans in Ethiopia. Human Ecology 19(1): $35-59$.

Holechek, J., R. Pieper, and C. Herbel. 2011. Range management principles and practices. Upper Saddle River, NJ: Prentice Hall. 
Holloway, G., C. Nicholson, C. Delgado, S. Staal, and S. Ehui. 2000. Agroindustrialization through institutional innovation: transaction costs, cooperatives, and milk-market development in the east African highlands. Agricultural Economics 23(3): 279-288.

Homann, S., B. Rischowsky, and J. Steinbach. 2008. The effect of development interventions on the use of indigenous range management strategies in the Borana Lowlands in Ethiopia. Land Degradation and Development 19: 368-387.

HRW (Human Rights Watch). 2006-2014. World report: Afghanistan. https://www.hrw.org/ world-report-(year)/Afghanistan.

Huber-Sannwald, E., M. Ribeiro, J.T. Arredondo, M. Braasch, M. Martinez, J. Garcia de Alba, and K. Monzalvo. 2012. Navigating challenges and opportunities of land degradation and sustainable livelihood development in dryland social-ecological systems: a case study from Mexico. Philosophical Transactions of the Royal Society B 367(1606): 3158-3177.

Huntsinger, L., and P. Hopkinson. 1996. Viewpoint: sustaining rangeland landscapes: a social and ecological process. Journal of Range Management 49(2): 167-173.

Huss, D., and E. Aguirre. 1974. Fundamentos de Manejo de Pastizales. Monterrey, Mexico: ITESM.

INEGI (Instituto Nacional de Estatística y Geografía e Información). 2002. Sintesis de Información Geográfica del Estado de San Luis Potosi. Aguascalientes, Aguascalientes, Mexico. http:// www.inegi.gob.mx/.

INEGI (Instituto Nacional de Estadística, Geographía e Información). 2007. Censo Agrícola, Gandero y Forestal. México. http://www.inegi.org.mx/est/contenidos/proyectos/Agro/ca2007/ Resultados_Agricola/

IPCC (Intergovernmental Panel on Climate Change). 2013. Climate change 2013: the physical science basis. Summary for policymakers. Fifth assessment report, $36 \mathrm{pp}$.

Jacobs, M.J. 2013. Conflict resolution handbook: lessons and recommendations for Afghanistan, 23 pp. http://cnrit.tamu.peace/pdfs/PEACE_Handbook_web.pdf.

Jacobs, M.J., and C.A. Schloeder. 2012. Extensive livestock production: Afghanistan's Kuchi herders, risks to and strategies for their survival. In Rangeland stewardship in Central Asia: balancing improved livelihoods, biodiversity conservation, and land protection, ed. V. Squires. Dordrecht, The Netherlands: Springer Science and Media.

Jacobs, M.J., I. Naumovski, C.A. Schloeder, and R.M. Dalili. 2009. Empowering Afghan herders to build peace. Research Brief 09-01-PEACE. Global Livestock Collaborative Research Support Program (GL-CRSP). Davis: University of California.

Jacobs, M.J., J.A. Schloeder, and P.D. Tanimoto. 2015. Dryland agriculture and rangeland restoration priorities in Afghanistan. Journal of Arid Lands. doi:10.1007/S40333-015-0002-7.

Jahnke, H. 1982. Livestock production systems and livestock development in tropical Africa, 253 pp. Kiel, Federal Republic of Germany: Kieler Wissenschaftsverlag Vauk.

Kerven, C. 1992. Customary commerce: a historical reassessment of pastoral livestock marketing in Africa. London, UK: Overseas Development Institute.

Keshkamat, S., N. Tsendbazar, M. Zuidgeest, S. Shirev-Adiya, A. van der Veen, and M. van Maarseveen. 2013. Understanding transportation-caused rangeland damage in Mongolia. Journal of Environmental Management 114: 433-444. doi:10.1016/j.jenvman.2012.10.043.

Knips, V. 2004. Review of the livestock sector in the Horn of Africa (IGAD Countries). Livestock Information, Sector Analysis and Policy Branch (AGAL), Food and Agriculture Organization of the United Nations, 39 pp. http://www.fao.org/ag/againfo/resources/en/publications/sector_reports/lsr_IGAD.pdf

Kosgy, I., R. Baker, H. Udo, and J. Van Arendonk. 2006. Successes and failures of small ruminant breeding programs in the tropics: a review. Small Ruminant Research 61(1): 13-28.

Krätli, S. 2007. Cows who choose domestication. Generation and management of domestic animal diversity by WoDaaBe pastoralists (Niger). Dissertation. Brighton, UK: Institute of Development Studies, Sussex University. 
Krätli, S., and J. Swift. 1999. Understanding and managing pastoral conflict in Kenya-a literature review. Report based on work conducted under DFID Contract CNTR 98 6863. Brighton, UK: Institute of Development Studies at the University of Sussex.

Kristjanson, P., A. Krishna, M. Radeny, J. Kuan, G. Quilca, A. Sanchez-Urrelo, and C. LeonVelarde. 2007. Poverty dynamics and the role of livestock in the Peruvian Andes. Agricultural Systems 94: 294-308.

Lane, C. (ed.). 1998. Custodians of the commons: pastoral land tenure in East and West Africa. London, UK: EarthScan.

Larémont, R. 2011. Al Qaeda in the Islamic Maghreb: terrorism and counterterrorism in the Sahel. African Security 4(4): 242-268.

Le Houérou, H.N. 1976. Contribution à une bibliographie écologique des régions arides de l'Afriqueet de l'Asie du Sud Ouest. In C.R. Colloque Désertification au Sud du Sahara, 170211. Nouvelles edit. Dakar/Abidjan: Afri.

Leduc, C., G. Favreau, and P. Schroeter. 2001. Long-term rise in a Sahelian water-table: the continental terminal in south-west Niger. Journal of Hydrology 243(1-2): 43-54.

Leighton, J. 2013. Shifting livelihoods: trends of pastoralist drop-out and rural to urban migration. Unpublished report, save the children-Japan. Ulaanbaatar, Mongolia.

Leisher, C., S. Hess, T. Boucher, P. van Beukering, and M. Sanjayan. 2012. Measuring the impacts of community-based grasslands management in Mongolia's Gobi. PLoS One 7(2). doi:e30991, doi:30910.31371/journal.pone.0030991.

Lesnoff, M., C. Corniaux, and P. Hiernaux. 2012. Sensitivity analysis of the recovery dynamics of a cattle population following drought in the Sahel region. Ecological Modelling 232: 28-39.

Liu, Y., J. Evans, M. McCabe, R. de Jeu, A. van Dijk, A. Dolman, and I. Saizen. 2013. Changing climate and overgrazing are decimating Mongolian steppes. PLoS One 8(2). doi:e5759910.1371/ ournal.pone.0057599.

Long, S.P., E.A. Ainsworth, A.D. Leakey, J. Nösberger, and D.R. Ort. 2006. Food for thought: lower-than-expected crop yield stimulation with rising $\mathrm{CO}_{2}$ concentrations. Science 312: 1918-1921.

Manoli, C., V. Ancey, C. Corniaux, A. Ickowicz, B. Dedieu, and C.H. Moulin. 2014. How do pastoral families combine livestock herds with other livelihood security means to survive? The case of the Ferlo area in Senegal. Pastoralism: Research, Policy and Practice 4: 3. http://link. springer.com/article/10.1186/2041-7136-4-3\#page-1.

Manzano, M.G., J. Navar, M. Pando-Moreno, and A. Martinez. 2000. Overgrazing and desertification in northern Mexico: highlights for the northeastern region. Annals of Arid Zone 39(3): 285-304.

Markowitz, L., and C. Valdivia. 2001. Patterns of technology adoption at San José Llanga: lessons in agricultural change. In Sustaining agropastoralism on the Bolivian Altiplano: the case of San José Llanga, ed. D.L. Coppock, and C. Valdivia. Logan, UT: Utah State University, Department of Rangeland Resources.

Martens, P. 2006. Sustainability: science or fiction? Sustainability: Science Practice and Policy 2(1): 36-41.

Martínez-Peña, R. 2012. El manejo de los ecosistemas semiáridos del Altiplano Potosino en el context del desarrolllo sostenible. Doctoral thesis, Instituto Potosino de Investigación Científica y Tecnológica, CONACYT.

Marty, A. 1993. La gestion des terroirs et les éleveurs: un outil d'exclusion ou de négociation? Revue Tiers Monde 34(134): 329-344.

McPeak, J., and P. Little (eds.). 2006. Pastoral livestock marketing in eastern Africa-research and policy challenges. Warwickshire, UK: Intermediate Technology Publications.

Meyers, N., and J. Kent. 2004. The new consumers: the influence of affluence on the environment. Washington, DC: Island Press.

Ministerio de Desarrollo Rural y Tierras. 2012. Compendio Agropecuario, Observatorio Agroambiental y Productivo. Compendio 2012. Estado Plurinacional de Bolivia. www.agrobolivia.gob.bo/compendio2012/index.html\#. Accessed 28 Feb 2015. 
MMAI (Mongolian Ministry of Agriculture and Industry). 2010. Mongolian National Livestock Program.

MNSO (Mongolian National Statistical Office). 2012. National livestock census data. http:// en.nso.mn/. Accessed from the NSO website.

Mohmand, A. 2012. The prospects for economic development in Afghanistan: reflections on a survey of the Afghan people, part 2 of 4. The Asia Foundation, Occasional Paper, No. 14, June.

Moritz, M. 2006. Changing contexts and dynamics of farmer-herder conflicts across West Africa. Canadian Journal of African Studies 40(1): 1-40.

Moya, E., and J. Torres. 2008. Familias alpaqueras enfrentando al cambio climático. Lima: Soluciones Prácticas-ITDG.

NAFTA (North American Free Trade Agreement) Commodity Supplement. 2000. Market and trade economics divison. Economic Research Service, United States Department of Agriculture, WRS-99-IA.

Niamir-Fuller, M. 1999. Managing mobility in African rangelands. London, UK: Intermediate Technology Publications.

Nicholson, S. 2013. The West African Sahel: a review of recent studies on the rainfall regime and its interannual variability. ISRN Meteorology. doi:10.1155/2013/453521.

Nixson, F., and B. Walters. 2006. Privatization, income distribution, and poverty: the Mongolian experience. World Development 34(9): 1557-1579.

Nolte, E. (ed.). 1990. Tecnología y cultura en la producción alpaquera. Cusco: CISA/PAL.

NRVA (National Risk and Vulnerability Assessment). 2008. A national risk and vulnerability assessment 2007/8: a profile of Afghanistan. European Union and the Icon Institute. http:// ec.europa.eu/europeaid/where/asia/documents/afgh_nrva_2007-08_full_report_en.pdf.

Odhiambo, Z. 2007. A call to action: conserving livestock diversity. New Agriculturist. http:// www.new-ag.info/en/developments/devItem.php?a=295.

OEA (Organización de los Estados Americanos). 1996. Diagnostico Ambiental del Sistema Titicaca-Desaguadero-Poopo-Salar de Coipasa (Sistema TDPS) Bolivia-Perú. Washington, DC, USA: OEA.

Olsson, L., L. Eklundh, and J. Ardo. 2005. A recent greening of the Sahel-trends, patterns and potential causes. Journal of Arid Environments 63: 556-566.

Orlove, B. 1980. Andean peasant economics and pastoralism. Small Ruminant CRSP. Columbia: Department of Rural Scoiology, University of Missouri.

Ostrom, E. 1990. Governing the commons: the evolution of institutions for collective action. Cambridge, UK: Cambridge University Press.

Peel, D. 1996. U.S. and Mexican cattle and beef trade. Paper presented at NAFTA and Agriculture: Is the Experiment Working? A Tri-National Research Symposium, San Antonio, TX, November $1-2$.

Peel, D. 2005. The Mexican cattle and beef industry: demand, production and trade. Western Economics Forum 4(1): 14-18.

Peel, D., K. Mathews, and R. Johnson. 2011. Trade, the expanding Mexican beef industry, and feedlot and stocker cattle production in Mexico. LDP-M-206-01. USDA Economic Research Service.

Penning de Vries, F., and M. Djiteye (eds.). 1982. La productivité des pâturages sahéliens, une étude des sols, des végétations et de l'exploitation de cette ressource naturelle. Nederlands: Pudoc, Wageningen.

Perramond, E.P. 2008. The rise, fall, and reconfiguration of the Mexican Ejido. The Geographical Review 98: 356-371.

Perramond, E.P. 2010. Political ecologies of cattle ranching in northern Mexico. Tucson, AZ: The University of Arizona Press.

Piñeda-Martínez, L.F., N. Carbajal, and E. Medina-Roldán. 2007. Regionalization and classification of bioclimatic zones applying principal components analysis (PCA) in the central-northeastern region of México. Atmósfera 20: 133-145.

Pratt, D.J., and M.D. Gwynne. 1977. Rangeland management and ecology in East Africa. London, UK: Hodder and Stoughton Ltd. 
Quiroga, J.C. 1992. Agroecological characterization of the Bolivian altiplano. In Sustainable crop-livestock systems in the Bolivian highlands, 123-164, ed. C. Valdivia. Columbia, MO: Unversity of Missouri.

Reed, M. 2008. Stakeholder participation for environmental management: a literature review. Biological Conservation 141(10): 2417-2431.

Reid, R.S., M.E. Fernández-Giménez, and K. Galvin. 2015. Dynamics and resilience of rangelands and pastoral peoples around the globe. Annual Review of Environment and Resources 39: 217-242.

République du Mali. 2001. Charte pastorale du Mali. In Loi No 01-004 du 27 Fevrier, 2001. Bamako, Mali: République du Mali.

Ribeiro-Palacios, M. 2012. Land use change in southern Huasteca, Mexico: Drivers and consequences for livelihood and ecosystem services. Doctorate Thesis, Instituto Potosino de Investigación Científica y Tecnológica, CONACYT.

Safriel, U., Z. Adeel, D. Niemeijer, J. Puigdefabregas, R. White, R. Lal, M. Winslow, J. Ziedler, S. Prince, E. Archer, and C. King. 2005. Dryland systems. In Ecosystems and human wellbeing: current state and trends. Millenium ecosystem assessment. Washington, DC: Island Press.

SAGARPA (Secretary of Agriculture, Livestock, Fishing and Food). 2009. Reglas de Operación de los Programas de la Secretaría de Agricultura, Ganadería, Desarrollo Rural, Pesca y Alimentación. Diario Oficial de la Federación, Martes 29 de diciembre de 2009.

SAGARPA (Secretary of Agriculture, Livestock, Fishing and Food). 2010. Listado de beneficiarios PROCAMPO 1994-2010. http://www.aserca.gob.mx/artman/publish/ article_1424.asp. Accessed 15 August 2010.

Sandford, S. 1983. Management of pastoral development in the third world. London, UK: Wiley.

Sansoucy, R., M. Jabbar, S. Ehui, and H. Fitzhugh. 1995. The contribution of livestock to food security and sustainable development. http://www.fao.org/wairdocs/ilri/x5462e/x5462e04. htm.

Savage, M., W. Dougherty, M. Hamza, R. Butterfield, and S. Bharwani. 2009. Socio-economic impacts of climate change in Afghanistan. Report DFID CNTR 08 850. Oxford, UK: Stockholm Environment Institute.

Schloeder, C.A., and M.J. Jacobs. 2010. Afghanistan livestock market assessment: report on Afghanistan livestock market dynamics, October 2008-2009. Afghanistan PEACE project. http://cnrit.tamu.edu/peace/pdfs/PEACE\%20Livestock\%20Market\%20Synthesis\%20 Report\%20June\%202010\%20web\%20version.pdf.

Schwartz, M.L., and J. Notini. 1994. Desertification and migration. Washington, DC: U.S. Commission on Immigration Reform-Mexico and the United States.

Scoones, I. 1998. Sustainable rural livelihoods: a framework for analysis. In Working paper 72. Brighton, UK: Institute for Development Studies at the University of Sussex.

SEMARNAT (Secretary of environment and natural resources). 2005. El medio ambiente en México 2005: En resumen. Sistema Nacional de Información Ambiental y de Recursos Naturales (SNIARN). SEMARNAT. ISBN 968-817-777-6.

Seré, C., A. Ayantunde, A. Duncan, A. Freeman, M. Herrero, S. Tarawali, and I. Wright. 2008. Livestock production and poverty alleviation-challenges and opportunities in arid and semiarid tropical rangeland-based systems. In Proceedings of the XXI international grasslands congress and the VIII international rangelands congress: multifunctional grasslands in a changing world, vol. 1, 29 June-5 July 2008, Hohhot, China. Guanzhou, China: Guandong People's Publishing House.

Seth, A., J. Thibeault, M. Garcia, and C. Valdivia. 2010. Making sense of 21st century climate change in the Altiplano: observed trends and CMIP3 projections. Annals of the Association of American Geographers 100(4): 835-865.

Singh, N., and J. Gillman. 1999. Making livelihoods more sustainable. International Social Science Journal 51(4): 539-545.

Stafford-Smith, D.M., N. Abel, B. Walker, and F.S. Chapin III. 2009. Drylands: coping with uncertainty, thresholds, and changes in state. In Principles of ecosystem stewardship: resilience- 
based natural resource management in a changing world, ed. F.S. Chapin III, G.P. Kofinas, and C. Folke. New York, NY: Springer.

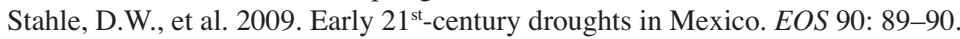

Stoddart, L.A., A.D. Smith, and T.W. Box. 1975. Range management, 3rd ed. New York: McGraw-Hill.

Sullivan, A., and S. Sheffrin. 2003. Economics: principles in action. Upper Saddle River, NJ: Pearson Prentice Hall.

Tabutin, D., and B. Schoumaker. 2004. La demographie de l'Afrique au sud du Sahara des années 1950 aux années 2000. Synthèse des changements et bilan statistique. Population 59(3-4): 521-622.

Tappan, G., M. Sall, E. Wood, and M. Cushing. 2004. Ecoregions and land-cover trends in Senegal. Journal of Arid Environments 59: 427-462.

Thompson, E.F. 2007. Water management, livestock and the opium economy: marketing of livestock case study. Afghanistan Research and Evaluation Unit. http://www.areu.org.af/Uploads/ EditionPdfs/721E-Marketing\%20of\%20Livestock-CS-print.pdf.

Thompson, E., P. Chabot, and I. Wright. 2005. Production and marketing of red meat, wool, skins and hides in Afghanistan: a case study from Kabul, Kandahar, and Kunduz Provinces. Macaulay Research and Consultancy Services and Mercy Corps. http://cnrit.tamu.edu/pdfs/ McCaulay\%20Institute\%20livestock\%20report.pdf. Accessed November 2005.

Thornton, P.K., J. van de Steeg, A. Notenbaert, and M. Herrero. 2009. The impacts of climate change on livestock and livestock systems in developing countries: a review of what we know and what we need to know. Agricultural Systems 101: 113-127.

Thorslund, J., J. Jarsjo, S. Chalov, and E. Belozerova. 2012. Gold mining impact on riverine heavy metal transport in a sparsely monitored region: the upper Lake Baikal Basin case. Journal of Environmental Monitoring 14(10): 2780-2792. doi:10.1039/c2em30643c.

Thurow, T., M. Kothmann, J. Tanaka, and J. Dobrowolski. 2007. Which direction is forward: perspectives on rangeland science curricula. Rangelands 29(6): 40-51.

Toulmin, C. 1987. Drought and the farming sector: loss of animals and post-drought rehabilitation. Development Policy Review 5(2): 125-148.

Toulmin, C. 2009. Securing land and property rights in sub-Saharan Africa: the role of local institutions. Land Use Policy 26(1): 10-19. doi:10.1016/j.landusepol.2008.07.006.

Touré, I. 2010. Caractérisation de l'espace et des ressources des sites du Ferlo. Site de Tessékré. ECliS deliverable 2.3b, GET, Toulouse. http://eclis.get.obsmip.fr/index.php/eng/ scientificproductions/travail.

Turin, C., and C. Valdivia. 2011. Off-farm work in the Peruvian altiplano: Seasonal and geographic considerations for agricultural and development policies. Chapter 10 in: Deveraux, S., R. Sabates-Wheeler, and R. Longhurst (eds). Seasonality, Rural Livelihoods and Development. Earthscan. London, United Kingdom. 320 pp.

Turin, C., and C. Valdivia. 2013. Off-farm work in the Peruvian Altiplano: seasonal and geographic considerations for agricultural and development policies. In Seasonality, rural livelihoods and development, ed. S. Devereux, R. Sabates-Wheeler, and R. Longhurst. Earthscan: London, UK.

Turin C., C. Valdivia, and E. Rivera. 2010. Adaptation of production and commercialization strategies of alpaca fiber and meat to climate and market change in the Peruvian altiplano. Presentation given at the third international symposium of South American Camelids. Arequipa, 8-10 September.

Turner, M.D. 2000. Drought, domestic budgeting, and changing wealth distribution within Sahelian households. Development and Change 31: 1009-1035.

Turner, M.D., and T.O. Williams. 2002. Livestock market dynamics and local vulnerabilities in the Sahel. World Development 30(4): 683-705.

Turner, M.D., J. McPeak, and A.A. Ayantunde. 2014. The role of livestock mobility in the livelihood strategies of rural peoples in semi-arid West Africa. Human Ecology 42: 231-247. doi:10.1007/s10745-013-9636-2. 
UNDP (United Nations Development Program). 2013. Human development report 2013. The rise of the south: human progress in a diverse world. http://hdr.undp.org/en/2013-report. (Human Development Index table is on p.152).

UNHCR (United Nations High Commission for Refugees). 2011. Research studies on IDPs in urban settings. https://s3.amazonaws.com/tdh_e-platform/assets/137/original/WB_UNHCR_ Report_on_Urban_IDPs_finalMay4.pdf?1307851022.

Upton, C. 2008. Social capital, collective action and group formation: developmental trajectories in post-socialist Mongolia. Human Ecology 36: 175-188.

Upton, C. 2009. "Custom" and contestation: land reform in post-socialist Mongolia. World Development 37(8): 1400-1410. doi:10.1016/j.worlddev.2008.08.014.

Upton, C. 2012. Adaptive capacity and institutional evolution in contemporary pastoral societies. Applied Geography 33: 135-141.

USAID (United States Agency for International Development). 2007. Afghanistan food security conditions and causes: a special report by the Famine Early Warning Systems Network (FEWS NET).

Valdivia, C. 1991. Política económica y ganadería extensiva: El caso de ovinos y camélidos en el Perú. Columbia, MO: University of Missouri-Columbia.

Valdivia, C. 2001. Gender, livestock assets, resource management, and food security: lessons from the SR-CRSP. Agriculture and Human Values 18(1): 27-39.

Valdivia, C. 2004. Andean livelihood strategies and the livestock portfolio. Culture and Agriculture 26(1\&2): 19-29.

Valdivia, C., J. Gilles, C. Jetté, R. Quiroz, and R. Espejo. 2003. Coping and adapting to climate variability: the role of assets, networks, knowledge and institutions. In Insights and tools for adaptation: learning from climate variability. Washington, DC: National Oceanic and Atmospheric Administration (NOAA), Office of Global Programs, Climate and Societal Interactions.

Valdivia, C., J. Gilles, and C. Turin. 2013. Andean pastoral women in a changing world: challenges and opportunities. Rangelands 35(6): 75-81.

Valdivia, C., A. Seth, J. Gilles, M. García, E. Jiménez, J. Cusicanqui, F. Navia, and E. Yucra. 2010. Adapting to climate change in Andean ecosystems: landscapes, capitals, and perceptions shaping rural livelihood strategies and linking knowledge systems. Annals of the Association of American Geographers 100(4): 818-834.

Vera, R. 2006a. Country Pasture/Forage Resource Profile-Bolivia. FAO (Food and Agriculture Organization of the United Nations), Rome, Italy. 18 pp. http://www.fao.org/ag/agp/agpc/doc/ counprof/PDF\%20files/Bolivia-English.pdf.

Vera, R. 2006b. Country Pasture/Forage Resource Profile-Peru. FAO (Food and Agriculture Organization of the United Nations), Rome, Italy. 18 pp. http://www.fao.org/ag/agp/agpc/doc/ counprof/PDF\%20files/Peru_English.pdf

Wabnitz, H.-W. 2006. Le code pastoral de la République Islamique de la Mauritanie: Un exemple parfait de législation traditionnelle. In Les frontières de la question foncière: Enchassement social des droits et politiques publiques. Montepellier, France: Institut de recherche pour le développement.

Walker, B. 2002. Ecological resilience in grazed rangelands: a generic case study. In Resilience and the behavior of large-scale systems. Scope Report 60, ed. L.H. Gunderson and L. Pritchard. Washington, DC: Island Press.

Walker, B., C. Holling, S. Carpenter, and A. Kinzig. 2004. Resilience, adaptability and transformability in social-ecological systems. Ecology and Society 9(2): 5. http://www.ecologyandsociety.org/vol9/iss2/art5.

Wane, A., V. Ancey, I. Touré, S. Ndiobe, and A. Diao-Camara. 2010. L'économie pastorale face aux incertitudes. Le salariat au Ferlo (Sahel sénégalais). Cahiers Agricultures 19(5):359-365.

Wang, J., D. Brown, and J. Chen. 2013. Drivers of the dynamics in net primary productivity across ecological zones on the Mongolian plateau. Landscape Ecology 28(4): 725-739. doi:10.1007/ s10980-013-9865-1.

Watts, M.J. 1983. Silent violence: food, famine and peasantry in northern Nigeria. Berkeley, CA: University of California Press. 
Weatherford, J. 2004. Genghis Khan and the making of the modern world. New York, NY: Crown Press.

Wesche, K., K. Ronnenberg, V. Retzer, and G. Miehe. 2010. Effects of large herbivore exclusion on southern Mongolian desert steppes. Acta Oecologica-International Journal of Ecology 36(2): 234-241. doi:10.1016/j.actao.2010.01.003.

Williams, T.O., and B. Spycher. 2003. Economic, institutional and policy constraints to livestock marketing and trade in West Africa. ILRI and FAO/CDI.

Wily, L.A. 2013. Land, people and the state in Afghanistan: 2002-2012. AREU Case Study Series. http://www.areu.org.af/Uploads/EditionPdfs/1303E\%20Land\%20II\%20CS \%20Feb\%202013. pdf. Accessed February.

World Bank. 2013a. Mongolia economic update, 30 pp. Ulaanbaatar: World Bank Group in Mongolia.

World Bank. 2013b. Livestock and agricultural marketing project (LAMP), 73 pp. Project proposal document. Report No. 73827-MN.

Zafar, A. 2007. The growing relationship between China and sub-Saharan Africa: macroeconomic, trade, investment, and aid links. World Bank Research Observations 22(1): 103-130. doi:10.1093/wbro/lkm001. http://wbro.oxfordjournals.org/content/22/1/103.short.

Zant, W. 2013. How is the liberalization of food markets progressing? Market integration and transaction costs in subsistence economies. World Bank Economic Review 27(1): 28-54. doi:10.1093/wber/lhs017.

Zoljargal, M. 2013. Mongolian meat exports decline while prices rise. UB Post, July 16.

Zorogastúa-Cruz, P., R. Quiroz, and J. Garatuza-Payan. 2012. Dinamica de los bofedales en el altiplano peruano-boliviano. Revista Latinoamericana de Recursos Naturales 8(2): 63-75.

Zoundi, J.S., and L. Hitimana. 2008. Livestock and regional market in the Sahel and west Africa. Potentials and challenges. Paris, France: Sahel and West Africa Club/OECD.

Open Access This chapter is distributed under the terms of the Creative Commons AttributionNoncommercial 2.5 License (http://creativecommons.org/licenses/by-nc/2.5/) which permits any noncommercial use, distribution, and reproduction in any medium, provided the original author(s) and source are credited.

The images or other third party material in this chapter are included in the work's Creative Commons license, unless indicated otherwise in the credit line; if such material is not included in the work's Creative Commons license and the respective action is not permitted by statutory regulation, users will need to obtain permission from the license holder to duplicate, adapt or reproduce the material. 